IEA International Civic and Citizenship Education Study 2016

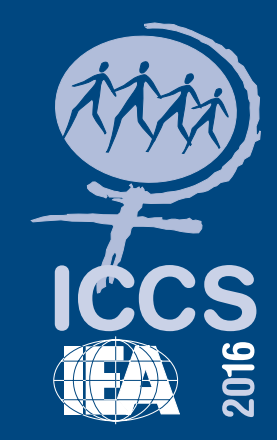

\title{
Assessment Framework
}

Wolfram Schulz

John Ainley

Julian Fraillon

Bruno Losito

Gabriella Agrusti

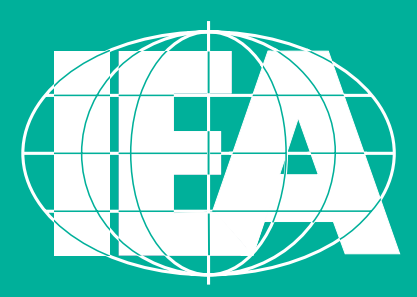




\section{IEA International Civic and Citizenship}

Education Study 2016 Assessment Framework 

Wolfram Schulz • John Ainley • Julian Fraillon Bruno Losito • Gabriella Agrusti

\section{IEA International Civic and Citizenship Education Study 2016 Assessment Framework}


Wolfram Schulz

The Australian Council for Educational Research

Camberwell, Victoria

Australia

\section{Julian Fraillon}

The Australian Council for Educational Research

Camberwell, Victoria

Australia

Gabriella Agrusti

Laboratorio di Pedagogia Sperimentale

Università degli studi Roma Tre

Rome, Italy
John Ainley

The Australian Council for Educational Research Camberwell, Victoria

Australia

Bruno Losito

Laboratorio di Pedagogia Sperimentale

Università degli studi Roma Tre

Rome, Italy

\section{IEA Secretariat}

Herengracht 487

1017 BT Amsterdam, the Netherlands

Telephone: +31206253625

Fax: + 31204207136

e-mail: secretariat@iea.nl

Website: www.iea.nl

The International Association for the Evaluation of Educational Achievement (IEA), with headquarters in Amsterdam, is an independent, international cooperative of national research institutions and governmental research agencies. It conducts large-scale comparative studies of educational achievement and other aspects of education, with the aim of gaining in-depth understanding of the effects of policies and practices within and across systems of education.

Design by Becky Bliss Design and Production, Wellington, New Zealand

ISBN 978-3-319-39356-8

ISBN 978-3-319-39357-5 (eBook)

DOI 10.1007/978-3-319-39357-5

Library of Congress Control Number: 2016948208

(C) International Association for the Evaluation of Educational Achievement (IEA) 2016. This book is published open access.

Open Access This book is distributed under the terms of the Creative Commons Attribution-NonCommercial 4.0 International License (http://creativecommons.org/licenses/by-nc/4.0/), which permits any noncommercial use, duplication, adaptation, distribution and reproduction in any medium or format, as long as you give appropriate credit to the original author(s) and the source, provide a link to the Creative Commons license and indicate if changes were made.

The images or other third party material in this book are included in the works Creative Commons license, unless indicated otherwise in the credit line; if such material is not included in the works Creative Commons license and the respective action is not permitted by statutory regulation, users will need to obtain permission from the license holder to duplicate, adapt or reproduce the material.

The use of general descriptive names, registered names, trademarks, service marks, etc. in this publication does not imply, even in the absence of a specific statement, that such names are exempt from the relevant protective laws and regulations and therefore free for general use.

The publisher, the authors and the editors are safe to assume that the advice and information in this book are believed to be true and accurate at the date of publication. Neither the publisher nor the authors or the editors give a warranty, express or implied, with respect to the material contained herein or for any errors or omissions that may have been made.

Printed on acid-free paper

This Springer imprint is published by Springer Nature

The registered company is Springer International Publishing AG Switzerland 


\section{Foreword}

The 2016 cycle of the International Civic and Citizenship Study (ICCS) is the fourth International Association for the Evaluation of Educational Achievement (IEA) study examining the ways in which young people are prepared to undertake their roles as citizens. The IEA first studied this realm in 1971 as part of the Six Subject Survey in nine countries, which led to the 1999 IEA Civic Education Study (CIVED) conducted in 28 countries. Both studies were explicit recognitions that foundational skills are important, yet that these alone are not sufficient for prospering in today's global society, and in a world that requires an open and more culture-oriented approach, a moral orientation emphasizing human rights, and a focus on social justice and political change.

Recognizing the urgent need for continued international research and evidence on topics related to civic and citizenship education, ICCS 2009 was established as a baseline study for future assessments. With 38 countries participating from around the globe, data gathered from more than 140,000 Grade 8 students and 62,000 teachers in over 5300 schools provided evidence that revealed considerable variation among and within countries about the provision of civic and citizenship education, as well as civic knowledge of students, but also indicated that large majorities of students in all countries strongly endorse democratic values and institutions. The comprehensive core assessment was complemented by three regional modules for Asia, Europe, and Latin America, designed to flexibly recognize local interest and to investigate cultural aspects of civic and citizenship education, particularly in light of the growing impact of the processes of globalization and changing contexts of democracy and civic participation. Finally, a civic and citizenship education encyclopedia, a technical report, and an international database accompanied by a comprehensive user guide allowed the broader research community to use the ICCS data for in-depth analyses.

The 2016 cycle of ICCS will build on the data gathered in ICCS 2009. This publication presents the ICCS 2016 assessment framework, which provides a conceptual underpinning to the measurement of antecedents, processes, and outcomes of civic and citizenship education undertaken in the second cycle of this study. A central aim is to monitor changes in students' civic knowledge and engagement over time by linking the second survey cycle directly to ICCS 2009, allowing the countries that participate in both cycles to monitor trends in civic knowledge and engagement over seven years. Moreover, there is the equally important need to reflect and address new and emerging challenges to improve countries' understanding of issues such as students' role with respect to environmental sustainability, social interactions at school, and the use of new social media for civic engagement. As in the 2009 ICCS survey, the current study allows countries to explore specific topics of common interest, through the establishment of regional modules in Europe and Latin America. Such reliable, comparative evidence and data will enable them to evaluate the strengths of educational policies, both internationally, and within regional contexts, and to measure progress in achieving set goals.

More recently, Global Citizenship Education (GCED) and Education for Sustainable Development (ESD) were identified as critical components of the post-2015 development agenda, expressed as Target 4.7 of the United Nations' Sustainable Development Goals (SDGs) (United Nations, 2015). 
IEA analysts contributed to the UNESCO-led development of indicators for monitoring progress at the global, regional and national levels, and to discussions in the global citizenship education working group of the Learning Metrics Task Force (LMTF). Building on our experience and expertise in studying civic knowledge and citizenship education, the IEA carried out a study and suggested a list of potential indicators for GCED and ESD for post-2015 monitoring. In 2016, UNESCO and the IEA established an official agreement to collaborate in the area of measuring GCED and ESD. We are proud to be involved in this vital global mission and will continue to explore these and related data needs with UNESCO; ICCS is one of the major existing sources of data.

Drawing on an established international network of research organizations, scholars and technical experts, two partner institutions, in cooperation with the IEA, and the national research centers (NRCs), are responsible for the study's organization and implementation. These are the international study center at the Australian Council for Educational Research (ACER), and the associate research center at the Laboratorio di Pedagogia Sperimentale (LPS) at the Roma Tre University in Italy. I thank the research teams for their intellectual leadership, dedication and support: namely, John Ainley, Julian Fraillon, Tim Friedman, and Wolfram Schulz from ACER; and Gabriella Agrusti and Bruno Losito from LPS. My special thanks go to the members of the Project Advisory Committee (PAC), for their thoughtful reviews of the framework and scholarly guidance during the study's development: namely Erik Amnå (Örebro University, Sweden), Cristián Cox (University Diego Portales, Chile), Barbara Malak-Minkiewicz (IEA Honorary Member, The Netherlands), Judith Torney-Purta (University of Maryland, United States), and Wiel Veugelers (University of Humanistic Studies, The Netherlands).

I further thank the key research, management, and support staff at the study's coordinating center at the IEA DPC, namely Falk Brese, Ralph Carstens, Marta Kostek, Hannah Köhler, and Sabine Weber, as well as at the IEA Secretariat, namely Paulína Koršňḱková and Gabriela Noveanu, for their leadership and tireless commitment to the success of the project, and Roel Burgers and Isabelle Gemin. The IEA Publications and Editorial Committee (PEC) suggested improvements to earlier versions of the framework and my thanks go to Seamus Hegarty on behalf of the group, and Gillian Wilson, who edited the document.

Critical funding has been provided by the European Commission Directorate-General for Education and Culture in the form of support grants to the European countries participating in the project and, of course, by the 24 participating countries and education systems.

As always, this IEA study is dependent on the critical input, perseverance, and enthusiasm of the NRCs and their staff. From their collaboration on the development of the framework, to the meticulous management and execution of the study at the national level, their sustained contributions are what ensure a truly successful venture. They are both the foundation and our guides in all the IEA's endeavors.

Dirk Hastedt

EXECUTIVE DIRECTOR IEA 


\section{Contents}

\section{OVERVIEW}

1.1 Purpose of the study 1

1.2 Study background 2

1.3 Recent developments and persisting challenges 3

1.4 Broadening the scope of ICCS 5

$\begin{array}{lll}1.5 & \text { Research questions } & 7\end{array}$

1.6 Study design 9

1.7 Characteristics and structure of the assessment framework 10

2 CIVIC AND CITIZENSHIP FRAMEWORK 11

2.1 Defining civics and citizenship 11

2.1.1 The scope of civics and citizenship in ICCS 2016

2.1.2 The representation of civics and citizenship in the framework $\quad 12$

2.1.3 Mapping assessment domains to the assessment instruments $\quad 13$

2.2 Civic and citizenship content domains 13

2.2.1 Structures and key terms in the ICCS 2016 assessment 13 framework

2.3 Civic and citizenship content domains 15

2.3.1 Content domain 1: Civic society and systems $\quad 15$

2.3.2 Content domain 2: Civic principles 18

2.3.3 Content domain 3: Civic participation 20

2.3.4 Content domain 4: Civic identities 21

2.4 Civic and citizenship cognitive domains 22

2.4.1 Cognitive domain 1: Knowing 23

2.4.2 Cognitive domain 2: Reasoning and applying 23

2.5 Civic and citizenship affective-behavioral domains 24

2.5.1 Affective-behavioral domain 1: Attitudes 24

2.5.2 Affective-behavioral domain 2: Engagement 33

$\begin{array}{ll}2.6 & \text { Mapping items to domains }\end{array}$

3 CONTEXTUAL FRAMEWORK 39

3.1 Contexts for civic and citizenship education 39

3.2 The context of the wider community 42

3.2.1 The context of the educational system 42

3.2.2 The context of the local community and school-community 44 relationships

3.3 The contexts of schools and classrooms 46

3.3.1 School contexts and characteristics 47

3.3.2 Teacher background and their perceptions of schools and $\quad 50$ classrooms

3.3.3 Student perceptions of the context of schools and classrooms $\quad 52$

3.4 The home and peer context 53

3.5 Student characteristics 57 
4 ASSESSMENT DESIGN 59

4.1 The ICCS 2016 instruments 59

4.2 Item types $\quad 60$

4.3 Coverage of framework domains 61

4.4 The ICCS 2016 test design and the described achievement scale 62

$\begin{array}{lll}4.5 & \text { Questionnaire scales } & 63\end{array}$

$5 \quad$ REFERENCES $\quad 67$

6 APPENDICES $\quad 83$

6.1 Appendix A: Institutions and staff 83

6.2 Appendix B: Described proficiency levels $\quad 87$

6.3 Appendix C: Example test items 88 


\section{Overview}

\subsection{Purpose of the study}

The purpose of the International Civic and Citizenship Education Study (ICCS) is to investigate the ways in which young people are prepared to undertake their roles as citizens in a range of countries in the second decade of the 21th century. ICCS 2016 is a continuation of this study, which was initiated in 2009. The first ICCS survey reported on student achievement using a test of conceptual knowledge and understandings of aspects of civics and citizenship. It also collected and analyzed data about student value beliefs, attitudes, behaviors and behavioral intentions relating to aspects of civics and citizenship.

In recognition of the need for continuing research on civic and citizenship education and the widespread interest in the establishment of regular international assessments of civic and citizenship education, the IEA (International Association for the Evaluation of Educational Achievement) decided to undertake a second study cycle of ICCS with a data collection in 2016. The second ICCS survey is intended to respond to enduring and emerging challenges of educating young people in a world where contexts of democracy and civic participation continue to change. New developments of this kind include the increase in the use of social media by young people as a tool for civic engagement, the growing concerns about global threats and sustainable development, as well as spreading recognition about the role of schools in fostering peaceful ways of interaction between young people.

Furthermore, civic competencies can also be viewed as an essential part of a broader skill set required in workplaces, and thus these competencies are not only of interest to political and community leaders, but are also valued by a growing number of employers (Gould, 2011). There is an increased recognition by leaders of the business community that technical skills are important, but that these skills are not sufficient for prospering in today's global economy. Consequently, it is to be expected that employers in the 21st century will be seeking to hire and promote individuals with ample knowledge about significant changes in society, intercultural literacy, ethical judgment, humanitarian values, social responsibility, and civic engagement (OECD [Organisation for Economic Co-operation and Development], 2015).

ICCS 2016 will allow both the measurement of changes over seven years (from 2009 to 2016) and the assessment of additional aspects of civic and citizenship education, including those related to recent developments in a number of countries. The ICCS instruments include a large range of test and questionnaire material from the previous study, which permits the comparison of changes in civic knowledge, attitudes and engagement over time. In addition, new item material was developed to measure aspects that were not included in ICCS 2009. It is expected that future ICCS cycles will take a similar approach, where instruments include both old and new material to permit comparisons over time at national and international levels, as well as the measurement of additional cognitive or affective-behavioral aspects. 


\subsection{Study background}

Prior to ICCS 2016, the IEA conducted three international comparative studies about civic and citizenship education, with a first survey implemented in 1971, a second one in 1999/2000 and third one in 2008/2009 (Schulz, Fraillon, \& Ainley, 2011; TorneyPurta, \& Schwille, 2011).

The first IEA study concerning civic and citizenship education was undertaken in 1971 as part of the Six Subject Study (for a summary, see Walker, 1976). Ten countries participated in this data collection and the report was published in 1975 (Torney, Oppenheim, \& Farnen, 1975). The study included assessments of civic knowledge among 10- and 14-year old students and collected questionnaire-based data from students, teachers and school principals.

The second study, the IEA Civic Education Study (CIVED), was carried out in 1999. It was designed to strengthen the empirical foundations of civic education by providing information about the civic knowledge, attitudes, and actions of 14-year-olds. The study had a twin focus on school-based learning and on opportunities for civic participation outside the school. It focused on three civic-related domains: democracy / citizenship; national identity / international relations; and social cohesion / diversity. The focus on these domains was chosen as being particularly useful to policymakers involved in designing or redesigning curricula and preparing teachers.

CIVED was highly successful in achieving its aims and objectives, and established the evaluation of student outcomes in this learning area as an integral part of international comparative educational research. Phase 1 produced a detailed series of national case studies from the 24 participating countries (Torney-Purta, Schwille, \& Amadeo, 1999). Phase 2 produced two data-rich international reports, the first on the results from the mandatory standard population of 14-year-olds in 28 participating countries (TorneyPurta, Lehmann, Oswald, \& Schulz, 2001) and the second from the 16 countries that surveyed an older population of 16- to 18-year-olds (Amadeo, Torney-Purta, Lehmann, Husfeldt, \& Nikolova, 2002). CIVED findings have had a considerable influence on policy and practice in civic and citizenship education across the world, in both participating and non-participating countries, and have also influenced further (national and international) research in this area (Kerr, Ireland, Lopes, Craig, with Cleaver, 2004; Mellor, \& Prior, 2004; Menezes, Ferreira, Carneiro, \& Cruz, 2004; Reimers, 2007; Torney-Purta, 2009).

ICCS 2009 was built on previous IEA studies of civic education, particularly the CIVED study conducted in 1999 (Amadeo et al., 2002; Torney-Purta et al., 2001), and was also established as a baseline study for future assessments in this learning area. Like its predecessor, it included a student test of civic knowledge and understanding, as well as questionnaires for students, teachers and school principals. However, there were some notable changes regarding the design and scope between CIVED and ICCS 2009:

- The assessment framework was broadened to: (i) have a stronger focus on the motivations for, and mechanisms of, participation associated with citizenship education, (ii) include a wider range of content, and (iii) place a greater emphasis on reasoning and analyzing in addition to knowing.

- The civic knowledge test was administered using a balanced rotated design of seven booklets (including one with CIVED link items) so as to assess a wider range of content and provide for a more extensive coverage of thinking processes. 
- While CIVED collected data from two or more teachers of civic-related subjects in the selected class, the ICCS 2009 teacher survey was directed toward all teachers teaching the target grade in selected schools and thus collected data from a larger and more representative sample at each selected school. This change recognized the influence of the school environment on civic-related learning outcomes.

- To supplement existing published information at country level, additional data on national contexts were collected through a questionnaire completed by national centers drawing on expertise in each of the participating countries.

- For the first time in IEA history, ICCS 2009 established regional modules for three geographic regions (Asia, Europe and Latin America) that included the development of additional student instruments addressing specific aspects relevant to each region.

- An encyclopedia was produced that consisted of detailed descriptions of national contexts, policies and curricula relating to civic and citizenship education for countries that had participated in the study (Ainley, Schulz, \& Friedman, 2013).

The results of this study were reported in a series of IEA publications (Fraillon, Schulz, \& Ainley, 2012; Kerr, Sturman, Schulz, \& Burge, 2010; Schulz, Ainley, Fraillon, Kerr, \& Losito, 2010a, 2010b; Schulz, Ainley, Friedman, \& Lietz, 2011). Analyses of data from ICCS 2009 have also led to numerous reports and publications within countries, as well as reports and papers based on secondary research.

\subsection{Recent developments and persisting challenges}

Since the inception and implementation of ICCS 2009, a number of new global developments that have implications for civic and citizenship education across many countries have occurred:

- The global financial crisis of 2007-2008 and the global recession that followed have had a strong impact on many societies, and underlined the importance of the economy for social cohesion and political stability (Chossudovsky, \& Marshall, 2010; Grant, \& Wilson, 2012; Shahin, Woodward, \& Terzis, 2012). In particular, in those countries that were hit hardest by recession, budget deficits and subsequent austerity measures have been characterized by ongoing dissent about economic policies, high unemployment rates (especially among young people), and the emergent success of protest parties and movements at elections. Since 2011, there has been an economic recovery in a number of countries, while others have experienced a worsening of economic and social conditions. These developments in the economic sphere have consequences for the ways in which citizenship education is envisioned (Kennedy, 2012).

- In many societies, the potential impact of human activity on the environment (in particular on the global climate) as well as the question about the long-term sustainability of development have increasingly become key issues in debates about their future political, social and economic development (Dringer, 2013; IPCC [Intergovernmental Panel on Climate Change], 2014). Under the auspices of the United Nations there have been successive Climate Change Conferences since 1995 in Berlin with recent conferences in 2009 (Copenhagen), 2014 (Lima) and 2015 (Paris). Regard for the environment and its long-term protection are increasingly regarded as integral parts of responsible citizenship with implications for the development of civic and citizenship curricula (Lotz-Sisitka, Fien, \& Ketlhoilwe, 2013). 
- In many countries there are also increasing concerns about how schools can ensure peaceful coexistence within school communities. In particular abuse and bullying of students (by other students and often aimed at various types of social minorities) have become salient issues in discussions about schools and learning environments. The recent movement of large numbers of refugees from the Middle-Eastern region to other (mostly European) countries will most likely increase the need for integrating people from different backgrounds into society. This will also result in challenges to schools in relation to their functioning as socially heterogeneous communities. In many countries, civic and citizenship education includes goals related to the promotion of student engagement with a school community (Fredericks, Blumenfeld, \& Paris, 2004; Willms, Friesen, \& Milton, 2009), fostering a peaceful coexistence and providing students with mechanisms for conflict resolution (Johnson, \& Johnson, 1996; Mickelson, \& Nkomo, 2012).

- Continuing development of information and communications technologies (ICT) has led to an increase in the use of ICT and new social media for civic participation. New social media played an important role in initiating and maintaining support as part of the revolutionary protests in the Middle East, in promoting action on climate change or in organizing protests against austerity measures in the aftermath of the global financial crisis (see for example Kahne, Middaugh, \& Allen, 2014; Milner, 2010; Segerberg, \& Bennett, 2011).

There are also persisting challenges to the study of civic and citizenship education, which have an ongoing impact on civic and citizenship education across participating countries:

- The concept of democracy is intrinsically linked to the notion of citizenship in the sense that democratic processes are generally conceived as dependent on an informed and active citizenry. Most countries around the world consider themselves as democracies, but in many of them there are concerns about the real state of democratic process due to the exclusion of larger parts of the population and the erosion of liberties (Diamond, 2015; Kagan, 2015). Furthermore, in countries with long-standing democratic traditions, there has been evidence of a general downturn in citizenship participation, in particular among younger people (see for example, Dalton, 2002; Putnam, 2000). While education is widely recognized as an important tool for fostering democratic citizenship (Naval, Print, \& Veldhuis, 2002), there are different approaches to citizenship education, which may depend on the underlying basic conceptions of democracy. For example, Westheimer and Kahne (2004) distinguished promoting personal responsibility, active participation, and justice orientation as different approaches in this learning area, and Veugelers (2007) identified adapted, individualized and critical-democratic orientations in civic and citizenship education.

- Increasing globalization continues to influence debate about citizenship education because it challenges traditional notions of citizenship (which have been linked to the nation state), and it has led to supra-national concepts of (global) citizenship and new forms of experiences with citizenship across borders as a result of migration (Brodie, 2004; O'Sullivan, \& Pashby, 2008; Reid, Gill, \& Sears, 2010; Schattle, 2012; Torres, 2002). Based on research among teachers, Veugelers (2011) distinguished three different interpretations of global citizenship: an open and more cultureoriented approach, a moral orientation emphasizing cosmopolitism and human rights, and an approach focusing on social justice and political change. 
ICCS 2009 collected a rich data set to support comparative analyses of civic and citizenship education and provided many interesting results. However, given that the age group was 13- to 14-year-olds, there were some limitations on the extent to which their knowledge, perceptions and behaviors could be assessed. The following issues were taken into account in the development and refinement of the instruments for ICCS 2016:

- Results from CIVED and ICCS 2009 showed that students at this age tended to report little inclination to engage in conventional forms of political or civic participation. In particular, expectations of active engagement in politics through parties, trade unions or local elections were generally low and tended to be associated with lower levels of civic knowledge. Therefore, ICCS 2016 places more emphasis on aspects closer to young people's interests and possibilities of engagement when it is measuring students' attitudes, behaviors or behavioral intentions.

- Questions about democratic beliefs tended to be endorsed by overwhelming majorities of students and therefore provided little information about differences in attitudes among young people of this age. Moreover, in the Latin American region, the responses contradicted more general findings about positive responses to statements, such as those endorsing dictatorships provided they bring benefits to society (see Schulz, Ainley, Friedman, \& Lietz, 2011). In ICCS 2016, when asking student about their views on democracy, preference was given to beliefs that were not necessarily prevalent in their society, such as government influence on courts or nepotism.

\subsection{Broadening the scope of ICCS}

The development of a framework for ICCS 2016 needed to take account of recent developments and ongoing challenges. To achieve this, the international project team, in close cooperation with experts and country representatives, identified areas related to civics and citizenship education, which had either gained more attention in recent years or were regarded as relevant, but which were not addressed in great detail in the previous ICCS survey. Each of these areas includes some aspects that were included in ICCS 2009 to a certain degree, but are addressed in a more comprehensive and broader form in the current study. Through this approach, the wider conceptual framework for ICCS is also open to including additional aspects in future cycles.

The following three areas were identified for inclusion, to broaden the scope of ICCS 2016:

- Environmental sustainability in civic and citizenship education: In many societies, the potential impact of human activity on the environment (in particular on the global climate) and environmental sustainability have become key issues in debates about their future political, social and economic development, which is reflected in many international and declarations (see for example UNESCO [United Nations Educational, Scientific and Cultural Organization], 2015). Over the past decades, responsible citizenship has been increasingly viewed as including regard for the environment and its long-term protection, requisite for future sustainable development (Dobson, 2003; Dobson, \& Bell, 2006; Ferreira, 2013; Hayward, 2006), and nowadays many education systems put emphasis on the protection of the environment or education for environmental sustainability in their citizenship curricula (Ainley et al., 2013; Eurydice [Education Information Network in Europe], 2012; Schulz, et al., 2010b). 
- Social interaction at school: Reviews of civic and citizenship education curricula across countries provide evidence that at the outset of the 21st century a large number of countries place emphasis on non-formal aspects of civic learning through participation and engagement or social interaction at schools (Ainley et al., 2013; Eurydice, 2005; Schulz et al., 2010b). More generally, research increasingly recognizes the importance of social learning within schools (Dijkstra, \& de la Motte, 2014; Durlak, Weissberg, Dymnicki, Taylor, \& Schellinger, 2011; Scheerens, 2011). Therefore, ICCS 2016 is designed to include more aspects related to social interaction at school in the survey instruments, in particular items related to relationships within the school community, including those related to conflict and the use of verbal and physical abuse (for example bullying) (Merrell, Gueldner, Ross, \& Isava, 2008; Rigby, \& Smith, 2011; Smith, Morita, Junger-Tas, Olweus, Catalano, \& Slee, 1998).

- The use of new social media for civic engagement: There is growing evidence about the importance of new social media ${ }^{1}$ and the use of such media has been found to have a profound effect on civic engagement among young people (Anduiza, Jensen, \& Jorba, 2012; Bachen, Raphael, Lynn, McKee, \& Philippi, 2008; Banaji, \& Buckingham, 2013; Kahne, Lee, \& Feezell, 2011). Given the further increases in engagement with social media and its relevance for communication on social and political issues since the previous ICCS survey, it was seen as important to explore the use of new social media for civic engagement in greater detail in ICCS 2016.

In addition, two further areas were identified that had been included in previous IEA surveys as deserving more explicit acknowledgement in the ICCS 2016 assessment framework:

- Economic awareness as an aspect of citizenship: Students' economic awareness may be regarded as an important aspect of civic and citizenship education (see for example, Citizenship Foundation, 2013; Davies, 2006, 2015; Davies, Howie, Mangan, \& Telhaj, 2002). It can be conceptualized as a broad awareness of the ways in which economic issues influence citizenship (rather than financial or economic literacy ${ }^{2}$ ). Economic awareness is relevant to civic and citizenship education because economics is a major focus of government, economic conditions provide constraints on some citizenship activities, citizens contribute to the economic well-being of society, and citizens share responsibility for economic problems and remedies.

- The role of morality in civic and citizenship education: Concepts of morality and character are often invoked in relation to outcomes of civic and citizenship education programs (Althof, \& Berkowitz, 2006; Berkowitz, Althof, \& Jones, 2008; Halstead, \& Pike, 2006; Oser, \& Veugelers, 2008). Many countries have moral education programs (often integrated with civic and citizenship education) and moral education is also often regarded as an independent field of study (Ainley et al., 2013; Veugelers, 2011). Therefore, the assessment framework provides scope for explicit representations of morality in the ICCS 2016 instruments.

1 New social media: a collection of online social networking sites and tools (for example, Facebook, Twitter, YouTube) and shared content sites (for example, wikis, blogs, discussion forums) that people use to socially interact and distribute content with other groups of people.

2 An assessment of students' knowledge and perceptions of the economy is difficult given the age of the ICCS 2016 target population (aged 13-14). In CIVED, cognitive items measuring economic literacy were only included in the survey of upper secondary students aged 16 to 18 (see Amadeo et al., 2002). The OECD Programme for Student Assessment (PISA) assessed the financial literacy of 15-year-old students in its 2012 survey cycle (see OECD, 2014a). 


\subsection{Research questions}

The key research questions for ICCS 2016 concern students' civic knowledge, their dispositions to engage, and their attitudes related to civic and citizenship issues, as well as contexts for this learning area. Some of the key research questions are similar to those that were formulated for ICCS 2009. Each general research question (RQ) relates to a subset of specific research questions to be addressed in ICCS 2016.

RQ 1 How is civic and citizenship education implemented in participating countries? This research question is concerned the national contexts for civic and citizenship education and includes the following specific research questions:

(a) What are the aims and principles of civic and citizenship education in each participating country? The analyses will be focused on information from the national contexts survey with references to published sources (for example, national curriculum documents) about the background and intentions behind civic and citizenship curricula in participating countries.

(b) Which curricular approaches do participating countries choose to provide civic and citizenship education? The analyses will have a focus on different types of civic and citizenship education implemented in participating countries and may be based on national contexts survey data, published sources and school survey data.

(c) What changes and/or developments in this learning area can be observed since 2009? The analyses will include only data from countries participating in both ICCS surveys and focus on reforms and changes in the national contexts for civic and citizenship education.

RQ 2 What is the extent and variation of students' civic knowledge within and across participating countries? Analyses to address this research question would primarily focus on student test data supplemented by information collected through the student questionnaire in order to answer the following specific research questions:

(a) Are there variations in civic knowledge associated with student characteristics and background variables? These analyses would investigate the influence of student gender, family characteristics, socioeconomic indicators and other background variables on civic knowledge.

(b) What contextual factors explain variation in students' civic knowledge? Analyses would study the relationship between contextual variables such as home background or school characteristics at different levels with variation in students' civic knowledge.

(c) What changes in civic knowledge have occurred since 2009? These analyses would be limited to those countries participating in both ICCS surveys and require comparable measures of civic knowledge over time.

$R Q 3$ What is the extent of students' engagement in different spheres of society and which factors within or across countries are related to it? This research question is related to indicators of student engagement and encompasses the following specific research questions:

(a) What is the extent and variation of students' civic participation in and out of school? The analyses will focus on student reports on past and current involvement in civic-related activities. 
(b) What beliefs do students hold regarding their own capacity to engage and the value of civic participation? The analyses will focus on student perceptions of civic engagement.

(c) What expectations do students have regarding civicand political participation in the near future or as adults? The analyses will address students' behavioral intentions regarding different forms of civic or political participation.

(d) What changes in student engagement can be observed since 2009? The analyses will include data from those countries participating in both ICCS surveys and engagement indicators included in both studies.

RQ 4 What beliefs do students in participating countries hold regarding important civic issues in modern society and what are the factors influencing their variation? This research question is related to different student affective measures and encompasses the following specific research questions:

(a) What attitudes do students hold toward civic institutions and society? The analyses will address the way students perceive society in general, its rules and institutions.

(b) What are students' beliefs regarding the importance of different principles underlying society? The analyses should focus on students' beliefs about democracy, citizenship and diversity.

(c) What are students' perceptions of their communities and societies? The analyses will be related to students' sense of identity within their (local, national and supra-national) communities and connections with others in society.

(d) What changes in student beliefs can be observed since 2009? The analyses will include only data from those countries participating in both ICCS surveys and affective-behavioral measures included in both studies.

RQ 5 How are schools in the participating countries organized with regard to civic and citizenship education and what is its association with students' learning outcomes? This research question is related to ways schools (within their community) provide for spaces for civic and citizenship education and encompasses the following specific research questions:

(a) What are the general approaches to civic and citizenship education, curriculum, and/or program content structure and delivery?

(b) To what extent do schools in participating countries have participatory processes in place that facilitate civic engagement? The analyses will primarily focus on teacher and school survey indicators regarding the school climate for civic engagement.

(c) To what extent do schools and communities interact to foster students' civic engagement and learning? The analyses will primarily focus on teacher and school survey indicators regarding the schools' interactions with their local communities and opportunities for students' active civic involvement.

(d) How do schools and teachers perceive the role of civic and citizenship education across participating countries? The analyses will address how teachers, principals and policies perceive the role schools and teacher play in preparing young people for citizenship, and to what extent these perceptions have changed since ICCS 2009. 
These research questions played a central role in shaping the design of ICCS 2016 and its instrumentation, and in guiding the development of the assessment framework. Furthermore, they will provide the basis for organizing the reporting of findings from this study.

\subsection{Study design}

Consistent with ICCS 2009, the student population to be surveyed includes students in their eighth year of schooling (on average including students who are approximately 14 years of age). Typically, this will be Grade 8 students, provided that the average age of students at this year level is 13.5 years or above. In countries where the average age of students in Grade 8 is less than 13.5 years, Grade 9 is defined as the target population. In each sampled school, intact classrooms are selected, and all students in a class are assessed for the ICCS 2016 survey.

The definition of the target population of teachers is the same as in the previous ICCS teacher survey. It includes all teachers teaching regular school subjects to the students in the target grade at each sampled school, but is limited to those teachers teaching the target grade during the testing period and employed at school since the beginning of the school year (Zuehlke, 2011). Fifteen teachers are randomly selected from each school participating in the ICCS survey. There is also an international option to ask teachers of civic-related subjects at the target grade additional questions on civic teaching and learning.

An important feature of ICCS 2009 was the establishment of regional modules in Asia, Europe and Latin America (Fraillon et al., 2012; Kerr et al., 2010, 2011; Schulz, Ainley, Friedman, \& Lietz, 2011). The regional modules were composed of groups of countries from the same geographic region, which together administered additional instruments to assess region-specific aspects of civic and citizenship education. ICCS 2016 includes regional instruments for countries in Europe and Latin America. The content of the regional instruments focuses on topics that are not covered in the international survey material and of particular relevance in the countries of the particular geographic region.

The following instruments are administered as part of the ICCS survey:

- An international cognitive student test consisting of items measuring students' civic knowledge and ability to analyze and reason.

- A student questionnaire consisting of items measuring student background variables and student perceptions.

- Regional student instruments consisting of questionnaire-type items. These instruments are only administered in countries participating in the European and Latin American modules.

- A teacher questionnaire, administered to selected teachers teaching any subject in the target grade. It gathers information about teacher background variables and teachers' perceptions of factors related to the context of civic and citizenship education in their respective schools. As in ICCS 2009, participating countries have the option of offering an online administration of this questionnaire.

- A school questionnaire, administered to school principals of selected schools to capture school characteristics and school-level variables related to civic and citizenship participation. As with the teacher questionnaire, the school questionnaire may be completed online in some countries. 
- The national contexts survey, completed online by national center experts, is designed to gather data about the structure of the education systems, the status of civic and citizenship education in the national curricula, and recent developments. The data obtained from this survey will supplement published information sources about countries and their education systems to assist with interpretation of the results from the student, school, and teacher questionnaires, and in describing national contexts for civic and citizenship education.

\subsection{Characteristics and structure of the assessment framework}

The assessment framework provides a conceptual underpinning for the international instrumentation for ICCS 2016 and the development of regional instruments for European and Latin American countries. It should be noted that the assessment framework is a continuation of the ICCS 2009 framework and that some parts remain unchanged. However, while its basic orientation and coverage is consistent with the assessment framework for ICCS 2009 in order to ensure continuity across survey cycles, it has also been refined as well as modified in order to capture new developments in the area of civic and citizenship education. It is designed to have the following characteristics:

- It maintains a high degree of consistency with ICCS 2009.

- It reflects contemporary research findings on civic and citizenship education among students at secondary school (for example, Pancer, 2015).

- It appropriately addresses the needs and interests of participating countries.

- It limits content to aspects that can be adequately measured.

- It aims to include all relevant aspects of content that describe the breadth of civic and citizenship education across participating countries.

- It takes the whole range of contexts within which civic and citizenship education occurs into account.

The assessment framework for ICCS 2016 consists of the following three parts:

- The civic and citizenship framework outlines the aspects to be addressed when measuring cognitive and affective-behavioral constructs related to civic and citizenship education through the student test and questionnaires.

- The contextual framework describes the different context factors that might influence student learning outcomes related to civic and citizenship education, and which are measured through the student, teacher, school and national contexts questionnaires.

- The assessment design provides an overview of the ICCS instruments, the coverage of framework domains, the different item types, the assessment design, and the expected cognitive, affective-behavioral and contextual indices.

Open Access This chapter is distributed under the terms of the Creative Commons AttributionNonCommercial 4.0 International License (http://creativecommons.org/licenses/by-nc/4.0/), which permits any noncommercial use, duplication, adaptation, distribution and reproduction in any medium or format, as long as you give appropriate credit to the original author(s) and the source, provide a link to the Creative Commons license and indicate if changes were made.

The images or other third party material in this chapter are included in the works Creative Commons license, unless indicated otherwise in the credit line; if such material is not included in the works Creative Commons license and the respective action is not permitted by statutory regulation, users will need to obtain permission from the license holder to duplicate, adapt or reproduce the material. 


\section{Civic and Citizenship Framework}

\subsection{Defining civics and citizenship}

\subsubsection{The scope of civics and citizenship in ICCS 2016}

The civic and citizenship framework identifies and defines those aspects of cognitive and affective-behavioral content ${ }^{3}$ that should be considered important learning outcomes of civic and citizenship education. It should be noted that within the context of this framework the term "learning outcomes" is used in a broad way and is not confined to school learning. The way students develop cognitive knowledge and understanding of civics and citizenship, as well as affective-behavioral dispositions towards civics and citizenship, may depend on many factors beyond their learning environment at school (see Amnå, Ekström, Kerr, \& Stattin, 2009; Pancer, 2015; Pancer, \& Pratt, 1999). The factors influencing students' development of these learning outcomes are mapped and described in the contextual framework.

The conception of civic and citizenship education underpinning ICCS 2016 places the central focus on the individual student who is influenced by "agents of socialization" in varied learning environments (Torney-Purta et al., 2001). It reflects a view that learning about civics and citizenship is not limited to instruction in schools but is an outcome from a range of processes that take place in different environments. Young people learn about civics and citizenship through their interactions with a range of significant others and the various communities with which they are associated. This view has continued through the predecessors of ICCS 2016: CIVED 1999 and ICCS 2009. It is a view that has evolved from ecological systems theories (Bronfenbrenner, 2004; Neal, \& Neal, 2013) and theories of situated cognition (Anderson, Greeno, Reder, \& Simon, 2000).

The field of civic and citizenship education includes cognitive aspects of learning as well as the development of attitudes towards aspects of civic life and dispositions to participate actively in the life of communities. One of the important contributions of the IEA studies investigating civic and citizenship education has been the emphasis on the role of cognitive skills in the preparation of young people to fulfill their roles as citizens. IEA studies of civic and citizenship education have recognized that, in order to participate effectively as citizens, young people need to possess a knowledge base and the capacity to reason about the institutions, events, actions and processes that exist in their civil and civic communities, as well as to develop and justify views and attitudes towards those things. In addition it recognizes that, as students come to know about and process cognitive aspects of civics and citizenship, they also develop and refine attitudes to, and dispositions to participate in, civic life. Conversely, as they develop interests in and a propensity to participate in aspects of civic life so they also learn and understand more about key aspects of civics and citizenship.

3 To describe cognitive and affective-behavioral content in general, we use the term "civics and citizenship" in this framework. However, for describing processes, concepts or domains we use "civic and citizenship" (without "s") in conjunction with the corresponding term or object (for example, the "civic and citizenship framework" or "civic and citizenship education").

(C) International Association for the Evaluation of Educational Achievement (IEA) 2016 


\subsubsection{The representation of civics and citizenship in the framework}

The ICCS 2016 Civic and Citizenship Framework is organized around four content domains:

- Content domain 1: Civic society and systems.

- Content domain 2: Civic principles.

- Content domain 3: Civic participation.

- Content domain 4: Civic identities.

Content domains describe areas of civics and citizenship about which individuals may have developed knowledge and understanding, and towards which they may also have developed perceptions and dispositions. Therefore, topics included in each content domain concern cognitive aspects (i.e. how much students know and understand), and perceptions (i.e. how students view them and are willing to act on them).

Cognitive processes may be viewed as (i) remembering or recalling information or processing content in terms of understanding, or (ii) applying an understanding to new situations (see Anderson, \& Krathwohl, 2001). Similar to the structure of cognitive domains in other IEA studies (see for example: Mullis, \& Martin, 2013), two following cognitive domains are identified in the ICCS 2016 framework:

- Cognitive domain 1: Knowing.

- Cognitive domain 2: Reasoning and applying.

This represents a change in terminology from ICCS 2009 for the Cognitive domain 2 due to the observation that the terms "reasoning" and "analyzing" were conceptually quite similar. Substituting "analyzing" with "applying" is proposed to indicate that students should be assessed with regard to their ability to make effective use of their civic knowledge in real world contexts.

Given the central importance of students' attitudes and dispositions to engage in society, the framework includes an affective-behavioral dimension that concerns the attitudes that students develop and their disposition to participate in the civic life of their societies (see Schulz, Losito, \& Kerr, 2011). The framework envisages this dimension as consisting of two major affective-behavioral domains that are identified in the ICCS assessment framework as:

- Affective-behavioral domain 1: Attitudes.

- Affective-behavioral domain 2: Engagement.

The two affective-behavioral domains attitudes and value beliefs described in the ICCS 2009 framework have been consolidated into affective-behavioral domain 1 in 2016. This was done to address concerns about whether the implicit distinction between more enduring and deeply-rooted attitudes from those that are more focused on specific issues and more time-specific was appropriate for adolescents in the age group under study. In the ICCS 2016 framework, the ICCS 2009 affective-behavioral domains behavioral intentions and behaviors were combined, together with dispositions related to civic participation such as interest or self-efficacy, which had been classified as attitudes in the previous study, into the affective-behavioral domain 2 (engagement). It needs to be recognized, however, that recent or past civic-related activities can also be regarded as contextual factors influencing learning outcomes. 


\subsubsection{Mapping assessment domains to the assessment instruments}

The ICCS assessment of the learning outcomes of civic and citizenship education comprises two types of instrument:

- A student test measuring cognitive representations and processes.

- Student questionnaires (international and regional) measuring affective-behavioral variables reflecting attitudes and engagement.

Data from the cognitive test will contribute to further elaboration of the proficiency scale of civic and citizenship knowledge established in ICCS 2009. The content of the scale is derived from the substance of the four content domains as operated on through the two cognitive domains.

Data from the international and regional student questionnaires will be used to articulate constructs pertaining to the two affective-behavioral domains and relating to the substance of the four content domains. The amount and type of assessment information accessed by each instrument will vary across the four content domains.

\subsection{Civic and citizenship content domains}

\subsubsection{Structures and key terms in the ICCS 2016 assessment framework}

\section{Structure of the content domains}

The four content domains of the ICCS 2016 assessment framework share the following structures:

- Sub-domain: This refers to a substantive or contextual component of a content domain. The sub-domains are described if they include sufficient discrete content to warrant individual definition and articulation. This model anticipates some overlap between the sub-domains within each domain.

- Aspect: This refers to specific content regarded as largely situated within a given subdomain.

- Key concept: This refers to concepts and processes common to sub-domains within a given content domain.

In short, each content domain is divided into sub-domains, and each sub-domain consists of one or more aspects. The key concepts can be expressed within the contexts of any of the sub-domains. Figure 2.1 illustrates the structure of the content domains in the ICCS 2016 assessment framework. 
Figure 2.1: The structure of the ICCS 2016 assessment framework content domains

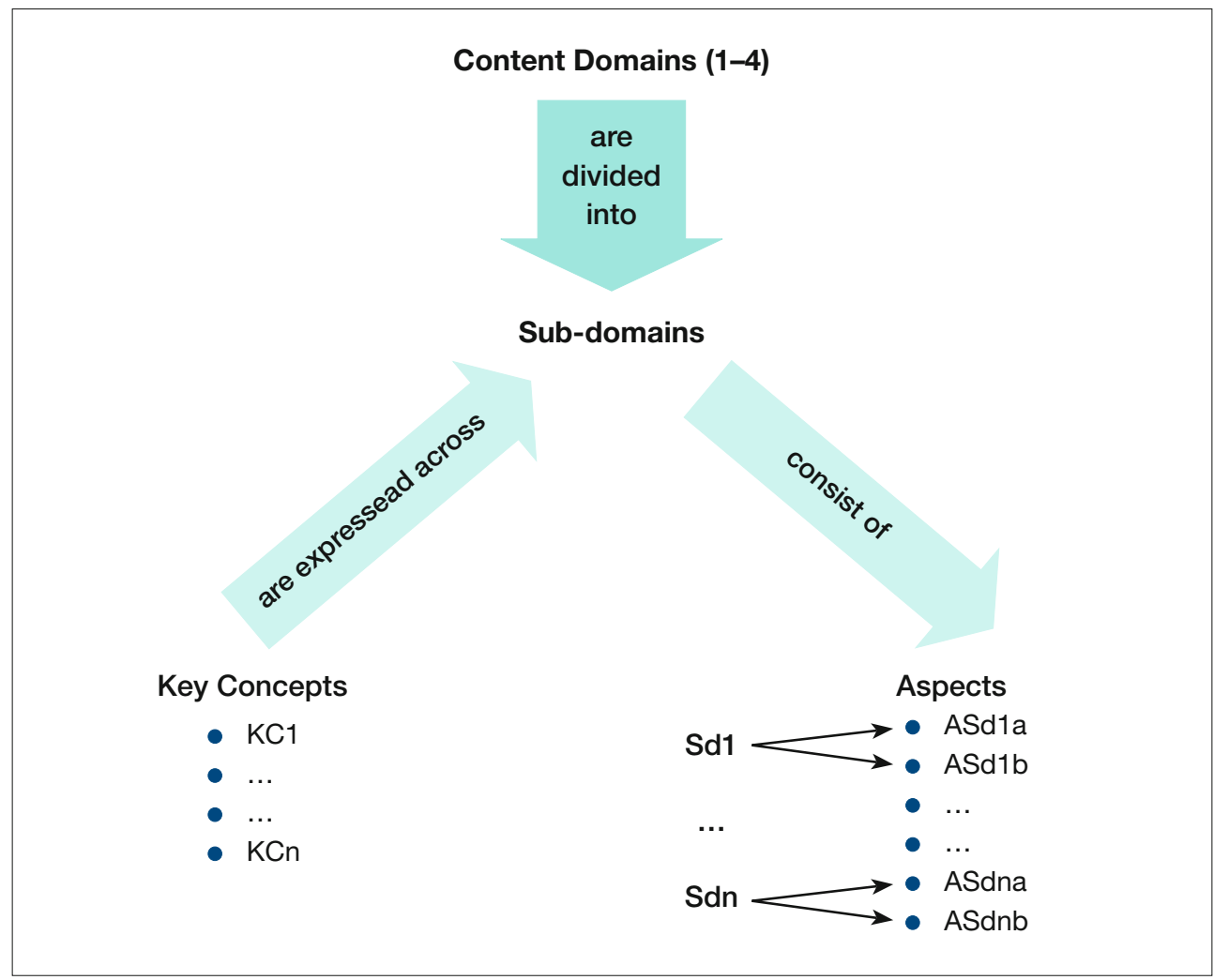

Note: $K C=$ Key concept; $S d=$ Sub-domain; $A S d=$ Aspect.

\section{Structure of the affective-behavioral domains}

The two affective-behavioral domains are described in terms of the types of student attitudes and engagement indicators relevant with respect to the civic and citizenship content domains.

\section{Structure of the cognitive domains}

The two cognitive domains are defined in terms of the cognitive processes that comprise them. This includes the assumption that processes are to be applied to content from within the four civic and citizenship content domains.

\section{Key terms}

The ICCS assessment framework frequently uses a set of key terms. The following definitions of these key terms are those used in this framework. The definitions of many of the terms used in the framework are the subject of ongoing and vigorous academic dialogue. The definitions of the key and domain-specific terms in this framework have been constructed to support consistent understandings of the framework's contents across the broad range of countries participating and interested in ICCS. 
Community A group of people who share something in common (for example, history, values, loyalties, a common goal). In this framework, community membership includes membership based on externally defined criteria relating to the function of the community (such as attending a school as a student) and membership defined by individuals' own belief of their membership (such as through identification with "like-minded" people regarding a political, religious, philosophical or social issue). ${ }^{4}$

Society A community defined by its geographical territory and within which the population shares a common culture (which may comprise and celebrate multiple and diverse ethnic or other communities) and way of life under conditions of relative autonomy, independence, and self-sufficiency.

Citizenship $\quad$ a. The legal status of being a citizen of a nation state or supranational legal community (for example the European Union).

b. The fact of individuals' participation, or lack of participation, in their communities. The term "citizenship," unlike the term "active citizenship," does not assume certain levels of participation.

Civil Refers to the sphere of society in which the shared connections between people are at a broader level than that of the extended family but do not include connections to the state.

Civic Refers to any community in which the shared connections between people are at a broader level than that of the extended family (including the state). Civic also refers to the principles, mechanisms, and processes of decisionmaking, participation, governance, and legislative control that exist in these communities.

\subsection{Civic and citizenship content domains}

The first content domain, civic society and systems, comprises the mechanisms, systems, and organizations that underpin societies. The second domain, civic principles, refers to the shared ethical foundations of civic societies. Civic participation deals with the nature of the processes and practices that define and mediate the participation of citizens in their civic communities (often referred to as active citizenship). The ICCS assessment framework recognizes the centrality of the individual citizen through the fourth content domain civic identities. This domain refers to the personal sense an individual has of being an agent of civic action with connections to multiple communities. Together, these four domains describe the civic and citizenship content to be assessed in ICCS.

\subsubsection{Content domain 1: Civic society and systems}

The content domain Civic society and systems focuses on the formal and informal mechanisms and organizations that underpin both the civic contracts that citizens have with their societies and the functioning of the societies themselves. The three subdomains of civic society and systems are:

- Citizens.

- State institutions

- Civil institutions.

4 Note that a community may still contain a level of diversity.

5 Note that "Global Citizenship" has been included as a concept in content domain 4 (civic identities). 


\section{Citizens}

The sub-domain Citizens focuses on the civic relationships between individuals and groups of citizens and their societies. The aspects of this sub-domain relate to knowledge and understanding of as well as beliefs about:

- Citizens' and groups' assigned and desired roles within their civic society

- Citizens' and groups' assigned and desired rights within their civic society

- Citizens' and groups' assigned and desired responsibilities within their civic society

- Citizens' and groups' opportunities and abilities to engage within their civic society.

\section{State institutions}

The sub-domain State institutions focuses on those institutions central to the processes and enacting of civic governance and legislation in the common interest of the people they represent and serve.

The aspects of this sub-domain are:

- Legislatures/parliaments

- Governments

- Economic structures, mechanisms and conditions

- Supranational/intergovernmental governance bodies

- Judiciaries

- Law enforcement bodies

- National defense forces

- Bureaucracies (civil or public services)

- Electoral commissions.

\section{Civil institutions}

The sub-domain Civil institutions focuses on those institutions that can mediate citizens' contact with their state institutions and allow citizens to actively pursue many of their roles in their societies.

The aspects of this sub-domain are:

- Companies/corporations

- Trade unions

- Political parties

- Non-governmental organizations (NGOs)

- Advocacy groups (for example, pressure, lobby, campaign, special interest groups)

- Traditional media (for example, newspaper, television and radio)

- New social media (for example, web forums, blogs, twitter, Facebook, and text messaging)

- Religious institutions

- Schools

- Cultural organizations. 


\section{Key concepts}
Power/authority Listed together as concepts dealing with the nature and consequences of the right or capacity of bodies or individuals to make binding decisions on behalf of others that these others are then required to accept and to adhere to.

Rules/law

Listed together as the explicit and implicit prescriptions for behavior. Rules are those prescriptions that are not required to be and are therefore not enforced by a sovereign body. Laws are considered to be those prescriptions that are enforced by a sovereign body.

Constitution The fundamental rules or laws of principle governing the politics of a nation or sub-national body.

Governance

The act and the processes of administering public policy and affairs.

Decision-making

The formal and informal processes by which decisions are made within and among civil and state institutions.

Negotiation The processes that underpin and are evident in negotiation, and the use and necessity of negotiation as a means of decision-making.

Accountability The requirement for representatives to answer to those they represent about the representatives' conduct of their duties and use of their powers. Accountability includes the assumption that representatives are able to accept responsibility for their failures and to take action to rectify them.

Democracy The ICCS assessment framework accepts the broadest definition of democracy "as rule by the people." This definition refers both to democracy as a system of governance and to the principles of freedom, equity, and sense of community ${ }^{6}$ that underpin democratic systems and guarantee respect for and promotion of human rights. Both representative democratic systems (such as national parliaments) and "direct democracy" systems (such as through referendums or systems used in some local community or school organizations) can be examined as democratic systems under the definition of democracy used in this framework.

Sovereignty The claim of each individual state/nation to have the ultimate power in making political decisions relevant to that state/nation and recognition that this power underpins the operation and viability of international organizations, agreements, and treaties.

Nation-building The process of developing among the people of a nation some form of a unified sense of national identity, with the aim of fostering long-term harmony and stability. Within the parameters of the ICCS assessment framework, nation-building is assumed to be a dynamic ongoing process in all nations rather than a process associated only with newly independent nations.

Statelessness The circumstances of people who do not have any legal bond of nationality or citizenship with any state. Included in this concept are the causes and consequences of statelessness. 


\begin{abstract}
Franchise/ Voting

The economy

The welfare state

Treaties

Sustainable development

Environmental sustainability

Globalization

Dissent

Listed together, these concepts refer to the rights, responsibilities, and expectations of people to vote in formal and informal settings. These concepts also refer, more broadly, to issues associated with voting and voting processes, such as compulsory and voluntary voting and secret ballots.

Systems governing the production, distribution, and consumption of goods and services within states, including industrial regulation, trade, taxation, and government spending including on social welfare. Economic conditions are both a focus of civic decisions as well as a key aspect of the environment in which decisions about other policies are made.

The role of a government in providing for the social and economic security of its people through support such as health care, pensions, and social welfare payments and benefits.

Binding agreements under international law entered into by eligible bodies such as states and international organizations.

Development that meets the needs of the present without compromising the ability of future generations to meet their own needs. Factors that can be considered in terms of sustainable development include environmental protection, economic development, social equality, and social justice.

A state in which demands placed on the natural world can be met without negatively impacting on the natural world or reducing its capacity to support human life.

The increasing international movement of commodities, money, information, and people; and the development of technology, organizations, legal systems, and infrastructures to allow this movement. The ICCS assessment framework acknowledges that a high level of international debate surrounds the definition, perceptions, and even the existence of globalization. Globalization has been included in the framework as a key concept for consideration by students. The definition is not a statement of belief about the existence or merits of globalization.

In democratic societies, dissent is a central notion that allows for voicing opposition to, expressing disagreement with, or standing apart from, the policies or decisions of the governing body.
\end{abstract}

\title{
2.3.2 Content domain 2: Civic principles
}

The content domain 'Civic principles' focuses on the shared ethical foundations of civic societies. The framework regards support, protection, and promotion of these principles as civic responsibilities and as frequently occurring motivations for civic participation by individuals and groups. The domain consists of four sub-domains:

- Equity

- Freedom

- Sense of community

- Rule of law. 


\section{Equity}

The sub-domain Equity focuses on the principle that all people have the right to fair and just treatment, and that protecting and promoting equity is essential to achieving peace, harmony, and productivity within and among communities. The principle of equity is derived from the notion of equality-that all people are born equal in terms of dignity and rights.

\section{Freedom}

The sub-domain Freedom focuses on the concept that all people should have freedom of belief, freedom of speech, freedom from fear, and freedom from want, as articulated in the United Nations Universal Declaration of Human Rights (United Nations, 1948). Societies have a responsibility to actively protect the freedom of their members and to support the protection of freedom in all communities, including those that are not their own.

\section{Sense of community}

The sub-domain Sense of community is related to the sense of belonging and connectedness within societies, and focuses on collective responsibility and common vision that exists amongst the individuals and communities within a society. When a strong sense of community exists individuals actively appreciate and acknowledge the diversity of individuals and communities that comprise a society as well as demonstrate responsibility toward its development. It is acknowledged (in regard to this subdomain) that manifestations of sense of community vary between societies, that there may be tensions within societies between demands for social cohesion and the existing diversity of views and actions, and that the resolution of these tensions is an ongoing area of debate within many societies.

\section{Rule of law}

The sub-domain Rule of law is related to the principle that all citizens, institutions and entities including the State itself are subject and accountable to laws, which are publicly promulgated, independently adjudicated, equally enforced and consistent with international standards and norms protecting human rights (United Nations, 1948). It requires recognition of the supremacy of law, the concept that all citizens are equal before the law regardless of their background and personal characteristics (such as gender, race, religion), fairness in the application of law, separation of powers, participation in decision-making, legal certainty, as well as legal and procedural transparency.

\section{Key concepts}

Concern for the The concept that the ultimate goal of civic and community action is to common good promote conditions that advantage all members of the community.

Human rights A form of inalienable entitlement of all human beings that, for the purpose of the ICCS assessment framework, is framed by the contents of the United Nations Universal Declaration of Human Rights (United Nations, 1948).

Empathy Intellectually or emotionally taking the role or perspective of others.

Social justice The distribution of advantage and disadvantage within communities. 


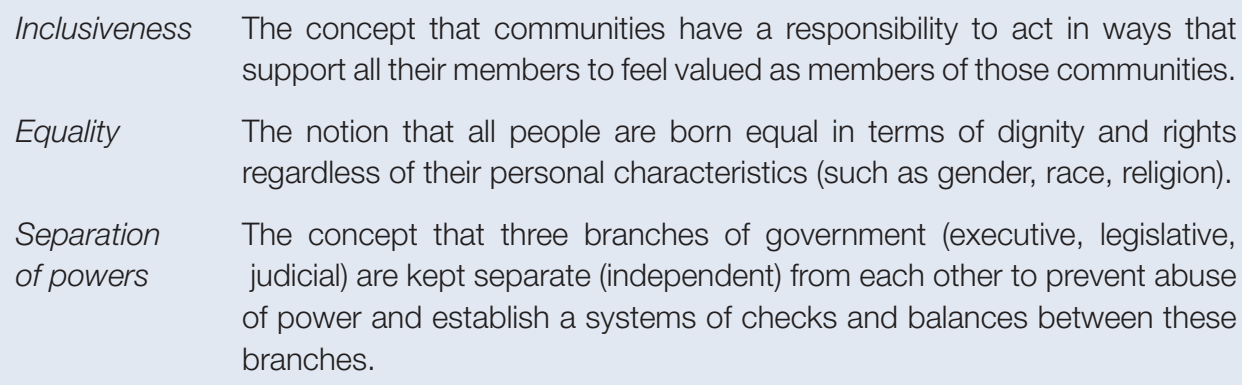

\subsubsection{Content domain 3: Civic participation}

The content domain Civic participation refers to the manifestations of individuals' actions in their communities. Civic participation can operate at any level of community and in any community context (including schools as the imminent context for the age group under study). The level of participation can range from awareness through engagement to influence. The three sub-domains of civic participation are:

- Decision-making

- Influencing

- Community participation.

\section{Decision-making}

The sub-domain Decision-making focuses on active participation that directly results in the implementation of policy or practice regarding the individual's community or a group within that community. The aspects of this sub-domain are:

- Engaging in organizational governance

- Voting.

\section{Influencing}

The sub-domain Influencing focuses on actions aimed at informing and affecting any or all of the policies, practices, and attitudes of others or groups of others in the individual's community. The aspects of this sub-domain are:

- Engaging in public debate (including participation through social media)

- Engaging in demonstrations of public support or protest (including "virtual" engagement through the use of, for example, online petitions)

- Engaging in policy development

- Developing proposals for action or advocacy

- Selective purchasing of products according to ethical beliefs about the way they were produced (ethical consumption/ethical consumerism)

- Recognizing corruption.

\section{Community participation}

The sub-domain Community participation focuses on participation, with a primary focus on enhancing a person's connections with a community, for the ultimate benefit of that community. The aspects of this sub-domain are: 
- Volunteering

- Participating in organizations

- Acquisition of information.

\section{Key concepts}

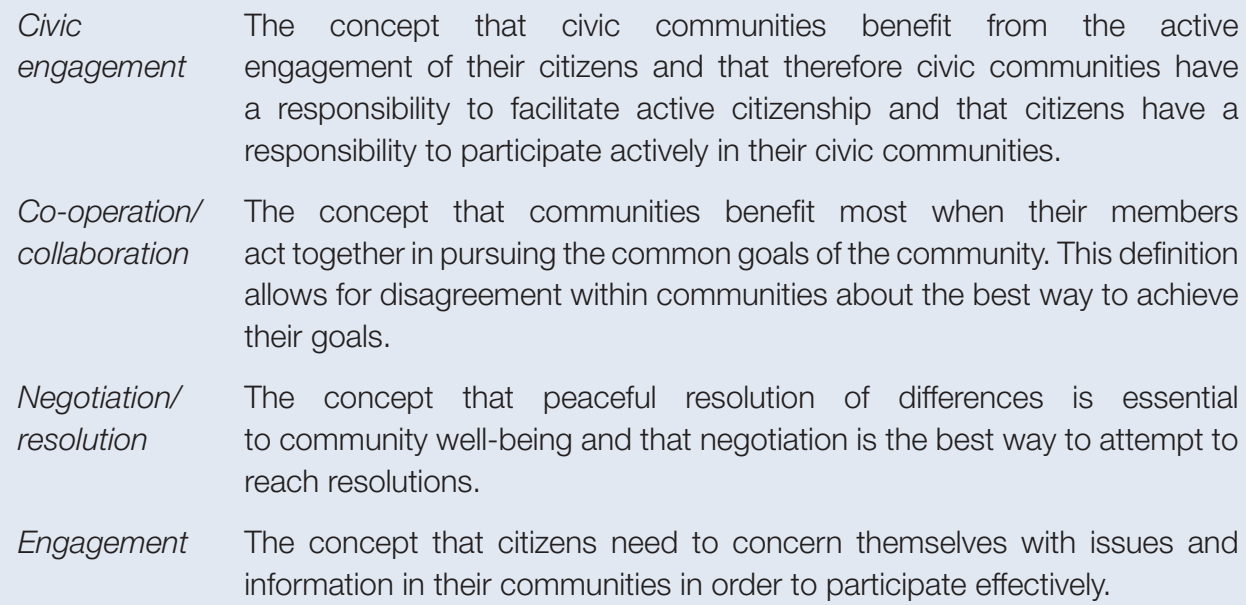

\subsubsection{Content domain 4: Civic identities}

The content domain Civic Identities includes the individual's civic roles and perceptions of these roles. As was the case with the conceptual model of CIVED, ICCS assumes that individuals both influence, and are influenced by, the relationships they have with family, peers, and civic communities. Thus, an individual's civic identity explicitly links to a range of personal and civic interrelationships. This framework asserts and assumes that individuals have multiple articulated identities rather than a single civic identity. Civic communities include points of reference at many levels ranging from family and local community to geographical regions or the global community.

Civic identities comprises two sub-domains:

- Civic self-image

- Civic connectedness.

\section{Civic self-image}

The sub-domain Civic self-image refers to the individual's experience of their place in each of their civic communities. Civic self-image focuses on the individual's civic and citizenship values and roles, the individual's understanding of and attitudes toward these values and roles, and the individual's management of these values and roles whether they are in harmony or in conflict within the individual.

\section{Civic connectedness}

The sub-domain Civic connectedness refers to the individual's sense of connection to their different civic communities and to the different civic roles the individual plays within each community. 
Civic connectedness also includes the individual's beliefs about and tolerance of the levels of diversity (of civic ideas and actions) within and across their communities, and their recognition and understanding of the effects of the range of civic and citizenship values and belief systems of their different communities on the members of those communities.

\section{Key concepts}

\begin{tabular}{|c|c|}
\hline $\begin{array}{l}\text { Civic } \\
\text { self-concept }\end{array}$ & $\begin{array}{l}\text { Individuals' view of themselves as citizens in their civic communities. } \\
\text { This view includes individuals' sense of the communities to which they } \\
\text { belong and their capacity to identify the nature and parameters of their civic } \\
\text { roles in their communities. }\end{array}$ \\
\hline Multiplicity & $\begin{array}{l}\text { Individuals' sense of the range of different roles and potentials they have } \\
\text { within and across their different communities. Included in this concept is the } \\
\text { understanding that an individual's roles and potentials are ever changing and } \\
\text { that these depend on the context of each separate community connection. }\end{array}$ \\
\hline Diversity & $\begin{array}{l}\text { Individuals' sense of and level of acceptance of the range of people and } \\
\text { viewpoints that exist within and across their communities. }\end{array}$ \\
\hline $\begin{array}{l}\text { Cultures/ } \\
\text { location }\end{array}$ & $\begin{array}{l}\text { Individuals' sense of the value and place of the cultures they associate } \\
\text { with their communities in their own civic lives and the civic lives of the other } \\
\text { members of their communities. }\end{array}$ \\
\hline Patriotism & $\begin{array}{l}\text { An individual's love for or devotion to their country (or countries), which can } \\
\text { lead to a willingness to act in support of that country (or countries). }\end{array}$ \\
\hline Nationalism & $\begin{array}{l}\text { The politicization of patriotism into principles or programs based on the } \\
\text { premise that national identity holds precedence over other social and } \\
\text { political principles. }\end{array}$ \\
\hline $\begin{array}{l}\text { Global } \\
\text { citizenship }\end{array}$ & $\begin{array}{l}\text { Individuals' sense of belonging to the global community and common } \\
\text { humanity that transcends local and national boundaries. }\end{array}$ \\
\hline $\begin{array}{l}\text { Civic and } \\
\text { citizenship } \\
\text { values }\end{array}$ & $\begin{array}{l}\text { Individuals' central ethical and moral beliefs about their civic communities } \\
\text { communities and their roles as citizens within their communities. }\end{array}$ \\
\hline
\end{tabular}

\subsection{Civic and citizenship cognitive domains}

Each of the four content domains encompasses different types of knowledge concerned with civics and citizenship (factual, procedural, conceptual and meta-cognitive) (Anderson, \& Krathwohl, 2001). The framework then considers the extent to which students develop the capacity to process the content of the four domains and reach conclusions that are broader than any single piece of knowledge. This includes the processes involved in understanding complex sets of factors influencing civic actions and planning for and evaluating strategic solutions and outcomes. It extends from direct applications of knowledge to reach conclusions about concrete situations through to the selection and assimilation of knowledge and understanding of multiple concepts in order to reach conclusions about complex, multifaceted, unfamiliar and abstract situations. This is a simplification of the hierarchy of cognitive processes articulated by Anderson and Krathwohl (2001): remembering or recalling information or processing content in terms of understanding or applying an understanding to new situations ${ }^{7}$.

7 The simplification is intended to reflect what is appropriate for students in the target grade and what is most relevant to civics and citizenship. 
Students' knowledge about civics and citizenship is measured by the ICCS cognitive test. To respond to the test items, students need to know the civic and citizenship content being assessed. Students also need to be able to apply more complex cognitive processing to their civic and citizenship knowledge and to relate their knowledge and understandings to real-world civic action.

The two ICCS cognitive domains summarize the cognitive processes that students are expected to demonstrate in the ICCS cognitive test. The data derived from the test items constructed to represent the processes in the cognitive domains will be used to construct a global scale of civic and citizenship knowledge and understandings of the four content domains. The first cognitive domain, knowing, outlines the types of civic and citizenship information that students are required to demonstrate knowledge of. The second domain, reasoning and applying, details the cognitive processes that students require to reach conclusions.

\subsubsection{Cognitive domain 1: Knowing}

Knowing refers to the learned civic and citizenship information that students use when engaging in the more complex cognitive tasks that help them make sense of their civic worlds. Students are expected to remember, recall or recognize definitions, descriptions, and the key properties of civic and citizenship concepts and content, and to illustrate these with examples. Because ICCS 2016 is an international study, the concrete and abstract concepts students are expected to know in the core cognitive assessment are those that can be generalized across societies.

\section{Processes}

$\begin{array}{ll}\text { Define } & \text { Identify statements that define civic and citizenship concepts and content. } \\ \text { Describe } & \begin{array}{l}\text { Identify statements that describe the key characteristics of civic and } \\ \text { citizenship concepts and content. }\end{array} \\ \text { Illustrate with } & \begin{array}{l}\text { Identify examples that support or clarify statements about civic and } \\ \text { examples }\end{array}\end{array}$

\subsubsection{Cognitive domain 2: Reasoning and applying}

Reasoning and applying refers to the ways in which students use civic and citizenship information to reach conclusions that are broader than the contents of any single concept and to make use of these in real-world contexts. Reasoning and applying includes, for example: the use of knowledge to reach conclusions about familiar concrete situations; the selection and assimilation of knowledge and understanding of multiple concepts; the evaluation of proposed and enacted courses of action; providing recommendations for solutions or courses of action.

\section{Processes}

Interpret Identify statements about information presented in textual, graphical, information and/or tabular form that make sense of the information in the light of a civic and citizenship concept.

Relate Use the key defining aspects of a civic and citizenship concept to explain or recognize how an example illustrates a concept. 


\begin{tabular}{ll} 
Justify & $\begin{array}{l}\text { Use evidence and civic and citizenship concepts to construct or recognize } \\
\text { a reasoned argument to support a point of view. }\end{array}$ \\
Integrate & $\begin{array}{l}\text { Identify connections between different concepts across themes and across } \\
\text { civic and citizenship content domains. }\end{array}$ \\
Generalize & $\begin{array}{l}\text { Identify civic and citizenship conceptual principles manifested as specific } \\
\text { examples and explain how these may apply in other civic and citizenship } \\
\text { contexts. }\end{array}$ \\
\hline Sugaluate & $\begin{array}{l}\text { Identify judgments about the advantages and disadvantages of alternative } \\
\text { points of view or approaches to civic and citizenship concepts and actions. }\end{array}$ \\
& $\begin{array}{l}\text { Identify courses of action or thought that can be used to alleviate } \\
\text { civic and citizenship problems expressed as conflict, tension, and/or }\end{array}$ \\
Predict & unresolved or contested ideas. \\
& Identify likely outcomes of given civic and citizenship policies strategies \\
& and/or actions.
\end{tabular}

\subsection{Civic and citizenship affective-behavioral domains}

Individuals may have developed beliefs, perceptions, dispositions, behavioral intentions and behaviors, which the ICCS 2016 framework conceptualizes as related to two affective-behavioral domains: attitudes and engagement. The ICCS student questionnaire includes items measuring the affective-behavioral domains that do not require correct or incorrect responses and are often measured through use of a Likerttype item format in the ICCS 2016 student questionnaires, indicating for example the extent to which respondents agree or disagree with a given statement. While most constructs or aspects are measured as part of the international student questionnaire, others are included as international options or in the regional student questionnaires for Europe and Latin America.

\subsubsection{Affective-behavioral domain 1: Attitudes}

The affective-behavioral domain Attitudes refers to judgments or evaluations regarding ideas, persons, objects, events, situations, and/or relationships. It is possible for individuals to harbor contradictory attitudes at the same time. Attitudes encompass responses that are focused on specifics and can change over time, as well as those reflecting broader and more fundamental (or deeply rooted) beliefs that tend to be constant over longer periods of time. ${ }^{8}$

The different types of attitude assessed in ICCS 2016 can be classified depending on their (primary) location in the four content domains:

- Students' attitudes toward civic society and systems

- Students' attitudes toward civic principles

- Students' attitudes toward civic participation

- Students' attitudes toward civic identities.

8 More enduring beliefs were conceptualized as "value beliefs" in the ICCS 2009 framework, as opposed to (less enduring and more changeable) "attitudes". However, they now form part of the same affective-behavioral domain in the ICCS 2016 assessment framework. 


\section{Students' attitudes toward civic society and systems}

The following constructs reflecting student attitudes toward civic society and systems will be measured using the international student questionnaire and the regional European and Latin American questionnaires in ICCS 2009:

- Students' perceptions of good citizenship

- Students' trust in institutions

- Students' perceptions of threats to the world's future

- Students' attitudes toward the influence of religion in society (international option)

- Students' perceptions of European future (European regional questionnaire)

- Students' attitudes toward European cooperation (European regional questionnaire)

- Students' attitudes toward the European Union (European regional questionnaire)

- Students' attitudes toward authoritarian government practices (Latin American regional questionnaire).

Students' perceptions of good citizenship: This construct refers to student beliefs regarding "good citizenship" and relates mainly to Content domain 1 (civic society and systems) but also to Content domain 2 (civic principles). Items asking about the importance of certain behaviors for "good citizenship" were included in the first IEA study on civic education in 1971 (Torney et al., 1975). In CIVED, a set of 15 items asked students to rate the importance of certain behaviors for being a good citizen (see Torney-Purta et al., 2001, p. 77f). Sub-scales concerned with conventional and with social-movementrelated citizenship were reported (see Schulz, 2004). Kennedy (2006) distinguished active (conventional and social-movement-related) from passive citizenship elements (national identity, patriotism, and loyalty). ICCS 2009 included 12 items on good citizenship behavior, most of which were similar to those used in CIVED and were used to form two scales on conventional and social-movement-related citizenship (Schulz et al., 2010b; Schulz, \& Friedman, 2011). For ICCS 2016 additional items will measure more passive forms of citizenship behavior.

Students' trust in institutions: This construct reflects students' feelings of trust in a variety of state and civic institutions in society, and relates mainly to Content domain 1 (civic society and systems). The first IEA civic education study included one item on trust in government (Torney et al., 1975). CIVED used a set of 12 items covering political/civic institutions, media, United Nations, schools, and people in general. ICCS 2009 used a similar range of 11 core items in a modified format together with three optional items on European institutions and state/provincial institutions. Across countries, results showed that students tended to express the lowest levels of trust in political parties and the highest levels of trust in courts of justice (Schulz et al., 2010b, pp. 103-109). In countries with relatively high scores on indices of corruption, and low scores on indices of government efficiency, more knowledgeable students expressed less trust in civic institutions, whereas positive correlations between civic knowledge and trust were recorded in countries with low indices of corruption (Lauglo, 2013). In ICCS 2016 student trust is measured with the same item set as in ICCS 2009, augmented by an item measuring trust in social media.

Students' perceptions of threats to the world's future: It has been reported that students express concern about global issues including those regarding poverty, hunger, wars, overpopulation and the environment (Holden 2007; Oscarsson, 1996; Rubin, 2002). 
In ICCS 2016, students are asked to rate the seriousness of a broad range of threats to key aspects of civilization such as the extent of poverty, living standards, human dignity, economic well-being, and environmental health indicating their personal level of concern. These aspects are also reflected in writings concerned with global education that envisages broadening student perspectives beyond national contexts (Burnouf, 2004; Hicks, 2003). Overall these ratings provide an indication of students' awareness of global issues and responses to individual items provide a perspective on profiles of concern.

Students' attitudes toward the influence of religion in society: Religion is often regarded as an important catalyst of civic participation (see Pancer, 2015; Putnam, \& Campbell, 2010; Verba, Schlozman, \& Brady, 1995). Smidt (1999) suggested that in the United States and Canada religious tradition and church attendance were associated with civil participation, even after controlling for the effects of other factors generally associated with civic participation. Similar findings have been reported for the United Kingdom (Storm, 2015). ICCS 2009 used a set of six items to assess students' attitudes toward religion. The set of items was part of an international option on religious denomination, practices, and attitudes toward the influence of religion in society. The results showed that in most countries students who attended religious services also held more positive attitudes towards the desirability of religious influence on society (Schulz et al., 2010b, pp. 107-113). ICCS 2016 includes a slightly modified set of questions regarding religion as an international option.

Students' perceptions of European future: Recent opinion surveys among European citizens have shown that majorities expect that their children's life will be more difficult than theirs, and that Europe's influence will be weakened in comparison with the influence of China or the United States (European Commission, 2014). The ICCS 2016 European regional questionnaire contains a new question with possible scenarios for the European future, asking students to rate the extent of their likelihood of occurring.

Students' attitudes toward European cooperation: Recent opinion polls have indicated that, in spite of a general surge in anti-European sentiment in some member countries, majorities among Europeans support decision-making about important issues at the European level (European Commission, 2014). In addition to this, results from Standard Eurobarometer survey showed that European citizens consider immigration as one of the major challenges that the EU is facing, and that it should be addressed through member states cooperation (European Commission, 2015). The European regional questionnaire in ICCS 2009 included a question measuring students' perception of harmonization in the European context, and results showed high levels of agreement with common European policies (Kerr et al., 2010). The European regional questionnaire includes a new question designed to measure students' endorsement of cooperation between European countries regarding a range of different issues.

Students' attitudes toward the European Union: Younger people have been reported to have a stronger identification with European citizenship than older age groups (European Commission, 2013). The European regional survey of ICCS 2009 showed that support for the establishment of centralized European institutions was not particularly strong, and that support for further enlargement varied considerably across participating countries (see Kerr et al., 2010). The European regional questionnaire for ICCS 2016 includes a question containing statements about the EU designed to measure students' attitudes toward this institution. 
Students' attitudes toward authoritarian government practices in Latin America: Surveys in the Latin American region have shown considerable support for authoritarian government practices among adults and adolescents, and that majorities among adult citizens supported non-democratic governments if they solved economic problems (United Nations Development Programme, 2004). Support for non-democratic government has been shown to be related to educational background, with more educated citizens being less supportive of authoritarian government practices (Cox, 2010). The Latin American regional questionnaire ICCS 2009 included items measuring the endorsement of authoritarian government practices and the justification of dictatorships (see Schulz, Ainley, Friedman, \& Lietz, 2011). Results showed that considerable proportions of lower secondary students in all participating countries showed support for non-democratic government practices, and that majorities saw dictatorships justified in case they provided economic benefits or more security. The Latin American regional questionnaire includes the same item set to measure students' attitudes toward authoritarian government practices and justification for dictatorships.

\section{Students' attitudes toward civic principles}

The following constructs reflecting student attitudes toward civic principles are measured as part of the international student questionnaire, the regional European and the Latin American regional questionnaires in ICCS 2016:

- Students' attitudes towards democratic values

- Students' attitudes toward gender rights

- Students' attitudes toward equal rights for all ethnic/racial groups

- Students' attitudes toward equal rights for immigrants (European regional questionnaires)

- Students' perception of discrimination in European societies (European regional questionnaire)

- Students'views on age limitations for young people (European regional questionnaire)

- Students' perception of discrimination of minorities in Latin American societies (Latin American regional questionnaire)

- Students' attitudes toward disobedience to the law (Latin American regional questionnaire)

- Students' sense of empathy (Latin American regional questionnaire)

- Students' attitudes toward homosexuality (Latin American regional questionnaire).

Students' perceptions of democracy: This construct refers to student beliefs about democracy and relates mainly to Content domain 2 (civic principles). In the IEA CIVED survey, students were asked to rate a number of characteristics of society as either "good or bad for democracy" (see Torney-Purta et al., 2001). ICCS 2009 used a set of nine items that measured the extent of student agreement as to what a society should be like using a set of items that were adapted from a subset of those included in CIVED. In addition, three items measured students' beliefs about what should be done in response to groups that pose threats to national security. Most of these items were endorsed by very large majorities of students across all participating countries (Schulz et al., 2010b). In ICCS 2016, students' attitudes toward democratic values are assessed using a different format that requires students to rate a number of possible characteristics of a society as "good", "bad" or "neither good nor bad" for democracy. 
Students' attitudes toward gender rights: This construct reflects student beliefs about rights for different gender groups in society. The first IEA civic education study in 1971 included four items measuring support for women's political rights. The CIVED survey used a set of six items to capture students' attitudes regarding women's political rights (Torney-Purta et al., 2001). ICCS included seven items on gender rights, some of them identical with or similar to those used in CIVED. The results showed large majorities agreeing with the positive and disagreeing with negative statements about gender equity; female students expressed more support for gender equity than males (Schulz et al., 2010b, pp. 95-98). The ICCS 2016 student questionnaire includes the same set of seven items to measure student attitudes toward gender equality.

Students' attitudes toward equal rights for all ethnic/racial groups: This construct reflects students' beliefs about equal rights for all ethnic/racial groups in a country. CIVED measured this construct with four items, while ICCS 2009 used five statements to derive a scale reflecting attitudes toward equal rights for all ethnic/racial groups (Schulz et al., 2010b; Torney-Purta et al., 2001). ICCS 2016 uses the same set of items to measure this construct.

Students' attitudes toward the rights of immigrants in European societies: This construct reflects students' beliefs about rights for immigrants. CIVED measured this construct with eight items, five of which were included in a scale reflecting attitudes toward immigrants (Schulz, 2004; Torney-Purta et al., 2001). ICCS 2009 included a slightly modified version of the same five items used for scaling, together with one additional item. In ICCS 2009, students tended to be overwhelmingly in favor of equal rights for immigrants with female students being more supportive than males (Schulz et al., 2010b, pp. 99-102). Results from the European Social Survey among adults suggest that public attitudes towards immigration are closely linked to people's educational background (Masso, 2009; Paas, \& Halapuu, 2012). Some studies show an increase in anti-immigrant attitudes among European youth (Rustenbach, 2010) and, even though no systematic data have yet been collected on this issue, further growth in refugee intake from the Middle East may have resulted in further changes. ${ }^{9}$ The regional European questionnaire in ICCS 2016 uses the same set of items to measure students' attitudes toward rights of immigrants in their country of residence.

Students' views on age limitations for young people in European societies: Legal age limits for rights to undertake different activities vary considerably across countries, even within the context of Europe. While the minimum voting age (in particular for local elections) has been lowered in some European countries, in most countries young people can only vote once they are 18 . There are also many differences across European countries with regard to the required minimum age for buying alcohol; adult surveys have shown majorities across European countries supporting 18 as the legal age limit for the acquisition of alcohol (European Commission, 2010). The European regional questionnaire includes a question asking students to choose between different legal age limits that they prefer for a number of different behaviors, including buying alcohol, voting, and driving licenses.

9 It should be noted that perceptions of refugees and immigration may differ, for example, people with positive attitudes toward immigration in general may have less favorable views about accepting refugees and vice versa. The recent growth in the numbers of refugees in many European countries is not reflected in the development of the ICCS 2016 study and the instruments do not address this distinction. 
Students' attitudes towards freedom of movement for European citizens within Europe: Freedom of movement for European citizens across EU member countries was an essential part of the Lisbon Strategy (Bongardt, \& Torres, 2012). A recent survey of adults within Europe showed that just under half of all respondents were worried about immigration from within the European Union (German Marshall Fund, 2014). EU member countries tend to have the highest share of free-movement flows in total permanent migration movements (OECD, 2012). A high degree of free movement of workers is also found in the member countries of the European Economic Area (EEA), Iceland, Liechtenstein, and Norway (Alsos, \& Eldring, 2008; Dølvik, \& Eldring, 2008). Main challenges to the principle of free movement of persons involve a disproportionate monitoring and surveillance of movement of all individuals, together with other hidden, as well as visible barriers to make movement and residence more inclusive (Carrera, 2005). The European regional questionnaire in ICCS 2009 included a set of items measuring students' perceptions regarding the freedom of movement between EU countries for European citizens, which were used to derive two constructs, one reflecting support freedom of movement, and the other preferences for restrictions. ICCS 2009 results showed student recognition of the benefits of free movement, but also large proportions in favor of restricting the movement of workers across borders (see Kerr, Sturman, Schulz, \& Burge, 2010, pp. 94-98). This principle may come into greater prominence in public discussions with the advent of large numbers of refugees and displaced people moving to and across Europe. The ICCS 2016 European regional questionnaire includes a modified set of six items measuring students' attitudes toward freedom of movement.

Students' perceptions of discrimination in European societies: Eurobarometer surveys among adults have shown that people perceive quite high levels of discrimination across European countries, in particular with regard to the ethnic origin of individuals (European Commission, 2012a). It has been suggested that people from European countries with more effective antidiscrimination laws are more knowledgeable about rights regarding discrimination (Ziller, 2014). The ICCS 2016 European regional questionnaire includes a new question presenting students with a number of statements about discrimination, for which they should rate their agreement or disagreement.

Students' perceptions of discrimination in Latin American societies: Opinion surveys among adults across Latin American countries have shown that poor people were perceived as suffering most from discrimination, followed by indigenous and afrodescendants (Chong, \& Ñopo, 2007; Nopo, Chong, \& Moro, 2010) and that perceptions of discrimination were influenced by individuals' background (skin color and ethnicity), as well as contextual factors (Canache, Hayes, Mondak, \& Seligson, 2014). The ICCS 2016 regional questionnaire for Latin America includes a set of items measuring the extent to which students perceive social groups as discriminated in their countries.

Students' attitudes toward disobedience to the law in Latin America: Cross-national adult surveys in the Latin American countries have shown a high level of ambiguity with regard to civic morality (i.e. moral behavior and acceptance of disobedience to the law), with some countries of the region recording high proportions of acceptance of law-breaking (Letki, 2006), which were particular high among young people (Torgler, \& Valev, 2004). The Latin American regional questionnaire of ICCS 2009 included a set of items measuring students' acceptance of breaking the law under different 
circumstances, and results showed that larger proportions of young people in the participating countries endorsed disobediences to the law, in particular in cases where it was perceived as the only way to achieve things, help the family, or when it was done without bad intentions. The regional questionnaire for participating Latin American countries in ICCS 2016 includes the same item set as in the previous survey, which will allow comparisons over time.

Students' sense of empathy in Latin America: A sense of empathy relates to the disposition of an individual to enter someone else's world without being influenced by their own views and values (Rogers, 1975). Distinctions are made between affective and emotional components (Eisenberg, 1995; Strayer, 1987), and cognitive processes that allow people to imagine assuming other people's roles (Piaget, 1965). A sense of emotional empathy is viewed as motivating help for others and indicating compassion and concern for other human beings (Hoffman, 1981). The Latin American regional questionnaire of ICCS 2009 included a question that asked students to rate their level of concerns when observing suffering of classmates in different situations. The results showed that females tended to express higher levels of empathy than males (Schulz, Ainley, Friedman, \& Lietz, 2011). The Latin American regional questionnaire for ICCS 2016 includes the same items as in the previous survey with on additional item designed to measure students' sense of empathy.

Students' attitudes toward homosexuality in Latin America: Survey data from the Latin American region suggest considerable differences across countries and a divided public opinion with regard to attitudes toward homosexuality in the region. For example, results from the Latinobarometer show, as a whole, people from the region did not feel homosexuality was justified and did not support same sex marriage, although considerable country differences were observed (Latinobarómetro, 2009). Attitudes towards homosexuality in the region are often influenced by age, gender, education, and religious beliefs (Kelley, 2001; Pew Research Center, 2014). In ICCS 2009, the Latin American regional questionnaire asked students to rate their agreement with a set of positive and negative statements about homosexuality, which did not form a reliable scale. In accordance with previous survey research among adults, the results showed considerable variation in attitudes across the participating countries, with majorities of students in Chile and Mexico supporting the legalization of gay marriage (Schulz, Ainley, Friedman, \& Lietz, 2011). The regional instrument for Latin America in ICCS 2016 includes a modified set of items measuring students' attitudes toward homosexuality.

\section{Students' attitudes toward civic participation}

The international and regional questionnaires for Europe and Latin American in ICCS 2016 include measures regarding the following attitudes related to civic participation:

- Students' assessment of the value of student participation at school

- Students' attitudes toward political consumerism (European regional questionnaire)

- Students' attitudes toward corrupt practices (Latin American regional questionnaire)

- Students' attitudes toward violence (Latin American regional questionnaire).

Students' assessment of the value of student participation at school: This construct reflects students' beliefs regarding the usefulness of participating in civic-related activities at school and is as such closely related to the more general concept of political efficacy. Adolescents are generally unable to vote or run for office in "adult politics," but they 
experiment as students to determine what degree of power they have to influence the ways schools are run (Bandura, 1997, p. 491). CIVED included seven items asking about students' perceptions of their influence at school. Four of these questions focused on general confidence in school participation (Torney-Purta et al., 2001). ICCS 2009 used a set of four (partly modified) CIVED items and one additional item reflecting student attitudes toward the value of student participation in civic-related activities at school. Most students across participating countries valued student participation at school, and females tended to be more supportive than male students (Schulz et al., 2010b). ICCS 2016 uses a set of five items (including four from the previous survey) to measure students' attitudes toward participation in school activities.

Students' attitudes toward political consumerism in Europe: Over the past 20 years, political or ethical consumerism has emerged as an important part of citizenship engagement; this refers to the buying or boycotting of products or services for political or ethical reasons (Micheletti, \& Stolle, 2004; Stolle, Hoghe, \& Micheletti, 2005). Political consumerism is defined as the choice of producers and products with the intention of changing institutional or market practices (Micheletti, \& Stolle, 2015). The ICCS 2016 European regional questionnaire includes a question asking students to rate their agreement or disagreement with several statements about political or ethical consumerism.

Students' attitudes toward corrupt practices in Latin America: Corruption is widely regarded as one of Latin America's most salient problems and, with few exceptions, countries in this region tend to have low indices of transparency in cross-national surveys (Transparency International, 2014). Citizens' perceptions of the level of corruption have also been found to be related to lower levels of trust in institutions (Morris, \& Klesner, 2010). Furthermore, large proportions of Latin American citizens reported in regional surveys direct experiences with corrupt practices (Morris, \& Blake, 2010) and the World Values Survey found that in this region acceptance of corruption was relatively higher than in other countries (Torgler, \& Valev, 2004). In its Latin American regional questionnaire, ICCS 2009 gathered data about young people's attitudes toward corrupt practices, and results showed an acceptance of corrupt practices by many, albeit not a majority of students (Schulz, Ainley, Friedman, \& Lietz, 2011). The ICCS 2016 Latin American regional questionnaire includes the same question as in the previous survey, and will allow changes in attitudes since 2009 to be monitored.

Students' attitudes toward violence in Latin America: Among the pressing problems that Latin American societies are facing, violence and crime are those with wide-reaching consequences for young people's socialization into society (Reimers, 2007). Exposure to violence has been identified as causing higher levels of aggressive and violent behavior among young people (Chaux, 2009; Chaux, \& Velázquez, 2009). Young people with supportive attitudes towards violence are more likely to participate in violent behavior themselves (Copeland-Linder, Johnson, Haynie, Chung, \& Cheng, 2012). The ICCS 2009 Latin American questionnaire asked students to rate their agreement or disagreement with a series of statements about the use of violence. While most students rejected positive statements about the use of violence, males tended to be more supportive of violence than females (Schulz, Ainley, Friedman, \& Lietz, 2011). In the Latin American regional questionnaire for ICCS 2016, students are presented with the question augmented by two further new items designed to measure students' attitudes toward the use of violence. 


\section{Students' attitudes toward civic identities}

The following constructs reflecting student attitudes toward civic identities were measured as part of the international student questionnaire or the European and Latin American regional questionnaires in ICCS 2009:

- Students' attitudes toward their country of residence

- Students' sense of European identity (European regional questionnaire)

- Students' perceptions of their own individual future (European regional questionnaire)

- Students' acceptance of diversity (Latin American regional questionnaire).

Students' attitudes toward their country of residence: This construct reflects students' attitudes toward abstract concepts of nation. Various forms of national attachment may be distinguished (symbolic, constructive, uncritical patriotism, or nationalism), which differ from feelings of national identity (Huddy, \& Khatib, 2007). Kennedy (2010) argued that students in Hong Kong viewed citizenship as involving legal obligations to authorities, personal obligations to support others, and patriotic obligations to support the nation state. The CIVED survey included 12 items reflecting attitudes toward the students' country. Four of these items were used to measure a construct called positive attitudes toward one's nation (Torney-Purta et al., 2001) while another set of four items reflected protective nationalism (Barber, Fennelly, \& Torney-Purta, 2013). ICCS 2009 used a set of eight items (four of them from CIVED) to measure students' attitudes toward the country they live in. The results showed that large majorities across participating countries endorsed positive statements about their countries of residence; however, notable differences were recorded between young people with and without immigrant backgrounds (Schulz et al., 2010b, pp. 101-104). ICCS 2016 assesses attitudes toward their country (of residence) using a slightly reduced set of items measuring students' attitudes toward their country of residence.

Students' sense of European identity: European identity and its citizens' sense of belonging have been important themes of debate over the past decade within the EU (Alnæs, 2013; Checkel, \& Katzenstein, 2009; European Commission, 2012b; Delanty 1995, 2006; Delanty, \& Rumford, 2005; Duchesne, 2008; Herrmann, Risse, \& Brewer, 2004; Karolewski, \& Kaina, 2006, 2013; Pichler, 2008; Spannring, Wallace, \& Datler, 2008). The establishment of European institutions and integration of EU member countries, and in particular the signing of the Treaty on the European Union (better known as the Treaty of Maastricht), have had consequences for the concept of European identity and citizenship (Osler, \& Starkey, 2008). While some scholars claim that supra-national identities have superseded national identities (see for example, Osler, \& Starkey, 2001, 2008; Soysal, 1994), others hold that notions of national citizenship still remain dominant (Delanty, 2007; Fligstein, 2009). The European regional questionnaire of ICCS 2009 included a question about the extent to which lower-secondary students have developed a sense of European identity. Results showed that, while most students regarded themselves as Europeans, relatively few students viewed their European identity as more important than their national identity (Kerr et al., 2010). The European regional questionnaire for ICCS 2016 includes the same question as in the previous survey in order to measure changes in the sense of European identity over time. 
Students' perceptions of their own individual future in European societies: In a previous part of the framework, we drew attention to the need to examine perceptions of the future held by students. There is a body of literature concerned with the measurement of beliefs about, and perceptions of the future or future time perspectives (Husman, \& Shell, 2008). This measurement goes beyond simple measures of dispositional optimism and pessimism (Lemola, Raikkonen, Mathews, Schier, Heinonen, Pesonen, \& Lahti, 2010). Examining perceptions of the future involve an element of appraisal, as well as a response to that appraisal. We have already noted the evidence that adults in European countries think that life for the next generation will be more difficult that it was for themselves (European Commission, 2014). The ICCS 2016 European regional questionnaire asks students about the likelihood of finding employment and better financial conditions in the future.

Students' acceptance of diversity in Latin America: Acceptance of minority groups and the rejection of discrimination can be viewed as essential for ensuring the well-being for all members of society, as well as an educational goal (Cabrera, Nora, Terenzini, Pascarella, \& Hagedorn, 1999; Cote, \& Erikson, 2009; Morley, 2003). An example of the integration of this educational aim for civic and citizenship education is the Colombian program Citizenship Competencies, which encompasses learning about pluralism, identity, and respect for diversity, as well as issues related to exclusion and discrimination (Chaux, Lleras, \& Velázquez, 2004; Ministry of Education of Colombia, 2004). The ICCS 2009 Latin American questionnaire included a set of items measuring the acceptance of different social minority groups as neighbors. While most students across the six participating countries were tolerant of people with different nationality, from other regions of the country, or with a different skin color, fewer students approved of people with a different sexual orientation in their neighborhood (Schulz, Ainley, Friedman, \& Lietz, 2011). Acceptance of social minority groups tended be positively associated with civic knowledge, and had negative correlations with authoritarian attitudes (Caro, \& Schulz, 2012). The Latin American regional questionnaire for ICCS 2016 includes a modified set of items measuring students' acceptance of social minorities in their neighborhood.

\subsubsection{Affective-behavioral domain 2: Engagement}

The affective-behavioral domain Engagement refers to students' civic engagement, students' expectations of future action, and their dispositions to actively engage in society (interest, sense of efficacy). This affective-behavioral domain, assessed in the student perceptions questionnaire, requires items that ask students about their intentions toward civic action in the near future or when they are adults, as well as items measuring the extent to which students are interested and feel competent to engage. Given the age group to be surveyed in ICCS 2016 and the limitations that adolescents face in participating as active citizens, students' dispositions towards engagement are of particular importance when collecting data about active citizenship. In addition to active involvement in those civic forms open to this age group (such as school-based activities, youth organizations, or community groups), young people may now become involved in virtual networks through new social media. These relatively new forms of engagement are considered more explicitly in ICCS 2016. 
While indicators of engagement are mainly related to the content domain civic participation, they are also concerned with other content domains (mainly at the level of individual items). For example, a student's expected membership in a political party is related to the content domain civic society and systems, a student's expected engagement in political consumerism to the content domain civic principles, and a students' participation in a group to help the local community to civic identity.

One important aspect of measuring dispositions toward civic engagement in the area of civics and citizenship, which has traditionally been a central focus in political science research, is political participation. It can be defined as "activity that has the intent or effect of influencing government action-either directly by affecting the making of implementation of public policy or indirectly by influencing the selection of people who make those policies" (Verba et al., 1995, p. 38). Putnam (1993, p. 665) regarded civic engagement more broadly as "people's connections with the life of their communities, not merely politics."

Verba et al. (1995) identified the following three factors as predictors of political participation: (i) Resources enabling individuals to participate (time, knowledge); (ii) psychological engagement (interest, efficacy); and (iii) "recruitment networks," which help to bring individuals into politics (these networks include social movements, church, groups, and political parties). Inequality in citizens' opportunities for political participation has been raised as an issue for democracy, in particular in the United States (see for example Schlozman, Verba, \& Brady, 2012). There is a general consensus regarding the importance of formal education in influencing the extent of adult engagement in society (see Nie, Junn, \& Stehlik-Barry, 1996; Pancer, 2015).

During the 1970s and 1980s, protest behavior as a form of participation became more prominent in Western democracies (Barnes, \& Kaase, 1979). Scholars have distinguished "conventional" (voting, running for office) from "unconventional (social movement)" activities (grass-root campaigns, protest activities). They have also distinguished among the latter legal from illegal forms of behavior (Kaase, 1990). In view of the rapid expansion of new types of political activities, Van Deth (2014) proposed a classification of political participation, which, in addition to conventional and unconventional types of engagement, also included problem- or community-oriented forms of participation and individualized and creative modes of participation.

According to Ekman and Amnå (2012), it is necessary to distinguish civic participation (latent political participation) from manifest political participation, as well as individual forms from collective forms of engagement. Ekman and Amnå distinguished forms of latent involvement (such as interest and attentiveness) from more active forms of engagement (defined as either individual or collective activities). With regard to political passivity, which has been observed as a growing phenomenon especially among young people, it is important to distinguish unengaged from disillusioned citizens (Amnå, \& Ekman, 2014). While unengaged passive citizens are still keeping themselves informed and are willing to consider civic engagement if needed, disillusioned passive citizens have lost faith in the possibility of influencing and have become alienated. Therefore, in addition to active engagement, basic dispositions toward engagement (interest or self-efficacy) and behavioral intentions (underlying preparedness to take action) are of crucial importance when studying young people's engagement. 
In recognition of the above, and also in view of the fact that young people at age of 1315 years are limited with respect to the extent in which they can participate in society, indicators of engagement are conceptualized according to the following typology:

- Dispositions

- Behavioral intentions

- Civic participation.

\section{Dispositions}

With regard to students' dispositions toward civic engagement, ICCS 2016 will distinguish the following dispositions toward engagement:

- Students' interest in political and social issues

- Students' sense of citizenship self-efficacy.

Students' interest in political and social issues: The first IEA Civic Education Study in 1971 included measures of interest in public affairs television, which turned out to be a positive predictor of civic knowledge and participation (Torney et al., 1975). An item on political interest was used in the CIVED survey (Torney-Purta et al., 2001). Similar to earlier findings, CIVED results also showed interest in politics as a positive predictor of civic knowledge and likelihood to vote (Amadeo et al., 2002). ICCS 2009 used a list of items covering students' interest in a broader range of six different political and social issues, including an optional item referring to interest in European politics. The results showed that students tended to have considerable interest in social and also political issues in their own countries, but were less interested in international politics (Schulz et al., 2010b). ICCS 2016 will assess students' interest using an additional item about their interest in political and social issues, in conjunction with a question about their parents' interest in these issues.

Students' sense of citizenship self-efficacy: This construct reflects students' self-confidence in active citizenship behavior. Individuals' "judgments of their capabilities to organize and execute courses of action required to attain designated types of performances" (Bandura, 1986, p. 391) are deemed to have a strong influence on individual choices, efforts, perseverance, and emotions related to the tasks. The concept of self-efficacy constitutes an important element of Bandura's social cognitive theory about the learning process, in which learners direct their own learning (Bandura, 1993). The distinction between self-concept regarding political participation (political internal efficacy) and citizenship self-efficacy is that: whereas internal political efficacy asks about global statements regarding students' general capacity to act politically, citizenship selfefficacy asks about the students' self-confidence to undertake specific tasks in the area of civic participation. ICCS 2009 included seven items reflecting different activities that were relevant for students of this age group, which are also included in the ICCS 2016 student questionnaire.

\section{Behavioral intentions}

ICCS 2016 will distinguish between the following three types of behavioral intentions:

- Expectations to participate in legal and illegal forms of civic action in support of or protest against important issues

- Expectations of political participation as adults

- Expectations of participating in future school-based activities. 
Students' expectations to participate in forms of civic action: In ICCS 2009 a set of nine items reflected students' expectations for future involvement in protest activities (for example, collecting petitions, participating in protest marches, blocking traffic). The items related to two different dimensions of protest behavior: legal and illegal. In ICCS 2016 items measure forms of civic action, including those in protest against and in support of particular issues, using a similar set of items. The items include actions in support of environmental sustainability, as well as use of new social media.

Students' expectations of political participation as adults: Young people who intend to participate in political activities have been shown to be much more likely to actually participate at a later point in time (Eckstein, Noack, \& Gniewosz, 2013). In ICCS 2009 these types of behavioral intentions were measured with set of nine items (two of which were optional for countries), which was used to measure two different constructs (expected electoral participation and expected participation in political activities). While majorities of students across participating countries expected to participate in elections, relatively few students expressed intentions to engage in more active forms of political participation (Schulz et al., 2010b, pp. 143-146). The ICCS 2016 student questionnaire includes the same set of ICCS 2009 items, augmented by a number of items measuring more informal ways of citizen participation in society (including one new item regarding personal efforts to help the environment).

Students' expectations of participating in future school-based activities: The theory of planned behavior links attitudes to behaviors through intentions (Ajzen, 2001; Ajzen, \& Fishbein, 2000). This theory posits that attitudes influence actions through reasoned processes (that are manifested as intentions). For example, intentions formed relatively early in secondary school are powerful predictors of subsequent participation in education (Khoo, \& Ainley, 2005). More specifically related to citizenship, Keating and Janmaat (2015) reported analyses of longitudinal data in the United Kingdom, and suggested that participation in school-based political activities has a positive influence on future electoral and political engagement. A set of items measuring this construct were developed for ICCS 2016 to reflect students' beliefs about their expectation of undertaking future civic activities within the school context (for example, voting in school elections or engaging in a public debate about school-related issues).

\section{Civic participation}

Students at the age group under study in ICCS are not yet old enough to have access to many forms of citizenship participation in society. However, there is evidence of links between youth participation and later engagement as adult citizens (see for example, Verba et al., 1995). Furthermore, having been part of civic-related activities at school has been suggested as factor influencing future citizenship engagement (Pancer 2015; Putnam, 2000). In view of the latter, it needs to be acknowledged that current or past involvement in youth groups, school governance or campaigns may play a role as contextual factor in determining civic-related learning outcomes.

ICCS 2016 includes measures of the following types of more active students' civic engagement:

- Students' engagement with social media

- Students' engagement in organizations and groups (outside of school)

- Students' engagement in school activities. 
Students' civic participation through social media: The importance of social media has risen exponentially over the past years (Banaji, \& Buckingham, 2013; Mihailidis, 2011; Rainie, Smith, Schlozman, Brady, \& Verba, 2012; Segerberg, \& Bennett, 2011) and research suggests a potential enhancement of civic participation among people when content is interactive (for example, via chat rooms or message boards) instead of the one-way communication of more traditional media (Bachen et al., 2008; Kahne et al., 2011). The ICCS 2016 student questionnaire includes three new items that measure the extent to which students engage with political and social issues via social media.

Students' civic participation in the organizations and groups: Citizens' involvement in organizations and groups can be seen as a clear indicator of civic engagement (Putnam, 2000; Van Deth, Maraffi, Newton, \& Whiteley, 1999). However, it can also be regarded as a resource for future engagement (Putnam, 1993). The ICCS 2009 student questionnaire asked students about their current or past participation in organizations in their communities, such as human-rights groups, religious associations, and/or youth clubs. Similar to the findings of the CIVED study in 1999 (Amadeo et al., 2002; Torney-Purta et al., 2001), ICCS 2009 results showed that only minorities among students reported to have participated in these organizations or groups (Schulz et al., 2010b, pp. 129-134). ICCS 2016 assesses students' participation in the community with a slightly modified set of 10 items (including three optional items).

Students' civic participation in school activities: Numerous scholars have underlined the importance of students' experience at school for developing a sense of having power to influence matters in the community (Bandura, 1997). Research has provided evidence that more democratic forms of school governance can contribute to higher levels of political engagement (see for example Mosher, Kenny, \& Garrod, 1994; Pasek, Feldman, Romer, \& Jamieson, 2008). The ICCS 2009 student questionnaire asked students about a wide range of civic-related participation at school (for example, in school councils/ parliaments, or in student debates). The results showed that majorities of students reported to have participated in many of these activities in school, and that there were positive associations with civic knowledge and engagement (Schulz et al., 2010b). ICCS 2016 assesses students' participation at school with a slightly modified set of eight items (including one optional item).

\subsection{Mapping items to domains}

The content domains relate to both cognitive and affective-behavioral domains. Any item that measures one of the two cognitive domains can be mapped to any of the four content domains. The same is true for items measuring any of the affective-behavioral constructs. Table 2.1 shows how items can be placed in different cells and mapped to either cognitive or affective-behavioral domains, as well as to content domains.

Cognitive items from both domains (knowing and reasoning and applying) and affectivebehavioral items from two domains (attitudes and engagement) were developed in the contexts of all four content domains. Because these mappings are guided by the compatibility of each content domain to the different affective-behavioral and cognitive domains, they do not necessarily spread evenly across the content domains. 
Table 2.1: Relationship between cognitive or affective-behavioral and content domains

\begin{tabular}{|c|c|c|c|c|}
\hline & $\begin{array}{c}\text { Content } \\
\text { domain 1: } \\
\text { Civic society } \\
\text { and systems }\end{array}$ & $\begin{array}{c}\text { Content } \\
\text { domain 2: } \\
\text { Civic principles }\end{array}$ & $\begin{array}{c}\text { Content } \\
\text { domain 3: } \\
\text { Civic participation }\end{array}$ & $\begin{array}{c}\text { Content } \\
\text { domain 4: } \\
\text { Civic identities }\end{array}$ \\
\hline \multicolumn{5}{|l|}{$\begin{array}{l}\text { Cognitive } \\
\text { domains }\end{array}$} \\
\hline Knowing & 1 & $\|$ & III & IV \\
\hline $\begin{array}{l}\text { Reasoning and } \\
\text { applying }\end{array}$ & V & $\mathrm{VI}$ & VII & VIII \\
\hline \multicolumn{5}{|l|}{$\begin{array}{l}\text { Affective- } \\
\text { behavioral } \\
\text { domains }\end{array}$} \\
\hline Attitudes & $A$ & B & C & $D$ \\
\hline Engagement & $E$ & $\mathrm{~F}$ & $G$ & $\mathrm{H}$ \\
\hline
\end{tabular}

The following examples illustrate the mapping of items to domains (see Chapter 4 for information on the coverage of framework domains in the ICCS 2016 main survey instruments):

- A cognitive item that measures student knowledge about the role of parliament would be located in cell I (Cognitive domain: Knowing; Content domain 1: Civic society and systems).

- A cognitive item measuring student ability to identify the underlying reason for a civic protest would be found in cell VII (Cognitive domain: Reasoning and applying; Content domain 3: Civic participation).

- An affective-behavioral item asking about students' valuing of their country's flag would be located in cell D (attitude related to Content domain 4: Civic identities).

- An affective-behavioral item asking about students' trust in parliament would be located in cell A (attitude related to Content domain 1: Civic society and systems).

- An affective-behavioral item asking about students' expectations to vote in national elections would be located in cell G (engagement item related to Content domain 3: Civic participation).

- An affective-behavioral item asking about students' interest in political and social issues would be located in cell $\mathrm{E}$ (engagement item related to Content domain 1: Civic society and systems).

Open Access This chapter is distributed under the terms of the Creative Commons AttributionNonCommercial 4.0 International License (http://creativecommons.org/licenses/by-nc/4.0/), which permits any noncommercial use, duplication, adaptation, distribution and reproduction in any medium or format, as long as you give appropriate credit to the original author(s) and the source, provide a link to the Creative Commons license and indicate if changes were made.

The images or other third party material in this chapter are included in the works Creative Commons license, unless indicated otherwise in the credit line; if such material is not included in the works Creative Commons license and the respective action is not permitted by statutory regulation, users will need to obtain permission from the license holder to duplicate, adapt or reproduce the material. 


\section{Contextual Framework}

\subsection{Contexts for civic and citizenship education}

A study of civic-related learning outcomes and civic engagement needs to take the context in which civic and citizenship education occurs into account. Young people develop their understandings about their roles as citizens in contemporary societies through activities and experiences that take place within homes, schools, classrooms, and the wider community. It is therefore important to recognize that young people's cognitive and affective-behavioral learning outcomes are potentially influenced by variables that can be located at different levels in a multi-level structure (see Travers, Garden, \& Rosier, 1989; Travers, \& Westbury, 1989; Scheerens, 1990; Scheerens, \& Bosker, 1997).

The individual student is located within overlapping contexts of school and home. Both contexts form part of the local community that, in turn, is embedded in the wider sub-national, national, and international contexts. The contextual framework for ICCS distinguishes the following levels:

- Context of the wider community: This level comprises the wider context within which schools and home environments work. Factors can be found at local, regional, and national levels. For some countries, the supra-national level might also be relevant as, for example, in member countries of the European Union. Given the increased importance of new social media, virtual communities connected through the internet also form part of this context.

- Context of schools and classrooms: This level comprises factors related to the instruction students receive, the school culture, and the general school environment. ${ }^{10}$

- Context of home and peer environments: This level comprises factors related to the home background and the immediate social out-of-school environment of the student (for example, peer-group activities).

- Context of the individual: This level refers to the individual characteristics of the student.

Another important distinction can be made by grouping contextual variables into antecedents or processes:

- Antecedents are those variables that shape how student learning and acquisition of civic-related understandings and perceptions takes place. Note that these factors are level-specific and may be influenced by antecedents or processes at a higher level. For example, civic-related training of teachers may be affected by historical factors and/ or policies implemented at the national level.

- Processes are those variables related to civic-related learning and the acquisition of understandings, competencies, and dispositions. They are constrained by antecedents and possibly influenced by variables relating to the higher levels of the multi-level structure.

10 Because of the sampling design for ICCS, school level and classroom level cannot be disentangled. Generally, only one classroom will be selected within each sampled school. 
Antecedents and processes are variables that have potential impact on the outcomes at the level of the individual student. Learning outcomes related to civic and citizenship education at the student level also can be viewed as aggregates at higher levels (school, country) where they can affect factors related to process. For example, higher levels of civic understanding and engagement among students may influence the way schools teach civic and citizenship education.

Figure 3.1 illustrates contextual variables which might influence the learning outcomes of civic and citizenship education. There is a reciprocal relationship between processes and outcomes, which emphasizes that "feedback" may occur between civic-related learning outcomes and processes. For example, students with higher levels of civic knowledge and engagement are those students most likely to participate in activities (at school, at home, and within the community) that promote these outcomes.

There is a unidirectional relationship between antecedents and processes at each level. However, higher-level processes may influence antecedents, and it is likely that, from a long-term perspective, outcomes may affect variables that are antecedents for learning processes.

Figure 3.1: Contexts for the development of learning outcomes related to civic and citizenship education

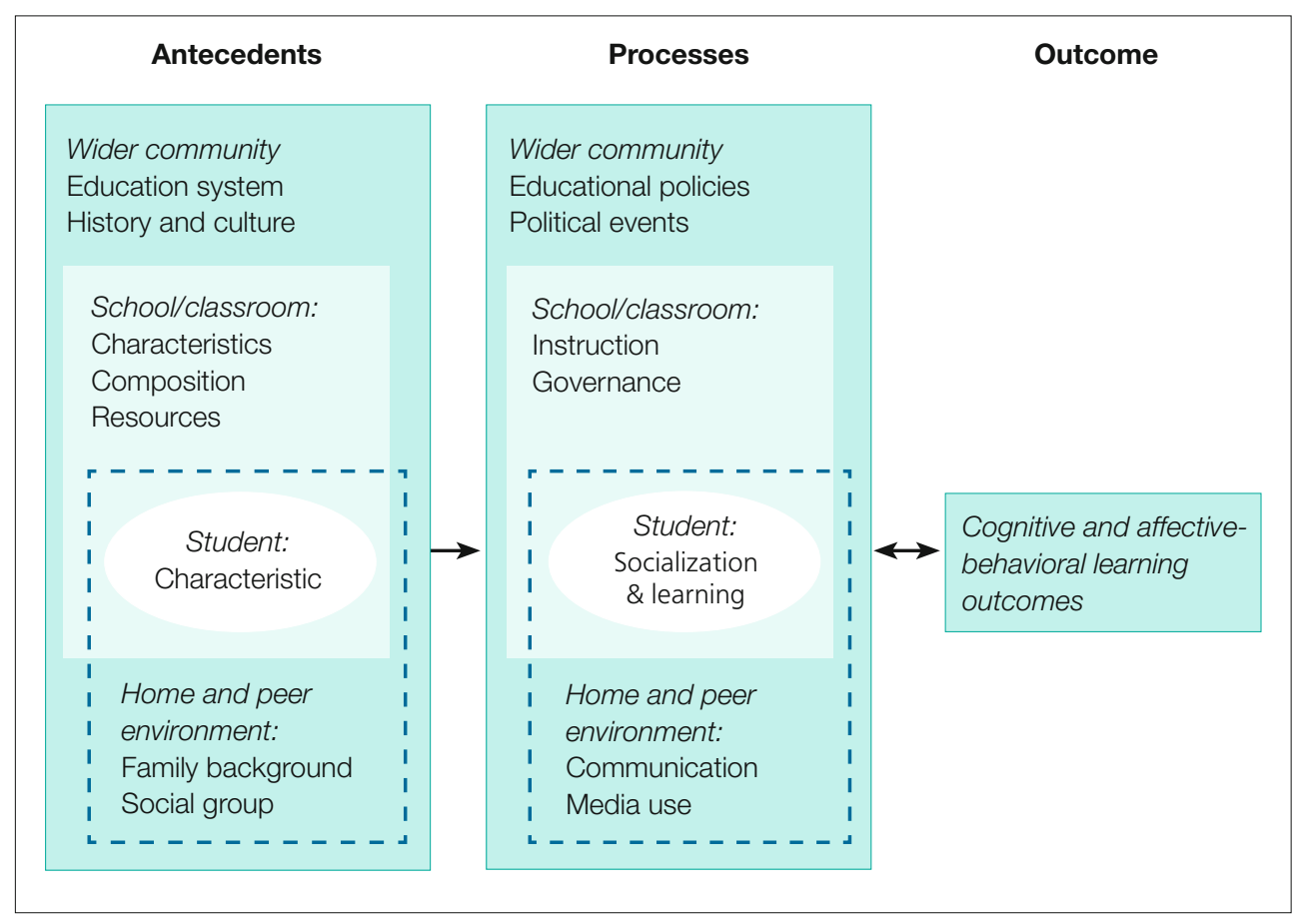


This contextual framework for ICCS makes it possible to map variables for which data are collected on a three-by-four grid, with antecedents, processes, and outcomes as columns, and the levels of country/community, school/classroom, student, and home environment as rows (Table 3.1). Although the last column for outcomes is not split into levels, it is important to recognize that, for the analysis, aggregates can also be used at wider community or school/classroom levels. ${ }^{11}$

Table 3.1 shows examples of potential variables (or groups of variables) collected with different ICCS instruments for each cell in this grid. Variables related to the context of country/community are collected primarily through the national contexts survey and other possible data sources. Variables related to the context of schools and classrooms are collected through the school and teacher questionnaires. The student background questionnaire provides information on antecedents of the individual student and the home environment as well as about some process-related variables (for example, learning activities). The student test and the student perceptions questionnaire will collect data on outcomes. In addition, the student background questionnaire will include questions regarding student participation in civic-related activities, which will also be used as indicators of active citizenship related to Content domain 3 (civic practices).

Some potential variables that can be measured at one level pertaining to another level are not included in the mapping shown in Table 3.1. Student observations of learning practices in the classroom can be aggregated and used as classroom or school variables. Student, school, and teacher questionnaires might also provide civic-related information about the context of the local community.

Table 3.1: Mapping of variables to contextual framework (examples)

\begin{tabular}{|c|c|c|c|}
\hline Level of ... & Antecedents & Processes & Outcomes \\
\hline $\begin{array}{l}\text { Wider } \\
\text { community }\end{array}$ & $\begin{array}{l}\text { NCS \& other sources: } \\
\text { Democratic history } \\
\text { Structure of education }\end{array}$ & $\begin{array}{l}\text { NCS \& other sources: } \\
\text { Intended curriculum } \\
\text { Political developments }\end{array}$ & \multirow{4}{*}{$\begin{array}{l}\text { StT \& StQ/RQ: } \\
\text { Test results } \\
\text { Student attitudes } \\
\text { and engagement }\end{array}$} \\
\hline School/classroom & $\begin{array}{l}\text { ScQ \& TQ: } \\
\text { School characteristics } \\
\text { Resources }\end{array}$ & $\begin{array}{l}\text { ScQ \& TQ: } \\
\text { Implemented } \\
\text { curriculum } \\
\text { Policies and practices }\end{array}$ & \\
\hline Student & $\begin{array}{l}\text { StQ: } \\
\text { Gender } \\
\text { Age }\end{array}$ & $\begin{array}{l}\text { StQ: } \\
\text { Civic learning } \\
\text { Practiced engagement }\end{array}$ & \\
\hline $\begin{array}{l}\text { Home and peer } \\
\text { environment }\end{array}$ & $\begin{array}{l}\text { StQ: } \\
\text { Parent SES } \\
\text { Ethnicity } \\
\text { Language } \\
\text { Country of birth }\end{array}$ & $\begin{array}{l}\text { StQ: } \\
\text { Family communication } \\
\text { Communication } \\
\text { with peers } \\
\text { Media information }\end{array}$ & \\
\hline
\end{tabular}

Note: $\mathrm{NCS}=$ national contexts survey; $\mathrm{SCQ}=$ school questionnaire; $\mathrm{TQ}=$ teacher questionnaire; $\mathrm{RQ}=$ regional questionnaire; StQ = student questionnaire; StT = student test; SES = socioeconomic status.

11 Note that similar conceptualizations have been used for the planning of other international studies (see, for example, Harvey-Beavis, 2002; OECD, 2005; Travers, \&Westbury, 1989; Travers et al., 1989). 


\subsection{The context of the wider community}

The context of the wider community can be viewed as consisting of different levels: the local community in which students' schools, as well as home and peer environments, are embedded within broader contexts of regional, national, and possibly supranational contexts. Within the scope of ICCS, the level of the community and the level of the national context are the most relevant levels.

\subsubsection{The context of the educational system}

To study the ways students develop civic-related dispositions and competencies and acquire understandings with regard to their role as citizens, it is important to take variables found at the country level into account. Historical background, the political system, the structure of education, and the curriculum provide important contextual information when interpreting results from an international assessment of civic and citizenship education. Data from official statistics will provide a range context data at the level of countries regarding the structure of the education system, the nature of the political system, and the economic and social context of the society. However, comparable data from published sources will not always be available to provide a picture of the context for civic and citizenship education in all participating countries.

The national contexts survey for ICCS 2016 is designed to collect systematically relevant data that are not always available from existing sources. These data include information on the structure of national education systems, education policies and approaches to civic and citizenship education, teacher training in general and for civic and citizenship education in particular, and approaches to assessment and quality assurance regarding the area of civic and citizenship education. The survey also collects information on current debates and reforms regarding this learning area.

Data from published sources and from the national contexts survey will be used to compare profiles of civic and citizenship education in participating countries. In addition, national context data will be used for the analysis of differences among countries in student knowledge and engagement related to civic and citizenship education.

The structure of the education system: Despite a number of global trends in education that have led to similarities in policies and structures (Benavot, Cha, Kamens, Meyer, \& Wong, 1991), the differences between education systems continue to have a considerable effect on the outcomes of education (Baker, \& LeTendre, 2005). To capture these basic differences, ICCS 2016 collects data on the structure of school education (study programs, public/private school management, types of primary and secondary education institutions), the autonomy of educational providers, and the length of compulsory schooling.

Education policies regarding civic and citizenship education: Results from ICCS 2009 (Ainley et al., 2013) showed that the status of and priority given to civic and citizenship education were mostly regarded as low across participating countries. Generally, civic goals were deemed as important, however, there were varying approaches regarding the delivery of curricular content across countries, either through its integration into different subjects, teaching as part of a distinct subject, and/or definition as a crosscurricular learning area. ICCS 2009 findings also highlighted the fact that explicit civic and citizenship education often starts after students reached the age of 14 . 
The last decade has witnessed numerous examples of educational reforms in many countries, with the overall aim of improving educational provision and outcomes, including those concerning civic and citizenship education. Many of these educational reforms were implemented in response to the challenges of learning and living in modern societies, as well as changes in political systems (Ainley et al., 2013; Cox, Jaramillo, \& Reimers, 2005).

The ICCS 2016 national contexts survey collects data on the definition of, and the priority given to, civic and citizenship education in the educational policy and its provision in each participating country at the time of the data collection. National centers will provide information about official definition of civic and citizenship education, its place in the curriculum in primary and secondary education, and its main goals. National centers are also asked about the potential influence of historical, cultural, political, and other contexts on the character of and approach to civic and citizenship education, and whether there have been any changes since the previous survey in 2009.

Civic and citizenship education and school curriculum approaches: Countries take different approaches to the implementation of civic and citizenship education in their curricula and the ways civic and citizenship education is generally implemented vary considerably across countries (Ainley et al., 2013; Cox et al., 2005; Eurydice, 2005). Some educational systems have it in the national curriculum as a compulsory or optional (stand-alone) subject, whereas others include it through integration into other subjects. An alternative approach to civic and citizenship education is to implement it as a crosscurricular theme or through the so called "whole school approach". ICCS 2009 results showed that in many education systems and/or schools more than one approach is implemented at the same time (Ainley et al., 2013).

With regard to school curriculum approaches for civic and citizenship education, Eurydice (2012) distinguished (i) promotion through steering documents such a national curricula or other recommendations/regulations, (ii) support for school-based programs and projects, and (iii) the establishment of political structures (such as school parliaments). In this context it is also important to review the extent to which schools in different countries provide support for civic and citizenship education through school culture or ethos, democratic school governance, and the establishment of links with the wider community (Birzea et al., 2004; Eurydice, 2012). Results from ICCS 2009 showed that many countries include recommendations with regard to the establishment of democratic school practices in their educational policies (see Ainley et al., 2013).

The national contexts survey in ICCS 2016 gathers data on the inclusion of civic and citizenship education (as a separate subject, or integrated into different subjects, or as cross-curricular approach) in the formal curriculum at different stages of schooling and in different study programs. The survey also captures the names of specific curriculum subjects and whether they are compulsory or optional in each study program. Furthermore, the national contexts survey gathers data on goals of the national or official curricula for civic and citizenship education regarding the inclusion of specific contexts with regard to whole school approaches, school curriculum approaches, student participation or parental involvement, and links to the wider community. 
Because ICCS 2016 surveys students at a specific target grade in lower secondary programs (typically Grade 8), it will be important to gather information about the curricular context for civic and citizenship education in this particular grade. Furthermore, national centers are asked to report on the specification of topics, objectives and processes when implementing the school curriculum, as well as specifications regarding the amount of instructional time given to civic and citizenship education.

Teachers and civic and citizenship education: The teacher survey undertaken as part of the CIVED survey showed a great deal of diversity in the subject-matter background, professional development, and work experience of those teachers involved in civic and citizenship education (Losito, \& Mintrop, 2001). With regard to teacher training in this field, research showed a rather limited and inconsistent approach to in-service training and professional development (Birzea et al., 2004; Eurydice, 2005, 2012). The results of the ICCS 2009 national contexts survey showed that, in most participating countries, pre-service and in-service training was provided but, in most cases, this provision was reported as non-mandatory (Schulz et al., 2010b, pp. 53-56).

To assess the variety of different approaches to teacher education in the field at the level of education systems, the national contexts survey in ICCS 2016 collects general data about the requirements for becoming a teacher and about licensing or certification procedures for teachers. More specifically, the survey also gathers data about the characteristics of teachers of civic and citizenship education and the extent to which civic and citizenship education is part of pre-service or initial teacher education, and on the availability of in-service or continuing professional development education in general, and for civic and citizenship education in particular, from the providers of these activities.

Assessment and quality assurance in civic and citizenship education: Comparisons of assessment and quality assurance for civic and citizenship education are difficult and complex due to the diversity of approaches to teaching this subject area across countries. In particular, research in Europe shows that, in most countries, and compared to other subject areas, monitoring and quality assurance in civic and citizenship education are often unconnected and carried out on a small scale (Birzea et al., 2004). However, over the last decade, some countries have started to implement nationwide assessments of civic and citizenship education (Ainley et al., 2013; Eurydice, 2012).

The national contexts survey includes questions about the extent of assessment in the area of civic and citizenship education at the country's target grade, and how parents are informed about current approaches to this field of learning.

\subsubsection{The context of the local community and school-community relationships}

Schools and homes of students are located in communities that vary in their economic, cultural, and social resources, and in their organizational features. Inclusive communities that value community relations and facilitate active citizen engagement, especially if they are well resourced, may offer civic and citizenship opportunities for partnerships and involvement to schools and individuals. Social and cultural stimuli arising from the local community, as well as the availability of cultural and social resources, may influence young people's civic and citizenship knowledge, dispositions, and competencies in relation to their roles as citizens (Jennings, Stoker, \& Bowers, 2001). Data on the contexts and characteristics of the local community will be gathered primarily through the school questionnaire. 
Urbanization: There is evidence that students from non-urban school contexts often perform at lower achievement levels than those from urban schools (see, for example, Istrate, Noveanu, \& Smith, 2006; Webster, \& Fisher, 2000; Williams, 2005). Data on school location (urbanization) were used in multi-level analyses carried out in ICCS 2009. In most countries, a rural school location had no significant effect on students' civic knowledge, after controlling for other variables (see Schulz et al., 2010b, pp. 230232). Urbanization was associated with student knowledge in only a few countries. In Latin American countries, there were significant differences in civic knowledge between rural and urban schools that were largely associated with the socioeconomic background of individual students and their schools (Schulz, Ainley, Friedman, \& Lietz, 2011, p. 78). As in ICCS 2009, the ICCS 2016 school questionnaire includes a question about the size of the community in which the school was located.

Availability of resources in the local community: Differences in the quantity and quality of resources for citizenship learning available in the local area may have a dual effect. On the one hand, they may favor the organization of community-oriented projects and student participation in projects requiring the development of activities involving the community, both of which can contribute to developing skills and competencies related to civic and citizenship education. On the other hand, community participation in the life of the school and in its various levels can be a factor for greater openness and democratization of the school itself. Furthermore, the level of resources may influence the possibilities for the provision of local support to schools, which may have an impact on school improvement (Reezigt, \& Creemers, 2005). In ICCS 2009, differences regarding the availability of resources in the local community were associated with students' civic knowledge in several countries (see Schulz et al., 2010b). They also provided an additional measure of the schools' economic and social contexts. The question used in ICCS 2009 is also included in the ICCS 2016 school questionnaire, with minor modifications.

Issues of social tension in the community: As part of the community within which it is located, the school may be affected by issues and problems existing at the community level. Issues of social tension within the local community may influence students' social relationships and the quality of their social lives and everyday experiences, both outside and inside the school (L'Homme, \& Jerez Henríquez, 2010). In addition to that, students' actual opportunities to volunteer or participate in civic-related activities in the communities may be influenced by the social climate existing in the local communities within which schools are located. A safe social environment is likely to enhance students' activities and participation in the local community. Conversely, issues creating social tensions and conflicts in the local community may discourage students' involvement in civic activities. In ICCS 2009, principals were asked about their perceptions of social tension in the community, and the results showed a negative association between higher levels of perceived social tension and students' civic knowledge (Schulz et al., 2010b, pp. 164-165). The ICCS 2016 school questionnaire includes a similar question, with minor modifications, to that used in the previous survey.

Students' participation in civic-related activities in the local community: Research has illustrated the importance of students' activities in the community and their reflection on them for the construction and the development of knowledge and skills for active citizenship (Annette, 2008; Henderson, Pancer, \& Brown, 2013). The links between the school and its community represent an opportunity for motivating student 
participation in activities related to civic and citizenship education, and for offering them opportunities for civic engagement. Schools' interactions with their local communities, and the links that have been established with other civic-related and political institutions, can also influence student perceptions of their relationship with the wider community and of the different roles they may play in it (Annette, 2000, 2008; Potter, 2002; Torney-Purta, \& Barber, 2004). ICCS 2009 showed that most of the students in almost all the participating countries had at least some opportunities to participate in such activities (Schulz et al., 2010b, pp. 154-155). The ICCS 2016 school questionnaire includes a modified form of the ICCS 2009 question about principals' perceptions of the opportunities students have to participate in activities carried out by the school in cooperation with external groups or organizations.

In ICCS 2009 the teacher questionnaire also included a question on student participation in civic-related activities in the local community, which was similar to the question included in the school questionnaire (Teachers' perceptions of student activities in the community). Results were generally consistent with those associated with principals' answers (Schulz et al., 2010b, pp. 152-153). Comparisons between the principals' and teachers' reports provide a broader picture of what schools actually do from different perspectives and viewpoints. The ICCS 2016 teacher questionnaire uses a similar question to that in the previous survey, which asks teachers whether they had participated with their students in activities in cooperation with external groups or organizations.

\subsection{The contexts of schools and classrooms}

As in the previous survey, ICCS 2016 considers students' learning outcomes in the field of civic and citizenship education not only as a result of teaching and learning processes, but also as the result of their daily experience at school. School experiences and their impact on learning outcomes are of particular importance in the context of civic and citizenship education, which is meant to develop learning outcomes that are not confined to the area of cognitive achievement, but also include attitudes and dispositions (Schulz et al., 2008) ${ }^{12}$. A large number of countries place emphasis on non-formal aspects of civic learning through participation and engagement or social interaction at schools (Ainley et al., 2013; Eurydice, 2005, 2012; Schulz et al., 2010b).

Students' experience at school not only depends on the teaching and learning developed at a classroom level, but also on the possibilities they have to experience the classroom and the school as a "democratic learning environment" (through participation at a school level, school and classroom climate, as well as the quality of the relationships within the school, between teacher and students, and among students) (Bäckman, \& Trafford, 2007; Huddleston, 2007; Trafford, 2003). The possibility of establishing and experiencing relationships and behaviors based on openness, mutual respect, and respect for diversity, as well as the possibility of giving and asserting personal opinions, allow students to practice a democratic lifestyle, to begin exercising their own autonomy, and to develop a sense of self-efficacy (see Mosher et al., 1994; Pasek et al., 2008). Recent research has also stressed the importance of informal learning at school for the development of students' active citizenship (Scheerens, 2009).

12 According to the UN resolution "Education for Democracy" (United Nations, 2012), schools are not only seen as responsible for delivering human rights education and citizenship curricula, but also for "extracurricular educational activities aimed at the promotion and consolidation of democratic values and democratic governance and human rights, taking into account innovative approaches and best practices in the field, in order to facilitate citizens' empowerment and participation in political life and policymaking at all levels." 
In view of the importance of school and classroom contexts for civic and citizenship education, ICCS 2016 makes use of the following types of questions:

- School questionnaire questions measuring principals' perceptions of school contexts and characteristics

- Teacher questionnaire questions about the background of teachers and their perceptions of school and classroom contexts

- Student questionnaire questions about students' perceptions of school and classroom contexts.

\subsubsection{School contexts and characteristics}

School climate generally refers to "the shared beliefs, the relations between individuals and groups in the organization, the physical surroundings, and the characteristics of individuals and groups participating in the organization" (Van Houtte, 2005, p. 85). In a civic and citizenship education context, school climate can be referred to as "impressions, beliefs, and expectations held by members of the school community about their school as a learning environment, their associated behavior, and the symbols and institutions that represent the patterned expressions of the behavior" (Homana, Barber, \& Torney-Purta, 2006, p. 3). A variety of learning situations can affect civic and citizenship education at schools. These include management, everyday activities within the school, the support for professional relationships inside the school itself, and the quality of links between the school and the outside community (Thapa, Cohen, Guffey, \& Higgins-D’Alessandro, 2013).

School climate also relates to the school culture and ethos that contribute to defining the school as a social organization, as well as distinguishing each individual school from others (Stoll, 1999). School culture refers to patterns of meaning that include norms, beliefs, and traditions shared by the members of the school community, and that contribute to shaping their thinking and the way they act (Stolp, 1994).

School climate and culture may contribute to the development among students and teachers of a sense of belonging to the school, thereby enhancing the commitment and motivation that these groups have toward improving school educational activities (Knowles, \& McCafferty-Wright, 2015). Participative governance practices contribute to characterizing the schools as democratic learning environments, and promoting teachers' participation in school governance helps the school to understand the variety of student learning needs and secure teachers' commitment to supporting school educational activities (Ranson, Farrell, Peim, \& Smith, 2005).

The ICCS 2016 school questionnaire includes a wide range of questions related to school climate, which measure principals' perceptions of teachers' and students' sense of belonging to the school, teachers', students' and parents' participation in decisionmaking processes, teachers' participation in school governance, the extent of bullying at school, and principals' reports on activities to prevent bullying.

Principals' perceptions of the engagement of the school community: Different styles of leadership and different strategies and procedures available to principals when exercising their role may also impact on the school climate and culture (Edmonds, 1979; Eurydice, 2013; Ishimaru, 2013; Marzano, 2003; Scheerens, Glas, \& Thomas, 2003; Sammons, Gu, Day, \& Ko, 2011). Therefore, a study of contexts for civic and citizenship education also needs to investigate how principals exercise their role in relation to the development 
of a democratic school environment, which is open to teachers', students', and parents' participation in decision-making processes (Torrance, 2013). ICCS 2016 includes a question on the extent to which teachers, parents and students are involved in decisionmaking processes. The School questionnaire also includes a question on principals' reports of students' participation as class representatives and in school elections that had been included in ICCS 2009.

Principals' perceptions of teacher participation in school governance: Empowering teachers to participate in decision-making at schools may contribute to active citizenship behavior within schools (Bogler, \& Somech, 2005). The ICCS 2009 school questionnaire included seven items concerned with principals' perceptions of teacher participation in school governance. These questions were intended to provide information about the extent to which teachers were willing to accept responsibilities beyond teaching. Using a modified question, the ICCS 2016 school questionnaire measures perceptions of principals regarding teachers' participation in school governance, teachers' support for maintaining good discipline, and teachers' willingness to become members of the school council.

Principals' perceptions of bullying at school: Bullying is defined as including aggressive behaviors intended to hurt someone either physically, emotionally, verbally or through the internet (AERA [American Educational Research Association], 2013; Olweus, 1973; Wade, \& Beran, 2011). In the ICCS 2016 school questionnaire, principals are asked to report on the frequency of aggressive behaviors they observe within the school.

Principals' reports on activities to prevent bullying: Schools are currently facing the problem of bullying both in the school context and in a cyber context (AERA, 2013; Corcoran, \& Mc Guckin, 2014). Research has shown that bullying shows considerable variation between classes within schools (Atria, Strohmeier, \& Spiel, 2007; Salmivalli, 2012). Although a "culture of silence" still persists among victims, activities to highlight bullying seem to have an impact, and may help to reduce bullying inside schools (Smith, \& Shu, 2000); prevention programs seem to have greater effect at the classroom level than at the school level (Kärnä et al., 2011). The school questionnaire includes a question on the initiatives implemented by schools intended to prevent bullying, including specific professional training aimed at the prevention of "cyberbullying" (Wade, \& Beran, 2011).

Principals' reports on activities related to environmental sustainability: Education for sustainable development (ESD), which aims at developing the learner's competence as a community member and global citizen, is increasingly viewed as an important aspect of citizenship education (Huckle, 2008). ESD is intended to be interdisciplinary and holistic, and therefore should be represented throughout the curriculum. In view of this aim, it is argued that it needs to involve the whole school community rather than just being a teacher-driven activity (Henderson, \& Tilbury, 2004). The ICCS 2016 school questionnaire includes questions on initiatives related to environmental sustainability. Principals are asked about the initiatives undertaken by the schools in order to become environments that respect the principles of sustainable development ("sustainable schools"; see Henderson, \& Tilbury, 2004) and to enable students to experience these principles directly (for example, through school initiatives to save energy, to reduce and separate waste, to purchase environmentally-friendly items, and, more generally, to encourage students' environmental-friendly behaviors). 
Principals' reports of students' access to ICT and to internet for their learning activities: The rapid increase in usage of internet and new social media in youth has several important educational implications. Formal education in new social media literacy has been shown to increase civic participation and provide students with access to diverse viewpoints (Kahne, 2010). In view of this development, ICCS 2016 also investigates the school context for students' use of social media for civic engagement. The school questionnaire collects information about the technological resources available at school and about the actual access students have to them.

Principals' reports on the delivery of civic and citizenship education at school: Many studies have shown that approaches to civic and citizenship education vary considerably across countries (Ainley et al., 2013; Birzea et al., 2004; Cox et al., 2005; Eurydice, 2005, 2012). Furthermore, ICCS 2009 results illustrated that different approaches to this learning area may actually coexist within the same schools (Schulz et al., 2010b, pp. 178-179). Principals from schools surveyed in ICCS 2009 provided interesting information on how they rated the most important aims of civic and citizenship education. Results showed notable differences across participating countries and that, generally, school principals regarded the most relevant aims of civic and citizenship education to be those related to the development of knowledge and skills (Schulz et al., 2010b, pp. 184185). As in the previous survey cycle, the ICCS 2016 school questionnaire includes a set of questions on principals' reports about the way civic and citizenship education is delivered at their schools, on their perceptions of the importance of the aims of civic and citizenship education, and how specific responsibilities for civic and citizenship education are assigned within their schools.

Principals' reports on school autonomy for the delivery of civic and citizenship education: The school improvement literature shows that enabling some degree of autonomy favors the success of improvement efforts (Reezigt, \& Creemers, 2005). The level of autonomy possessed by schools may influence the way civic and citizenship education is delivered at a school level (curriculum planning, choice of textbooks and teaching materials, assessment procedures and tools). The existence of national legislation, regulations and standards concerning the results that students should achieve does not necessarily imply that schools deliver similar programs and approaches to teaching (Eurydice, 2007). The time allocated to citizenship education, teacher qualifications, and the support the principals provide to civic and citizenship education within schools may vary (Keating, \& Kerr, 2013; Keating, Kerr, Benton, Mundy, \& Lopes, 2010). The ICCS 2016 school questionnaire includes a question about the schools' autonomy to select textbooks, instigate student assessment procedures, plan curriculum, activities and projects related to civic and citizenship education, and implement teacher training.

Principals' report on school characteristics: School resources consist of both material and human resources, and there is no consensus on the extent to which these school resources can contribute to school development and improvement (Hanushek, 1994, 1997, 2006). The ICCS 2009 school questionnaire included questions about the demographic characteristics of schools (public/private school, number of students, number of target grade students, and number of teachers). Research has shown associations between these characteristics and learning outcomes (Anderson, Ryan, \& Shapiro, 1989). In the analysis for the ICCS 2009 Latin American report, statistically significant differences in civic knowledge between public and private schools were found in some countries, even after controlling for the socioeconomic context (Schulz, Ainley, Friedman, \& Lietz, 
2011, p. 73). As in the previous survey, the ICCS 2016 school questionnaire includes questions related to school characteristics like private or public school management, and the number of male and female students at school (overall and enrolled in the target grade).

Principals' perceptions of students' backgrounds: Research has emphasized the importance of the average socioeconomic family background of students at the level of individual schools (see, for example, Sirin, 2005). To capture the "social intake", the ICCS 2016 school questionnaire includes a question adopted from PIRLS 2011 (Mullis, Martin, Kennedy, Trong, \& Sainsbury, 2009) that asked school principals to provide approximate percentages of students from economically disadvantaged or affluent homes.

\subsubsection{Teacher background and their perceptions of schools and classrooms}

The ICCS 2016 teacher questionnaire is administered to all teachers teaching at each country target grade regardless of their subject area. It is designed to capture the background of teachers, as well as a wide range of perceptions of school and classroom contexts. As in ICCS 2009, the ICCS 2016 teacher questionnaire includes an international option, with questions about civic and citizenship education at school and on the teaching practices actually adopted in this learning area. This part of the questionnaire is only completed by teachers of subjects related to civic and citizenship education.

Teachers' reports on their background characteristics: Similar to ICCS 2009, the ICCS 2016 teacher questionnaire includes a set of items asking about teachers' demographic variables (gender, age) and the subject/s taught in general and at the target grade.

Teachers' participation in school governance: Teacher participation in school governance can be regarded as part of democratic governance processes at school and as a factor that can contribute to the characterization of the school as a democratic learning environment (Council of Europe, 2007). The ICCS 2009 teacher questionnaire comprised a set of seven items asking teachers about their participation in school governance. The items of the questions are the same as those included in the parallel question of the school questionnaire and formed a scale that was included in the international database. A similar question composed of five items is included in the 2016 teacher questionnaire. The items refer to teacher willingness to take on responsibilities besides teaching, and their reflections on the extent to which they are willing to cooperate with other teachers, cooperate to solve conflicts within the school, and engage in guidance and counseling activities.

Teachers' perceptions of bullying at school: Teacher behaviour has been identified as an explanatory variable of bullying at schools (Roland, \& Galloway, 2002), which may be related to their function as role models and authorities in classroom interactions (Verkuyten, \& Thijs 2002). The teacher questionnaire includes a question, which is (in a slightly modified version) also included in the school questionnaire, and is designed to capture teachers' perceptions of bullying within the school (Olweus, 1973).

Teachers' perceptions of school climate: The school climate and the quality of the relations within the school (student-teacher relations and student-student relations) may influence student academic achievement (Bear, Yang, Pell, \& Gaskins, 2014) and may also be associated with bullying at school (Powell, Powell, \& Petrosko, 2015). The ICCS 
2009 teacher questionnaire included two sets of items related to teachers' perceptions of school climate. The items referred to teachers' perceptions of student behaviors at school and to teachers' perceptions of social problems at school. Both questions are also included in the 2016 teacher questionnaire.

Teachers' perceptions of classroom climate: Classroom climate is a general concept, where definitions focus mainly on the level of cooperation in teaching and learning activities, fairness of grading, and social support. Democratic classroom climate focuses mainly on the implementation of democratic and liberal values in the classroom (Ehman, 1980; Hahn, 1999). A democratic classroom climate may help students in understanding the advantages of democratic values and practices, and may have a positive effect on their active assimilation (Perliger, Canetti-Nisim, \& Pedahzur, 2006). As some studies have pointed out, aside from teachers' perceptions, what critically matters are the students' perceptions of classroom climate (Hooghe, \& Quintelier, 2013). The ICCS 2009 teacher questionnaire included a set of items asking teachers about their perception of classroom climate and about students' participation in classroom activities. The four items formed a scale that was included in the ICCS 2009 database. Results showed positive associations with civic knowledge in a number of countries (Schulz et al., 2010b, p. 173). The question is also included in the ICCS 2016 teacher questionnaire.

Teachers' perceptions of activities related to environmental sustainability: As in the ICCS 2016 school questionnaire, the teacher questionnaire includes a question that asks about teachers' involvement in initiatives and programs related to environmental sustainability (Kyburz-Graber, 2013; Lundholm, Hopwood, \& Kelsey, 2013; UNESCO, 2012a). The items included in the question are related to activities that enhance students direct involvement and engagement both within the school and in the local community, as well as their awareness of the impact of their behaviors on environment.

Teachers' perceptions of the delivery of civic and citizenship education at school: The ICCS 2009 teacher questionnaire included two set of items related to the way civic and citizenship education is delivered at the school level. The two questions asked teachers about their perceptions of the importance of the aims of civic and citizenship education, and about how specific responsibilities for civic and citizenship education are assigned within the school. With respect to the importance of different aims of civic and citizenship education, results were very similar to those of the school questionnaire (Schulz et al., 2010b, pp. 182-183). ICCS 2016 includes slightly modified questions related to the aims of civic and citizenship education in both teacher and school questionnaires.

Teachers' perceptions of ICT use for teaching and learning: Research has shown widespread use of ICT in secondary education, as well as considerable differences in the equipment of schools with ICT resources (see Fraillon, Ainley, Schulz, Friedman, \& Gebhardt, 2014). ICCS 2016 asks teachers to indicate whether and to what extent their schools provide them with a set of electronic devices with an internet connection that they can use for their teaching activities at the target grade. A similar question (with a focus on resource provisions) is also included in the school questionnaire.

Teachers' perceptions of their teaching of subjects related to civic and citizenship education: Studies have shown that teacher preparation is one of the most important factors influencing student achievement (see OECD, 2009, 2014b). With regard to civic and citizenship education, teacher training is a particular challenge for educational policies, 
and in many countries no specific training is provided to teachers in this area (Birzea et al., 2004; Eurydice, 2005, 2012). Following a classification developed by Shulman $(1986,1987)$, teacher knowledge may relate to topics related to civic and citizenship education (content knowledge), or to teaching methods and approaches (pedagogical knowledge). Furthermore, there are a wide range of teaching approaches in this learning area (Munn, Brown, \& Ross, 2012). Results from ICCS 2009 showed that teachers of civic-related subjects tended to be most confident about teaching citizens' rights and responsibilities and human rights, while they were less confident in teaching topics related to the economy, business and legal institutions (Schulz et al., 2010b). Also using questions that are identical to questions from the ICCS 2009, the section of the ICCS 2016 teacher questionnaire administered to teachers who teach subjects related to civic and citizenship education collects data on the following aspects:

- Teachers' reports about the planning of civic and citizenship education (use of different sources) and about teaching and learning activities (such as "interactive teaching", "traditional" teaching, and discussion of controversial issues in classrooms).

- Teachers' reports on the use of different assessment tools in their teaching of civic and citizenship education.

- Teachers' preparation in teaching civic and citizenship related topics.

- Teachers' perceptions of possible improvements to the teaching of civic and citizenship education at their schools.

- Teachers' reports on their preparation and in-service training on topics relating to civic and citizenship education (content knowledge) or teaching methods and approaches.

\subsubsection{Student perceptions of the context of schools and classrooms}

Students' perceptions of the school and classroom context encompass the classroom climate for civic and citizenship education, student reports on their civic learning experiences, students' experience with verbal and physical abuse, and students' perceptions of school climate.

Classroom climate for civic and citizenship education at school: The CIVED survey included a set of items measuring students' perceptions of what happened in their civic education classes. Six items were used to measure an index of open climate for classroom discussion (see Schulz, 2004) that had earlier been identified as a positive predictor of civic knowledge, and students' expectations to vote as an adult (Torney-Purta et al., 2001). The ICCS 2009 survey used a similar instrument that measured students' perceptions of what happens in their classrooms during discussions of political and social issues. Results of multivariate analyses confirmed the association of this construct with civic-related learning outcomes (Schulz et al., 2010b). The ICCS 2016 student questionnaire includes a question with six items from ICCS 2009, designed to measure students' perceptions of an open classroom climate for discussion of civic issues.

Students' reports on learning experiences regarding civic issues: CIVED 1999 asked students to report how much they had learned about civic issues at school. Students' answers to how much they had learned about the importance of voting at school were used as a (positive) predictor to explain variation in expected participation in elections (Torney-Purta et al., 2001). The ICCS 2016 student questionnaire includes a new question asking students to assess how much they have learned in school about seven different political or social issues. 
Students' perceptions of opportunities to learn about civic issues related to Europe: The European regional questionnaire of ICCS 2009 asked students about the opportunities they had to learn about Europe at school, and results showed that majorities of students across participating countries reported learning about a wide range of issues (Kerr et al., 2010). The European regional questionnaire for ICCS 2016 includes a modified question designed to measure the extent of the opportunities given to students to learn about civic issues related to Europe.

Students' perceptions of school climate: School climate is widely regarded as an important factor in explaining student learning outcomes (Bryk, Sebring, Allensworth, Easton, \& Leppescu, 2010; Wang, \& Degol, 2015). Scheerens and Bosker (1997) viewed school climate as a synonym for a school culture that manifests a range of variables centered on student engagement, student absenteeism, student conduct and behavior, staff motivation, and the relationships among students, teachers, and the school itself. More recent conceptions characterize school climate as being made up of four aspects: academic climate and the prioritizing of successful learning, interpersonal relationships within the school and with parents, physical and emotional safety, and organizational effectiveness (Wang, \& Degol, 2015). The importance of a positive school climate for engaging students in civic-related learning experiences has also been emphasized in research about civic learning (see for example, Homana et al., 2006). The ICCS 2009 student questionnaire included a set of two items measuring students' perceptions of school and five items measuring students' perceptions of student-teacher relationships at school. ICCS 2016 includes five items (four of them had been used in the previous survey) designed to capture students' perceptions of student-teacher relationships at school, three additional items to gauge students' perceptions of social interaction between students at their school, and one item reflecting students' perception of the risk of being bullied at school.

Students' reports on personal experiences of bullying and abuse: One symptom of social disintegration and dysfunctional social interaction at school is "bullying", which has been discussed in research since the 1970s (Olweus, 1973). Bullying has continued to be a focus for educational researchers as well as practitioners (Goldsmid, \& Howie, 2014; Smith, 2004; Ttofi, \& Farrington, 2011), and the emergence of "cyber bullying" has raised awareness of bullying even further. Bullying has also been identified as a factor affecting school perceptions (Bayar, \& Uçanok, 2012). The Latin American questionnaire in ICCS 2009 included items measuring students' experience of verbal or physical aggression at school, and results showed that, in the participating countries in this region, many students reported physical aggression in their school environment (Schulz, Ainley, Friedman, \& Lietz, 2011). The international student questionnaire for ICCS 2016 will ask students about the level of verbal or physical abuse faced by students at school using a set of six items.

\subsection{The home and peer context}

The home and peer contexts and characteristics that can influence the development of young people's knowledge, attitudes, and beliefs in the context of civics and citizenship are considerable. They include family- and peer-group interactions, educational resources in the home, culture, religion, values, use of the test language at home, the relationship status the young person has within the family, parental education, incomes and employment levels, access to different kinds of media, the quality of the school- 
home connections, and the wide range of civic-related opportunities out of school that the young person can exercise. Among all of these, family background tends to be particularly emphasized as a likely influence on learning outcomes in general, as well as related to civic and citizenship education.

Research findings have highlighted the importance of family background for the development of dispositions toward engagement by and participation of young people (Bengston, Biblarz, \& Roberts, 2002; Janoski, \& Wilson, 1995; Lauglo, 2011; Renshon, 1975; Grusec, \& Kuczynski, 1997; Vollebergh, Iedema, \& Raaijmakers, 2001). There is a general consensus that family background is an influential variable in the political development of adolescents (Sherrod, Torney-Purta, \& Flanagan, 2010). The role of socioeconomic background can be seen as influential in (i) providing a more stimulating environment, and (ii) enhancing the educational attainment and future prospects of adolescents, factors that, in turn, foster political involvement as an individual resource.

Studies of political socialization and participation emphasize the importance of the extent to which families and individuals can access different forms of capital. Bourdieu (1986) saw economic capital as the sources of other forms of capital, and distinguished between human, cultural, and social capital. Whereas human capital refers to an individual's skills, knowledge, and qualifications, cultural capital refers to those "widely shared, high-status cultural signals (attitudes, preferences, formal knowledge, and behaviors) used for social and cultural exclusion" (Lamont, \& Lareau, 1988, p. 156). Social capital is conceptualized as a societal resource that links citizens to one another so that they can achieve goals more effectively (see Stolle, 2002).

In his study of institutional performance in Italy, Putnam (1993, p. 185) regarded social capital as the "key to making democracy work." His conceptual view built on Coleman's (1988) concept of social capital as being generated by the relational structure of interactions inside and outside the family, and facilitating the success of an individual's actions and also their learning outcomes. ${ }^{13}$ According to Putnam (1993), three components of social capital (social trust, social norms, and social networks) form a "virtuous cycle" that provides a context for successful cooperation and participation in a society.

Social capital research has used a varying range of different factors, including socioeconomic status, personal networks, membership of organizations, interpersonal trust, and personal communication (media, or discussions). Consequently, the concept of social capital has often been criticized for its lack of clarity and the problems it presents in terms of finding suitable indicators (Woolcock, 2001).

Within the context of ICCS, the concept of social capital is viewed as helpful in that it describes mechanisms that explain why some students have higher levels of civic knowledge and engagement than others. Measures of different aspects of social capital (trust, norms, and social interaction) include attitudinal and background variables. Some variables reflecting social capital are related to the home environment, in particular interactions with parents, peers, and media. Other variables relevant in this context are measures of interpersonal trust and voluntary participation in civic-related organizations (see the Civic and Citizenship Framework in section 2).

13 Putnam's view of social capital, however, is narrower and more specific than Coleman's concept. Putnam saw social capital as a collective resource and stated that horizontal interactions tend to foster trust and participation, whereas vertical relationships lead to distrust and disengagement (Stolle, \& Lewis, 2002). 
Variables related to the home environment that are antecedents of student learning and development and are measured through the student background questionnaire include (i) parental socioeconomic status, (ii) cultural and ethnic background, (iii) parental interest in political and social issues, and (iv) family composition. The ICCS 2016 student background questionnaire also collects data on process-related variables that reflect social interactions outside of school (for example, discussing political and social issues with parents and peers, as well as accessing media information).

Students' parental socioeconomic background: Socioeconomic status (SES) is widely regarded as an important explanatory factor that influences learning outcomes in many different and complex ways (Sirin, 2005). There is a general consensus that socioeconomic status is represented by income, education, and occupation (Gottfried, 1985; Hauser, 1994) and that using all three variables is better than using only one (White, 1982). However, there is no consensus among researchers regarding which measures should be used in any one analysis (Entwistle, \& Astone, 1994; Hauser, 1994). In international studies, additional caveats imposed on the validity of background measures and the cross-national comparability of family background measures present ongoing challenges for researchers in this area (see Buchmann, 2002; Brese, \& Mirazchiyski, 2013; Caro, \& Cortés, 2012).

As in the previous survey, the student questionnaire for ICCS 2016 includes three different types of measures:

- Data on parental occupation are collected through open-ended student reports on mother's and father's jobs and coded according to the International Standard Classification of Occupations (ISCO-2008) framework (International Labour Organisation, 2007). Subsequently, the codes will be scored using the international socioeconomic index (SEI) of occupational status, in order to obtain measures of socioeconomic status (Ganzeboom, de Graaf, \& Treiman, 1992).

- Data on parental education are collected through closed questions in which educational levels are defined by the International Standard Classification of Education (ISCED-2011) (UNESCO, 2012b) and then adapted to the national context.

- Data on home literacy environment are collected through a question about the number of books at home.

Given the increasing importance of ICT for civic engagement, the ICCS 2016 student questionnaire also includes questions about the availability of electronic devices and household access to the internet. Data derived from these questions will also provide additional indicators of socioeconomic background (see Fraillon et al., 2014).

Students' cultural/ethnic background: International studies confirm differences in achievement for reading and mathematics depending on language and immigrant status (see, for example, Elley, 1992; Mullis et al., 2000; Stanat, \& Christensen, 2006). Students from immigrant families, especially among those who have arrived recently, tend to lack proficiency in the language of instruction and to be unfamiliar with the cultural norms of the dominant culture. Furthermore, ethnic minorities often have a lower SES, which correlates highly with learning and engagement; there is also evidence that immigrant status, ethnic background and language have effects on different students' learning outcomes even after controlling for other background variables (see for example, Fuligni, 1997; Kao, 2001; Lehmann, 1996; Stanat, \& Christensen, 2006). 
Results from ICCS 2009 showed that immigrant background and language use were both associated with civic-related learning outcomes, in particular in countries with larger proportions of immigration (see Schulz et al., 2010b). As in the previous survey, the ICCS 2016 student questionnaire includes the questions regarding the following cultural and ethnic background characteristics in its student questionnaire:

- Country of birth (mother, father, and student): This information was used to distinguish "native," "first-generation" (parents born abroad, but student born in country), and "immigrant" (student and parents born abroad) students.

- Language of use at home (language of assessment versus other languages).

- Student self-reports on ethnicity (optional for countries).

Students' parental interest: There is evidence that young people whose parents engage with them in discussions about politics and civic issues tend to have higher levels of civic knowledge and engagement (see, for example, Lauglo and Øia, 2006). The ICCS 2009 survey asked students to assess the extent of their parents interest in political and social issues, and results showed positive associations with some students' learning outcomes, in particular those related to expected political engagement as adults (Schulz et al., 2010b; Schulz, Ainley, \& Fraillon, 2015). ICCS 2016 includes the same question, complemented by an item measuring the students' own interest in political and social issues.

Students' reports of family composition: Family structure represents an important factor of socialization that may affect learning outcomes. For example, research in the United States has shown that students from single-parent families perform less well than those from two-parent households, a finding which has been associated with economic stress, and lack of human or social capital in the household (McLanahan, \& Sandefur, 1994; Seltzer, 1994). However, the effects of single-parent upbringing on learning outcomes have been generally considered as relatively small (for a review, see Ginther, \& Pollak, 2004; Marjoribanks, 1997). Using a question that was optional for countries, ICCS 2009 measured family structure by asking students about the composition of their respective household, that is, parents, guardians, siblings, relatives, and/or other persons. The same question is included as an international option in the ICCS 2016 student questionnaire.

Students' discussion of political and social issues with parents and peers: Analysis of CIVED data showed that frequency of political discussions is a positive predictor of both feelings of efficacy and expected participation (see, for example, Richardson, 2003). Similar results were found in a comparative study of secondary students in 15 countries that participated in CIVED (Schulz, 2005), and ICCS 2009 data suggested associations between the frequency of participation in discussions about political and social issues and civic knowledge, as well as civic interest (Schulz et al., 2010b). The ICCS 2016 student questionnaire measures students' discussions of political and social issues with parents and peers using the same items as in the previous survey cycle.

Students' use of media for information on political and social issues: One popular explanation for the waning of civil society in the United States is the negative effect of television viewing (Putnam, 2000), which leads to decreasing interest, sense of efficacy, trust, and participation (see also Gerbner, 1980; Robinson, 1976). However, research also shows that media use (in particular for information) is usually positively related to political participation. For example, Norris (2000) concluded from an extensive literature review and findings from a large-scale study that there was no conclusive evidence for 
a negative relationship between media use and political participation. CIVED showed that media information obtained from television news reports was a positive predictor for civic knowledge and expected participation in elections (Torney-Purta et al., 2001). ICCS 2009 also showed that students' civic knowledge was positively associated with viewing television news, and reading newspapers, and getting information from the internet (Schulz et al., 2010b). As in the previous survey cycle, the student questionnaire for ICCS 2016 includes a number of items measuring the frequency of students' use of media to obtain information about political and social issues.

Students' participation in religious services: Researchers have suggested that religious affiliation may help to foster political and social engagement (see Guo, Webb, Abzug, \& Peck, 2013; Perks, \& Haan, 2011; Verba et al., 1995), because religious organizations provide networks focused on political recruitment and motivation. However, there is also evidence for negative effects of religious affiliation on democratic citizenship, as reflected in lower levels of political knowledge and feelings of efficacy among strongly religious people (Scheufele, Nisbet, \& Brossard, 2003). In the case of young people, religious affiliation and participation can be seen as part of the home environment that may influence the process of civic-related learning. As part of its international option about religion, ICCS 2016 asks students about the frequency of their attendance of religious services using the same question as in the previous survey cycle.

\subsection{Student characteristics}

Individual students' development of understandings, attitudes, and dispositions can be influenced by a number of characteristics, some of which link to family background. Antecedents at this level, collected through the student questionnaire, include the student characteristics of age, gender, and expected educational qualifications.

Students' age: Research has found that, during adolescence, civic knowledge and (at least some forms of) engagement increase with age (Amadeo et al., 2002; Hess, \& Torney, 1967). However, there is also evidence that feelings of trust in the responsiveness of institutions and willingness to engage in conventional forms of active political participation decrease toward the end of secondary school (Schulz, 2005). ICCS 2009 confirmed earlier cross-sectional research based on grade sample data, which showed age to be negatively correlated with students' civic knowledge, in particular in countries with higher rates of grade repetition, because the students in the class who are older are typically those who have repeated a grade because of previous low achievement (Schulz et al., 2010b). As in the previous survey cycle, the student questionnaire asks students about their month and year of birth.

Students' sex (male, female): The first IEA Civic Education Study in 1971 found considerable gender differences regarding cognitive achievement, with males tending to have the higher civic knowledge scores (Torney et al., 1975). The IEA's 1999 CIVED survey, however, presented a different picture: whereas in some countries males showed (slightly and not significantly) higher average scores, in other countries females were performing better (although only one country reported the difference as significant). Interestingly, greater gender differences in favor of males were found in the follow-up study of upper secondary students (Amadeo et al., 2002). ICCS 2009 showed a gender gap in favor of female students (Schulz et al., 2010b), a change from CIVED 1999 that might also be explained by the broadening of the underlying assessment framework with its emphasis on aspects of reasoning. 
CIVED also showed that gender differences were usually larger with regard to indicators of civic engagement: in most countries, males tended to have higher levels of political interest and expected participation. Gender differences were also important with regard to attitudes toward immigrants' and women's rights (Amadeo et al., 2002; Torney-Purta et al., 2001). ICCS 2009 confirmed these findings and showed gender differences for a wide range of indicators of civic attitudes and indicators of engagement (Fraillon et al., 2014; Kerr et al., 2010; Schulz et al., 2010b, ; Schulz, Ainley, Friedman, \& Lietz, 2011). As in the previous survey cycle, the ICCS 2016 student questionnaire will ask about the students' sex (male, female).

Students' expected educational attainment: In the first two IEA studies on civic education, expected years of future education were important predictors of civic knowledge (Amadeo et al., 2002; Torney et al., 2001). This variable reflects individual aspirations. However, responses can also be influenced by parent or peer expectations and/or, in some education systems, by limitations brought about by students studying in programs that do not give access to university studies. ICCS 2009 data used a similar question that asked students to indicate their expected level of education. Results from this survey confirmed that this variable is positively associated with civic knowledge (Schulz et al., 2010b, pp. 225-232). As in the previous survey cycle, the ICCS 2016 student questionnaire asks about students' expected educational attainment.

Open Access This chapter is distributed under the terms of the Creative Commons AttributionNonCommercial 4.0 International License (http://creativecommons.org/licenses/by-nc/4.0/), which permits any noncommercial use, duplication, adaptation, distribution and reproduction in any medium or format, as long as you give appropriate credit to the original author(s) and the source, provide a link to the Creative Commons license and indicate if changes were made.

The images or other third party material in this chapter are included in the works Creative Commons license, unless indicated otherwise in the credit line; if such material is not included in the works Creative Commons license and the respective action is not permitted by statutory regulation, users will need to obtain permission from the license holder to duplicate, adapt or reproduce the material. 


\section{Assessment Design}

\subsection{The ICCS 2016 instruments}

The ICCS 2016 instruments collect data relative to outcome, as well as contextual variables. Given the specific nature of a study on civic and citizenship education, outcome variables are assessed through cognitive test materials and a student questionnaire. Contextual data that explain variation in outcome variables are collected through student, teacher, and school questionnaires, as well as through the national contexts survey.

Table 4.1 lists the instruments administered as part of the ICCS 2016 survey, their approximate administration times, and their respondents. The student assessment instrument consists of two parts: (i) an international core, including the cognitive test and the student questionnaire; and (ii) an optional regional questionnaire for European and Latin American countries.

Table 4.1: ICCS 2016 instruments

\begin{tabular}{l|c|c}
\hline Instrument & Length & Respondent \\
\hline International cognitive test & $45 \mathrm{~min}$. & Student \\
\hline International student questionnaire & $40 \mathrm{~min}$. & Student \\
\hline Regional module instrument & $\sim 15 \mathrm{~min}$. & Student \\
\hline Teacher questionnaire & $\sim 30 \mathrm{~min}$. & Teacher \\
\hline School questionnaire & $\sim 30 \mathrm{~min}$. & Principal \\
\hline National contexts survey & $\mathrm{N} / \mathrm{A}$ & NRC \\
\hline
\end{tabular}

Note: $\mathrm{N} / \mathrm{A}=$ not applicable; $\mathrm{NRC}=$ national research coordinator or designate.

Test items from four clusters included in ICCS 2009 are used to estimate changes over time for those countries participating in both surveys. They are integrated across all eight ICCS 2016 test item clusters to ensure an appropriate content balance across content and cognitive domains within each cluster.

The student, teacher and school questionnaires also include larger numbers of items reflecting aspects that were also measured in ICCS 2009 through identical or slightly modified sets of items.

Table 4.2 records the numbers and respective percentages of ICCS 2009 and newly developed items for each of the main survey instruments. In the student test and the school questionnaire, about half of the item material was newly developed. This proportion is lower in the international student and teacher questionnaires, where only about one-third of the material was added. The European regional student questionnaire includes 70 percent of new item material, while this percentage is much lower in the Latin American regional student questionnaire, for which four-fifths of the items were retained from ICCS 2009. 
Table 4.2: Numbers and percentages of ICCS 2009 and newly developed items in the ICCS 2016 main survey instruments

\begin{tabular}{l|rl|rr|r}
\hline Instruments & \multicolumn{2}{|c|}{$\begin{array}{c}\text { ICCS 2009 } \\
\text { items }\end{array}$} & \multicolumn{2}{|c|}{$\begin{array}{c}\text { ICCS 2016 } \\
\text { items }\end{array}$} & Total \\
\hline International student test & 42 & $(48 \%)$ & 46 & $(52 \%)$ & 88 \\
\hline International student questionnaire & 115 & $(64 \%)$ & 64 & $(36 \%)$ & 179 \\
\hline European student questionnaire & 21 & $(30 \%)$ & 50 & $(70 \%)$ & 71 \\
\hline Latin American student questionnaire & 55 & $(79 \%)$ & 15 & $(21 \%)$ & 70 \\
\hline Teacher questionnaire & 49 & $(66 \%)$ & 25 & $(34 \%)$ & 74 \\
\hline School questionnaire & 57 & $(54 \%)$ & 49 & $(46 \%)$ & 106 \\
\hline
\end{tabular}

Note: The table does not include optional questionnaire items.

\subsection{Item types}

The ICCS 2016 instruments include a range of different item types in order to assess a diversity of cognitive, affective-behavioral or contextual aspects.

The cognitive test is expected to contain the following two item types:

- Multiple-choice (MC): Each item has four response options, one of which is the correct response and the other three of which are distracters.

- Open-ended response (OR): Students are requested to write a short response to an open-ended question. The responses are scored by scorers working for the national centers.

As in the previous survey, most test items have a multiple-choice format, while a small proportion of the items (about 10\%) are open-ended response items. Differing qualities of student knowledge and reasoning will be evaluated across the full item set by using items with a range of difficulties, and within selected constructed response items through the application of a partial-credit scoring guide to students' responses. Student responses to each of these items can be assessed according to the level of sophistication demonstrated against a hierarchy of distinct substantive categories that relate to the fixed context within the item. Typically, test questions are organized in units in which the content of all items refers to a stimulus describing a particular situation or problem, in a few cases accompanied by a graphic.

As in ICCS 2009, the student, teacher, and school questionnaires for ICCS 2016 include the following item types:

- Likert-type items: For each item, respondents are asked to rate a number of statements, typically on a four-point scale. For most of these items, the rating scale ranges from (1) strongly agree to (4) strongly disagree. The rating scales for other questions indicate frequencies (never, rarely, sometimes, often) or levels of interest, trust, or importance.

- Multiple-response items: Respondents are asked to indicate the three aspects they view as most important.

- Categorical response items: Respondents are required to choose one out of two or more response categories that they view as most appropriate. These questions are primarily used for collecting contextual information (for example, on gender, 
educational level of parents, books in the home, subjects taught at school, and public or private school management).

- Open-response items: Respondents are asked to write a short response that is coded by the national centers; these items are used only for collecting information on parental occupation.

\subsection{Coverage of framework domains}

The ICCS 2016 main survey instruments were developed to cover the cognitive, affectivebehavioral and content domains defined in the civics and citizenship framework. Table 4.3 illustrates the number of items in student test and questionnaire instruments relating to the framework domains. The numbers of attitude items included in the regional questionnaire for European and Latin American countries are presented in separate rows. Test and questionnaire items in ICCS 2009 and ICCS 2016 were developed to address aspects related to all cognitive, affective-behavioral and content domains, Table 4.3 shows that items are not evenly spread across all cells in the table.

As in ICCS 2009, about three quarters of the test items pertain to the cognitive domain analyzing and reasoning, and most test items of the cognitive domain knowing relate to the content domain civic society and systems. The content domain receiving least coverage in the cognitive test is civic identities with only four out of 88 items, which resembles the representation of this content domain in the ICCS 2009 test.

Among affective-behavioral items in the international student questionnaire, about three fifths measure attitudes and two fifths were designed to collect data on student engagement. The European and Latin American regional questionnaires only include items related to the affective-behavioral domain attitudes. Across international and regional instruments, about a third of affective-behavioral items relates to the contents domain civic society and systems, and another third to civic principles. About a quarter of these items pertain to civic participation while one tenth relates to civic identities.

Table 4.3: Coverage of the cognitive, affective-behavioral and content domains

\begin{tabular}{|c|c|c|c|c|c|}
\hline & \multicolumn{4}{|c|}{ Content domains } & \multirow[b]{2}{*}{ Total } \\
\hline & $\begin{array}{c}\text { Civic } \\
\text { Society and } \\
\text { systems }\end{array}$ & $\begin{array}{c}\text { Civic } \\
\text { principles }\end{array}$ & $\begin{array}{c}\text { Civic } \\
\text { participation }\end{array}$ & $\begin{array}{c}\text { Civic } \\
\text { identities }\end{array}$ & \\
\hline \multicolumn{6}{|l|}{ Cognitive domains } \\
\hline Knowing & 12 & 9 & 2 & 0 & 23 \\
\hline Reasoning and applying & 24 & 18 & 19 & 4 & 65 \\
\hline Total & 36 & 27 & 21 & 4 & 88 \\
\hline \multicolumn{6}{|c|}{ Affective-behavioral domains } \\
\hline Attitudes & 42 & 21 & 5 & 5 & 73 \\
\hline Engagement & 5 & 8 & 35 & 2 & 50 \\
\hline $\begin{array}{l}\text { Attitudes (in the European } \\
\text { questionnaire) }\end{array}$ & 21 & 22 & 6 & 9 & 58 \\
\hline $\begin{array}{l}\text { Attitudes (in the Latin } \\
\text { American questionnaire) }\end{array}$ & 11 & 35 & 16 & 8 & 70 \\
\hline Total & 79 & 86 & 62 & 24 & 251 \\
\hline
\end{tabular}

Note: The table does not include optional questionnaire items. 


\subsection{The ICCS 2016 test design and the described achievement scale}

For the student test, ICCS 2016 uses a rotated design for test administration, making it possible to include more test material and thus ensure greater coverage of the assessment framework without increasing the testing time for each student. This procedure also enables a sufficient number of score points to be generated to provide the basis for comprehensive descriptions of the scale. Rotating the clusters throughout the booklets ensures that the different tests are linked.

Table 4.4 shows the test booklet design for the ICCS 2016 main survey. All eight clusters contain ICCS 2009 items. The booklet design is balanced to the extent that each cluster appears in three booklets in three different positions (A, B and C).

Table 4.4: Main survey test booklet design

\begin{tabular}{c|c|c|c}
\hline \multirow{2}{*}{ Booklet } & \multicolumn{3}{|c}{ Posittion } \\
\cline { 2 - 4 } & $\mathrm{A}$ & $\mathrm{B}$ & $\mathrm{C}$ \\
\hline 1 & $\mathrm{C} 01$ & $\mathrm{C} 02$ & $\mathrm{C} 04$ \\
\hline 2 & $\mathrm{C} 02$ & $\mathrm{C} 03$ & $\mathrm{C} 05$ \\
\hline 3 & $\mathrm{C} 03$ & $\mathrm{C} 04$ & $\mathrm{C} 06$ \\
\hline 4 & $\mathrm{C} 04$ & $\mathrm{C} 05$ & $\mathrm{C} 07$ \\
\hline 5 & $\mathrm{C} 05$ & $\mathrm{C} 06$ & $\mathrm{C} 08$ \\
\hline 6 & $\mathrm{C} 06$ & $\mathrm{C} 07$ & $\mathrm{C} 01$ \\
\hline 7 & $\mathrm{C} 07$ & $\mathrm{C} 08$ & $\mathrm{C} 02$ \\
\hline 8 & $\mathrm{C} 08$ & $\mathrm{C} 01$ & $\mathrm{C} 03$ \\
\hline
\end{tabular}

Test items will be scaled using IRT (item response theory) (Hambleton, Swaminathan, \& Rogers, 1991; Rasch, 1960). The cognitive test items will be scaled to obtain scores of civic knowledge and understanding. The scale will cover student knowledge and understanding encompassing the four content domains (civic systems and society, civic principles, civic participation, and civic identities) and the two cognitive domains (knowing and applying and reasoning). Items will be used to describe student knowledge and understandings at different levels of student proficiency.

As in the previous survey cycle, test items were designed to provide the basis for deriving a described scale of civic knowledge, which consists of three levels of proficiency. The proficiency-level descriptions are syntheses of the item descriptors within each level. They describe a hierarchy of civic knowledge in terms of increasing sophistication of content knowledge and cognitive process. Because the scale was derived empirically rather than from a specific model of cognition, increasing levels on the scale represent increasingly complex content and cognitive processes as demonstrated through performance. The scale does not, however, simply extend from simple content at the bottom to reasoning and analyzing at the top.

The cognitive processes of knowing and of reasoning and analyzing can be seen across all levels of the scale, depending on the issues to which they apply. The scale includes a synthesis of the common elements of civic and citizenship content at each level and the typical ways in which students use that content. Each level of the scale references the degree to which students appreciate the interconnectedness of civic systems, as well as 
the sense students have of the impact of civic participation on their communities. The scale broadly reflects development encompassing the concrete, familiar, and mechanistic elements of civics and citizenship through to the wider policy and institutional processes that determine the shape of our civic communities, with the following three levels (see Appendix B for a more detailed description):

1. Level 1 of the scale is characterized by students' engagement with the fundamental principles and broad concepts that underpin civics and citizenship. Students operating at this level are familiar with the "big ideas" of civics and citizenship; they are generally able to accurately determine what is fair or unfair in familiar contexts and to demonstrate some knowledge of the most basic operations of civic and civil institutions. Students working at Level 1 also typically demonstrate awareness of citizens' capacity to influence their own local context. The key factors that differentiate Level 1 achievement from that of higher levels relate to the degree of specificity of students' knowledge and the amount of mechanistic rather than relational thinking that students express in regard to the operations of civic and civil institutions.

2. Students working at Level 2 typically demonstrate some specific knowledge and understanding of the most pervasive civic and citizenship institutions, systems, and concepts. These students generally understand the interconnectedness of civic and civil institutions, and the processes and systems through which they operate (rather than only being able to identify their most obvious characteristics). Level 2 students are also able to demonstrate understanding of the connection between principles or key ideas and how these operate in policy or practice in everyday, familiar contexts. They can relate some formal civic processes to their everyday experience and are aware that the potential sphere of influence (and, by inference, responsibility) of active citizens lies beyond their own local context. One key factor differentiating Level 2 from Level 3 is the degree to which students use knowledge and understanding to evaluate and justify policies and practices.

3. Students working at Level 3 demonstrate a holistic rather than a segmented knowledge and understanding of civic and citizenship concepts. They make evaluative judgments about the merits of policies and behaviors from given perspectives, justify positions or propositions, and hypothesize outcomes based on their understanding of civic and citizenship systems and practices. Students working at Level 3 demonstrate understanding of active citizenship practice as a means to an end rather than as an "automatic response" expected in a given context. These students are thus able to evaluate active citizenship behaviors in light of their desired outcomes.

\subsection{Questionnaire scales}

ICCS reports on outcomes of civic and citizenship education and contexts based on a number of scales derived from the international and regional student questionnaire and the teacher and school questionnaires. Typically, items will be scaled using the IRT Rasch partial credit model (see Schulz, \& Friedman, 2011).

The (international) student questionnaire includes items that will be used to obtain the following indices or sets of indices ${ }^{14}$ related to affective-behavioral and contextual factors:

14 The numbers of items measuring each index or set of indices (in brackets) do not include (individual) optional items and some may include items which could be discarded from scaling when deriving the final indices depending on the outcomes of main survey data analyses. 


\section{Attitudes}

- Students' perceptions of good citizenship (17 items, three dimensions expected)

- Students' trust in institutions (12 items)

- Students' perceptions of threats to the world's future (13 items)

- Students' attitudes towards democratic values (9 items)

- Students' attitudes toward gender rights (7 items)

- Students' attitudes toward equal rights for all ethnic/racial groups (5 items)

- Students' valuing of student participation at school (5 items)

- Students' attitudes toward their country of residence (5 items)

- Students' attitudes toward the influence of religion in society (international option, 6 items)

\section{Engagement}

- Students' sense of citizenship self-efficacy (7 items)

- Students' expectations to participate in civic action in support of or protest against important issues (11 items, two dimensions expected)

- Students' expectations of participation as adults (10 items, three dimensions expected)

- Students' expectations of future school participation (5 items

- Students' engagement with social media (3 items)

- Students' (past or present) involvement in organizations and groups outside of school (7 items)

- Students' (past or present) involvement in school activities (6 items)

\section{Context}

- Students' perceptions of open classroom climates for discussion of political and social issues (6 items)

- Students' reports on civic learning at school (7 items)

- Students' perceptions of teacher-student relationships at school (6 items)

- Students' perceptions of social interaction between students at school (4 items)

- Students' reports on verbal and physical abuse (bullying) at school (6 items)

- Students' reports of discussions about political and social issues with parents and peers (4 items)

The European regional student questionnaire includes items that will be used to obtain the following indices:

- Students' perceptions of future of Europe (8 items)

- Students' attitudes toward cooperation between European countries (8 items)

- Students' attitudes toward the European Union (5 items)

- Students' perceptions of discrimination in European societies (7 items)

- Students' views on age limitations for young people (11 items)

- Students' attitudes toward political and ethical consumerism (6 items)

- Students' sense of European identity (4 items)

- Students' perceptions of their own individual future (5 items)

- Students' attitudes towards immigration (5 items) 
- Students' views on freedom of European citizens to reside and work within Europe (6 items)

- Students' reports on opportunities to learn about Europe at school (4 items)

The Latin American regional student questionnaire includes items that will be used to obtain the following indices:

- Students' attitudes toward authoritarian government practices (11 items)

- Students' perception of discrimination of minorities in Latin American societies (9 items)

- Students' attitudes toward disobedience to the law (10 items)

- Students' sense of empathy (11 items)

- Students' attitudes toward homosexuality (5 items)

- Students' attitudes toward corrupt practices (6 items)

- Students' attitudes toward violence (10 items, two dimensions expected)

- Students' acceptance of diversity (8 items)

The teacher questionnaire includes items to derive the following contextual indices:

- Teachers' participation in school governance (5 items)

- Teachers' perceptions of social problems at school (9 items)

- Teachers' perceptions of student activities in the community (9 items)

- Teachers' perceptions of student behavior at school (6 items)

- Teachers' perceptions of classroom climate (4 items)

- Teachers' perceptions of bullying at school (8 items)

- Teachers' reports on activities related to environmental sustainability (7 items)

- Teachers' reports on class activities related to civic and citizenship education (international option, 8 items)

- Teachers' preparation for teaching related to civic and citizenship education (international option, 11 items)

- Teachers' reports on their training in topics related to to civic and citizenship education (international option, 11 items)

- Teachers' reports on their training in teaching methods (international option, 5 items)

The school questionnaire includes items to derive the following contextual indices:

- Principals' perceptions of teacher participation in school governance (5 items)

- Principals' perceptions of student sense of belonging to the school (4 items)

- Principals' perception of teacher sense of belonging to the school (4 items)

- Principals perceptions of student opportunities to participate in community activities (9 items)

- Principals' perception of bullying at school (6 items)

- Principals' reports on activities to prevent bullying at school (8 items)

- Principals perceptions of the engagement of the school community (6 items)

- Principals' reports on activities related to environmental sustainability (5 items)

- Availability of resources in local community (10 items)

- Principals perceptions of social tension in the community (12 items)

- Principals' perceptions of school autonomy in CCE delivery (8 items) 
Open Access This chapter is distributed under the terms of the Creative Commons AttributionNonCommercial 4.0 International License (http://creativecommons.org/licenses/by-nc/4.0/), which permits any noncommercial use, duplication, adaptation, distribution and reproduction in any medium or format, as long as you give appropriate credit to the original author(s) and the source, provide a link to the Creative Commons license and indicate if changes were made.

The images or other third party material in this chapter are included in the works Creative Commons license, unless indicated otherwise in the credit line; if such material is not included in the works Creative Commons license and the respective action is not permitted by statutory regulation, users will need to obtain permission from the license holder to duplicate, adapt or reproduce the material. 


\section{References}

AERA (2013). Prevention of bullying in schools, colleges, and universities: Research report and recommendations. Washington, DC, USA: American Educational Research Association.

Ainley, J., Schulz, W., \& Friedman, T. (Eds.) (2013). ICCS 2009 Encyclopedia. Approaches to civic and citizenship education around the world. Amsterdam, The Netherlands: International Association for the Evaluation of Educational Achievement (IEA).

Ajzen, I. (2001). Nature and operation of attitudes. Annual Review of Psychology, 52, 27-58.

Ajzen, I. \& Fishbein, M. (2000). Attitudes and the attitude-behavior relation: Reasoned and automatic processes. European Review of Social Psychology, 11(1), 1-33.

Almgren, E. (2006). Att fostra demokrater: Om skolan i demokratin och demokratin i skolan (To educate democracy: on democracy in school or school in democracy). Dissertation. Uppsala, Sweden: University of Uppsala. Available from http://www.skolporten.se/forskning/avhandling/ att-fostra-demokrater-om-skolan-i-demokratin-och-demokratin-i-skolan/.

Alnæs, K. (2013). Roots of European identity. Challenges and threats. Debates on European identity (2013-2014). Strasbourg, France: Council of Europe. Retrieved from http://www.coe.int/t/policyplanning/Debates/Identity_Debates/Speech_Alnaes_en.pdf.

Alsos, K., \& Eldring L. (2008). Labour mobility and wage dumping: the case of Norway. European Journal of Industrial Relations, 14(4), 441-459.

Althof, W., \& Berkowitz, M. (2006). Moral education and character education: their relationship and roles in citizenship education. Journal of Moral Education, 35(4), 495-518.

Amadeo, J., Torney-Purta, J., Lehmann, R., Husfeldt, V., \& Nikolova, R. (2002). Civic knowledge and engagement: An IEA study of upper secondary students in sixteen countries. Amsterdam, The Netherlands: International Association for the Evaluation of Educational Achievement (IEA).

Amnå, E., \& Ekman, J. (2014). Standby citizens: diverse faces of political passivity. European Political Science Review, 6, 261-281

Amnå, E., Ekström, M., Kerr, M., \& Stattin, H. (2009). Political socialization and human agency. The development of civic engagement from adolescence to adulthood. Statsvetenskaplig Tidskrift, 111(1), 27-40.

Anderson, J. R., Greeno, J. G., Reder, L. M., \& Simon, H. A. (2000). Perspectives on learning, thinking, and activity. Educational Researcher 29(4): 11-13.

Anderson, L. W. \& Krathwohl, D. A. (2001). Taxonomy for learning, teaching and assessing: A Revision of Bloom's taxonomy of educational objectives. New York, NY, USA: Longman.

Anderson, L. W., Ryan, D. W., \& Shapiro, B. J. (Eds.). (1989). The IEA classroom environment study. Oxford, UK/New York, NY, USA: Pergamon Press.

Anduiza, E., Jensen, M. J., \& Jorba, L. (Eds.) (2012). Digital media and political engagement worldwide: A comparative study. New York, NY, USA: Cambridge University Press.

Annette, J. (2000). Education for citizenship, civic participation and experiential service learning in the community. In R. Gardner et al. (Eds.), Education for Citizenship. London, UK: Continuum.

Annette, J. (2008). Community involvement, civic engagement and service learning. In J. Arthur, I. Davies, \& C. Hahn (Eds.), The SAGE handbook of education for citizenship and democracy (pp. 388-397). London, UK: SAGE Publications.

Atria, M., Strohmeier, D., \& Spiel, C. (2007). The relevance of the school class as social unit for the prevalence of bullying and victimization. European Journal of Developmental Psychology, 4(4), 372-387.

Bachen, C., Raphael, C., Lynn, K., McKee, C., \& Philippi, J. (2008). Civic engagement, pedagogy, and information technology on web sites for youth. Political Communication, 25(3), 290-310. 
Bäckman, E., \& Trafford, B. (2007). Democratic governance of schools. Strasbourg, France: Council of Europe Publishing.

Baker, D., \& LeTendre, G. (2005). National differences, global similarities: World culture and the future of schooling. Stanford, CA, USA: Stanford University Press.

Banaji, S., \& Buckingham, D. (2013). The civic web: Young people, the Internet, and civic participation. Cambridge, MA, USA: MIT Press.

Bandura, A. (1986). Social foundations of thought and action: A social cognitive theory. Englewood Cliffs, NJ, USA: Prentice-Hall.

Bandura, A. (1993). Perceived self-efficacy in cognitive development and functioning. Educational Psychologist, 28(2), 117-148.

Bandura, A. (1997). Self-efficacy: The exercise of control. New York, NY, USA: W. H. Freeman and Company.

Barber, C., Fennelly, K., \& Torney-Purta, J. (2013) Nationalism and support for immigrants' rights among adolescents in 25 countries, Applied Developmental Science, 17(2), 60-75.

Barnes, S. H., \& Kaase, M. (Eds.). (1979). Political action: Mass participation in five Western democracies. Beverly Hills, CA, USA: SAGE Publications.

Bayar, Y., \& Uçanok, Z. (2012). School social climate and generalized peer perception in traditional and cyberbullying status. Educational Sciences: Theory and Practice, 12(4), 2352-2358.

Bear, G., Yang, C., Pell, M., \& Gaskins, C. (2014). Validation of a brief measure of teachers' perceptions of school climate: Relations to student achievement and suspensions. Learning Environments Research, 17(3), 339-354.

Benavot, A., Cha, Y., Kamens, D., Meyer, J., \& Wong, S. (1991). Knowledge for the masses: World models and national curricula, 1920-1986. American Sociological Review, 56, 85-100.

Bengston, V. L., Biblarz, T. J., \& Roberts, R. L. (2002), How families still matter. A longitudinal study of youth in two generations. Cambridge, UK: Cambridge University Press.

Berkowitz, W., Althof, W., \& Jones, S. (2008). Educating for civic character. In J. Arthur, I. Davies, \& C. Hahn (Eds.) SAGE Handbook of Education for Citizenship and Democracy. London, UK: SAGE Publications.

Birzea, C., Kerr, D., Mikkelsen, R., Pol, M., Froumin, I., Losito, B., \& Sardoc, M. (2004). All-European study on education for democratic citizenship policies. Strasbourg, France: Council of Europe.

Bogler, R., \& Somech, A. (2005). Organizational citizenship behavior in school: How does it relate to participation in decision-making? Journal of Educational Administration, 43(5), 420-438.

Bongardt, A., \& Torres, F. (2012). The Lisbon Strategy. In E. Jones, A. Menon, \& S. Weatherill (Eds.), The Handbook on the European Union (pp. 469-483). Oxford, UK: Oxford University Press.

Bourdieu, P. (1986). The forms of capital. In J. G. Richardson (Ed.), Handbook of theory and research for the sociology and education (pp. 241-248). New York, NY, USA: Greenwood Press.

Brese, F., \& Mirazchiyski, P. (2013). Measuring students' family background in large-scale education studies. IERI Monograph Series. Issues and Methodologies in Large-Scale Assessments 2 (Special issue), 21-47.

Brodie, J. (2004) Introduction: globalization and citizenship beyond the national state. Citizenship Studies, 8(4), 323-332.

Bronfenbrenner, U. (2004). Making human beings human: Bioecological perspectives on human development. Washington, DC, USA: SAGE Publications

Bryk, A., Sebring, P., Allensworth, E., Easton, J., \& Leppescu, S. (2010). Organizing schools for improvement. New York, NY, USA: Russell Sage Foundation Publications. 
Buchmann, C. (2002). Measuring family background in international studies of education: Conceptual issues and methodological challenges. In A. C. Porter, \& A. Gamoran (Eds.), Methodological advances in cross-national surveys of educational achievement (pp. 150-197). Washington, DC, USA: National Academy Press.

Burnouf, L. (2004). Global awareness and perspectives in global education. Canadian Social Studies, 38(3). Retrieved from http://www.educ.ualberta.ca/css/Css_38_3/ARburnouf_global_ awareness_perspectives.htm.

Cabrera, A.F., Nora, A., Terenzini, P.T., Pascarella, E., \& Hagedorn, L.S. (1999) Campus racial climate and the adjustment of students to college. The Journal of Higher Education, 70(2), 134-160.

Canache, D., Hayes, M., Mondak, J. J., \& Seligson, M. A. (2014). Determinants of perceived skincolor discrimination in Latin America. Journal of Politics, 76, 506-520.

Caro, D. H., \& Cortés, D. (2012). Measuring family socioeconomic status: an illustration using data from PIRLS 2006. IERI Monograph Series. Issues and Methodologies in Large-Scale Assessments, 5, 9-33.

Caro, D. H., \& Schulz, W (2012). Ten hypotheses about tolerance among Latin American adolescents. Citizenship, Social and Economics Education, 11(3), 213-234.

Carrera, S. (2005). What does free movement mean in theory and practice in an enlarged EU? European Law Journal, 11(6), 699-721.

Chaux, E. (2009). Citizenship competencies in the midst of a violent political conflict: The Colombian educational response. Harvard Educational Review, 79, 84-93.

Chaux, E., Lleras, J., \& Velásquez, A. M. (2004). Competencias ciudadanas: de los estándares al aula. Una propuesta de integración a las áreas académicas [Citizenship competencies: From the standards into the classroom. A proposal for integrating learning areas]. Bogotá, Colombia: Ceso, Ediciones Uniandes, Ministry of Education.

Chaux, E., \& Velásquez, A. M. (2009). Peace education in Colombia: The promise of citizenship competencies. In V. Bouvier (Ed.), Colombia: Building peace in a time of war (pp. 159-171). Washington, DC, USA: United States Institute of Peace.

Checkel, J. T., \& Katzenstein, P. J. (2009). European identity. Cambridge, UK: Cambridge University Press.

Chong, A. \& Ñopo, H. (2007). Discrimination in Latin America: An elephant in the room? Research Department Working Paper 614. Washington, DC, USA: Inter-American Development Bank.

Chossudovsky, M., \& Marshall, A. (2010). The global economic crisis: The great depression of the XXI century. Montreal, Canada: Global Research Publishers. Centre for Research on Globalization (CRG).

Citizenship Foundation. (2013). Economic awareness. London, UK: Citizenship Foundation. Retrieved from: http://www.citizenshipfoundation.org.uk/main/page.php?353.

Coleman, J. S. (1988). Social capital in the creation of human capital. American Journal of Sociology, 94(supplement), 95-120.

Copeland-Linder, N., Johnson, S.B., Haynie, D.L., Chung, S.E., \& Cheng, T.L. (2012). Retaliatory attitudes and violent behaviours among assault-injured youth, Journal of Adolescent Health, 50(3), 215-220.

Côté, R.R., \& Erickson, B.H. (2009) Untangling the roots of tolerance: How forms of social capital shape attitudes toward ethnic minorities and immigrants. American Behavioral Scientist, 52(12), $1664-1689$.

Council of Europe. (2007). Democratic governance of schools. Strasbourg, France: Author.

Corcoran, L., \& Mc Guckin, C. (2014). Addressing bullying problems in Irish schools and in cyberspace: A challenge for school management, Educational Research, 56(1), 48-64. 
Cox, C. (2010). Informe de Referente Regional 2010: Oportunidades de aprendizaje escolar de la ciudadanía en América Latina: currículos comparados [Report on regional references 2010: opportunities for learning about citizenship in Latin America. A comparison of curricula]. Bogotá, Colombia: Regional System for the Development and Evaluation of Citizenship Comptencies.

Cox, C., Jaramillo, R., \& Reimers, F. (2005). Education for citizenship and democracy in the Americas: An agenda for action. Washington, DC, USA: Inter-American Development Bank.

Dalton, R. (2002). The decline of party identifications. In R. Dalton \& M. Wattenberg (Eds.), Parties without partisans (pp. 19-36). Oxford, UK: Oxford University Press.

Davies, P. (2006). Educating citizens for changing economies. Journal of Curriculum Studies, 38(1), $15-30$.

Davies, P. (2015). Towards a framework for financial literacy in the context of democracy. Journal of Curriculum Studies, 47(2), 300-316.

Davies, P., Howie, H., Mangan, J., \& Telhaj, S. (2002). Economic aspects of citizenship education: An investigation of students' understanding. The Curriculum Journal, 13(2), 201-223.

Delanty, G. (1995). Inventing Europe: Idea, identity, reality. London, UK: Palgrave Macmillan.

Delanty, G. (2006). The cosmopolitan imagination: critical cosmopolitanism and social theory. The British Journal of Sociology, 57(1), 25-47.

Delanty, G. (2007). European citizenship: A critical assessment. Citizenship Studies, 11(3), 64-72.

Delanty, G., \& Rumford, C. (2005). Rethinking Europe. Social theory and the implications of Europeanization. London, UK: Routledge

Diamond, L. (2015). Facing up to democratic recession. Journal of Democracy, 26(1), 141-155.

Dijkstra, A.B., \& De la Motte, P.I. (Eds.) (2014). Social outcomes of education. The assessment of social outcomes and school improvement through school inspections. Amsterdam, The Netherlands: Amsterdam University Press.

Dobson, A. (2003). Citizenship and the environment. Oxford, UK: Oxford University Press.

Dobson, A. \& Bell, D. (Eds.) (2006). Environmental citizenship. Cambridge, MA, USA: MIT Press.

Dølvik, J. E. \& Eldring L. (2008). Mobility of labour from the new EU states to the Nordic region: Trends and consequences. TemaNord 2008:537. Copenhagen, Denmark: Nordic Council of Ministers. Retrieved from http://www.diva-portal.org/smash/get/diva2:702309/FULLTEXT01.pdf.

Dringer, E. (2013). A patchwork of emissions cuts. Nature, 501, 307-309.

Duchesne, S. (2008). Waiting for a European identity. Reflections on the process of identification with Europe. Perspectives on European Politics and Society, 9(4), 397-410.

Durlak, J. A., Weissberg, R. P., Dymnicki, A. B., Taylor, R. D., \& Schellinger, K. B. (2011). The impact of enhancing students' social and emotional learning: A meta-analysis of school-based universal interventions. Child Development, 82(1), 405-432.

Eckstein, K., Noack, P., \& Gniewosz, B. (2013). Predictors of intentions to participate in politics and actual political behaviors in young adulthood. International Journal of Behavioral Development, 37(5), 428-435.

Edmonds, R. R. (1979). Effective schools for the urban poors. Educational Leadership, 37(10), $15-24$.

Ehman, L. H. (1980). Change in high school pupils' political attitudes as a function of social studies classroom climate. American Educational Research Journal, 17, 253-265.

Eisenberg, N. (1995). Prosocial development: A multifaceted model. In W. M. Kurtines, \& J. L.Gerwitz (Eds.), Moral development: An introduction (pp. 401-429). Needham Heights, MA, USA: Prentice Hall.

Ekman, J., \& Amnå, E. (2012). Political participation and civic engagement: Towards a new typology. Human Affairs, 22, 283-300. 
Elley, W. B. (1992). How in the world do students read? The Hague, The Netherlands: International Association for the Evaluation of Educational Achievement (IEA).

Entwistle, D. R. A., \& Astone, N. M. (1994). Some practical guidelines for measuring youth's race/ ethnicity and socioeconomic status. Child Development, 65, 1521-1540.

European Commission. (2010). EU citizens' attitudes towards alcohol. Brussels, Belgium: Author. Retrieved from http://ec.europa.eu/public_opinion/archives/ebs/ebs_331_en.pdf.

European Commission. (2012a). Special Eurobarometer 393. Discrimination in the EU in 2012. Brussels, Belgium: Author. Retrieved from http://ec.europa.eu/public_opinion/archives/ebs/ ebs_393_sum_en.pdf

European Commission. (2012b). The development of European identity/identities: Unfinished business. A policy review. Brussels, Belgium: Author. Retrieved from https://ec.europa.eu/research/ social-sciences/pdf/policy_reviews/development-of-european-identity-identities_en.pdf.

European Commission. (2013). Political participation and EU citizenship: Perceptions and behaviours of young people. Evidence from Eurobarometer surveys. Brussels, Belgium: Author. Retrieved from http://eacea.ec.europa.eu/youth/tools/documents/perception-behaviours.pdf.

European Commission. (2014). Special Eurobarometer 413. Future of Europe. Brussels, Belgium: Author. Retrieved from http://ec.europa.eu/public_opinion/archives/ebs/ebs_413_en.pdf.

European Commission. (2015). Public opinion in the European Union. First results. Brussels, Belgium: Author. Retrieved from http://ec.europa.eu/public_opinion/archives/eb/eb83/eb83 first_en.pdf.

Eurydice. (2005). Citizenship education at school in Europe. Brussels, Belgium: Author.

Eurydice. (2007). School autonomy in Europe: Policies and measures. Brussels, Belgium: Author.

Eurydice. (2012). Citizenship education in Europe. Brussels, Belgium: Author.

Eurydice. (2013). Key data on teachers and school leaders in Europe. Brussels, Belgium: Author.

Ferreira, J. (2013). Transformation, empowerment, and the governing of environmental conduct: insights to be gained from "history of the present" approach. In R. Stevenson, M. Brody, J. Dillon, \& A. Wals (Eds.), International Handbook of Research on Environmental Education (pp. 63-73). Washington, DC, USA: American Educational Research Association.

Fligstein, N. (2009). Euroclash: The EU, European identity, and the future of Europe. Oxford, UK: Oxford University Press.

Fraillon, J., Ainley, J., Schulz, W., Friedman, T., \& Gebhardt, E. (2014). Preparing for life in a digital age. The IEA International Computer and Literacy Information Study International Report. Amsterdam, The Netherlands: International Association for the Evaluation of Educational Achievement (IEA).

Fraillon, J., Schulz, W., \& Ainley, J. (2012). ICCS 2009 Asian Report. Civic knowledge and attitudes among lower secondary students in five Asian countries. Amsterdam, The Netherlands: IEA.

Fredericks, J., Blumenfeld, P., \& Paris, A. (2004). School engagement: Potential of the concept, state of the evidence. Review of Educational Research, 74(1), 59-96.

Fuligni, A. J. (1997). The academic achievement of adolescents from immigrant families: The roles of family background, attitudes, and behavior. Child Development, 68(2), 351-363.

Ganzeboom, H. B. G., de Graaf, P. M., \& Treiman, D. J. (1992). A standard international socioeconomic index of occupational status. Social Science Research, 21, 1-56.

Gerbner, G. (1980). The mainstreaming of America. Journal of Communication, 30, 10-29.

German Marshall Fund (2014). Transatlantic trends: Key findings 2014. Washington, DC, USA: Author. Retrieved from http://trends.gmfus.org/files/2012/09/Trends_2014_complete.pdf.

Ginther, D. K., \& Pollak, R.A. (2004). Family structure and children's educational outcomes: Blended families, stylized facts, and descriptive regressions. Demography, 41(4), 671-696. 
Goldsmid, S., \& Howie, P. (2014). Bullying by definition: An examination of definitional components of bullying. Emotional and Behavioural Difficulties, 19(2): 210-225.

Gottfried, A. W. (1985). Measures of socioeconomic status in child development research: Data and recommendations. Merrill-Palmer Quarterly, 31(1), 85-92.

Gould, J. (Ed.). (2011). Guardian of democracy: The civic mission of schools. Washington, DC, USA: National Conference on Citizenship. Retrieved from http://www.ncoc.net/guardianofdemocracy.

Grant, W., \& Wilson, K. (Eds) (2012). The Consequences of the Global Financial Crisis: The Rhetoric of Reform and Regulation. Oxford, UK: Oxford University Press.

Grusec, J. E., \& Kuczynski, L. (Eds.). (1997). Parenting and children's internalization of values: A handbook of contemporary theory. New York, NY, USA: John Wiley.

Guo, C., Webb, N. J., Abzuq, R., \& Peck, L. R. A. (2013). Religious affiliation, religious attendance, and participation in social change organizations. Nonprofit and Voluntary Sector Quarterly, 42(1), $34-58$.

Hahn, L. (1999). Citizenship education: An empirical study of policy, practices and outcome. Oxford Review of Education, 25, 231-250.

Halstead, M., \& Pike, M. (2006). Citizenship and moral education: Values in action. London, UK: Routledge.

Hambleton, R. K., Swaminathan, H., \& Rogers, H. J. (1991). Fundamentals of item response theory. Newbury Park, CA, UK/London, UK/New Delhi, India: SAGE Publications.

Hanushek, E. A. (1994). Money might matter somewhere: A response to Hedges, Laine, \& Greenwald. Educational Researcher, 23, 5-8.

Hanushek, E. A. (1997). Assessing the effects of school resources on student performance: An update. Educational Evaluation and Policy Analysis, 19, 141-164.

Hanushek, E.A. (2006). School Resources. In E.A Hanushek, \& F. Welch (Eds.), Handbook of the Economics of Education, Volume 2 (pp. 865-908). Amsterdam, The Netherlands: Elsevier B.V.

Harvey-Beavis, A. (2002). Student and school questionnaire development. In R. Adams, \& M. Wu (Eds.), PISA 2000 technical report (pp. 33-38). Paris, France: OECD Publications.

Hauser, R. M. (1994). Measuring socioeconomic status in studies of child development. Child Development, 65, 1541-1545.

Hayward, T. (2006). Ecological citizenship: Justice, rights and the virtue of resourcefulness. Environmental Politics, 15(3), 435-446.

Henderson, A., Pancer, S. M., \& Brown, S. D. (2013) Creating effective civic engagement policy for adolescents: Quantitative and qualitative evaluations of compulsory community service. Journal of Adolescent Research, 29(1), 120-154.

Henderson, K., \& Tilbury, D. (2004). Whole school approaches to sustainability: An international review of sustainable school programs. Sidney, Australia: ARIES.

Herrmann, R. K., Risse, T., \& Brewer, B. M. (Eds.) (2004). Transnational identities: Becoming European in the EU. Lanham, MD, USA: Rowman E Littlefield Publishers Inc.

Hess, R. D., \& Torney, J. (1967). The development of political attitudes in children. Garden City, NY, USA: Anchor.

Hicks, D. (2003). Thirty years of global education: a reminder of key principles and precedents. Educational Review, 55(3), 265-275.

Hoffman, M. L. (1981). The development of empathy. In J. P. Rushton \& R. M. Sorrentino (Eds.), Altruism and helping behavior (pp. 41-63). Lincoln, NE: University of Nebraska Press.

Holden, C. (2007). Young people's concerns. In D. Hicks, \& C. Holden (Eds.), Teaching the global dimension: Key principles and effective practice (pp. 31-42), London, UK: Routledge Falmer. 
Homana, G., Barber, C., \& Torney-Purta, J. (2006). Assessing school citizenship education climate: Implications for the social studies (Circle Working Paper 48). Retrieved from http://civicyouth.org/ circle-working-paper-48-assessing-school-citizenship-education-climate-implications-for-thesocial-studies/.

Hooghe, M., \& Quintelier, E. (2013). The relationship between political participation intentions of adolescents and a participatory democratic climate at school in 35 countries. Oxford Review of Education, 39(5), 567-589.

Huckle, J. (2008). Sustainable development. In J. Arthur, I. Davies, \& C. Hahn (Eds.), The Sage Handbook of Education for Citizenship and Democracy (pp. 342-354). London, UK: SAGE Publications.

Huddleston, T. (2007). From student voice to shared responsibility: Effective practice in democratic school governance in European schools. London, UK: Citizenship Foundation.

Huddy, L., \& Khatib, N. (2007). American patriotism, national identity, and political involvement. American Political Science Review, 51(1), 63-77.

Husman, J., \& Shell, D. (2008). Beliefs and perceptions about the future: A measurement of future time perspective. Learning and Individual Differences, 18(2), 166-175.

IPCC. (2014). Climate Change 2014: Mitigation of Climate Change. Contribution of Working Group III to the Fifth Assessment Report of the Intergovernmental Panel on Climate Change. O. Edenhofer, R. Pichs-Madruga, Y. Sokona, E. Farahani, S. Kadner, K. Seyboth, A. Adler, I. Baum, S. Brunner, P. Eickemeier, B. Kriemann, J. Savolainen, S. Schlömer, C. von Stechow, T. Zwickel, \& J.C. Minx (Eds.). Cambridge, United Kingdom and New York, NY, USA: Cambridge University Press.

International Labour Organisation. (1990). International Standard Classification of Occupations: ISCO-88. Geneva, Switzerland: International Labour Office.

Istrate, O., Noveanu, G., \& Smith, T. M. (2006). Exploring sources of variation in Romanian science achievement. Prospects: Quarterly Review of Comparative Education, 36(4), 475-496.

Ishimaru, A. (2013). From heroes to organizers: Principals and education organizing in urban school reform. Educational Administration Quarterly, 49(1) 3-51.

Janoski, J., \& Wilson, J. (1995). Pathways to voluntarism: Family socialization and status transmission models, Social Forces, 74(1), 271-292.

Jennings, M. K., Stoker, L., \& Bowers, J. (2001). Politics across the generations: Family transmission reexamined (working paper 2001-15). Berkeley, CA, USA: Institute of Governmental Studies.

Johnson, D. W., \& Johnson, R. T. (1996) Conflict resolution and peer mediation programs in elementary and secondary schools: A review of the research. Review of Educational Research, 66 (4), 459-506.

Kaase, M. (1990). Mass participation. In M. K. Jennings, J. W. van Deth et al. (Eds.), Continuities in Political Action (pp. 23-67). Berlin, Germany/New York, NY, USA: Walter de Gruyter.

Kagan, R. (2015). The weight of geopolitics. Journal of Democracy, 26(1), 21-31.

Kahne, J., Lee, N., \& Feezell, J. T. (2011). The civic and political significance of online participatory cultures among youth transitioning to adulthood. Retrieved from: http://dmlcentral.net/sites/ dmlcentral/files/resource_files/OnlineParticipatoryCultures.WORKINGPAPERS.pdf.

Kahne, J., Middaugh, E., \& Allen, D. (2014). Youth, new media and the rise of participatory politics. YPP Research Network Working Paper \#1. Oakland, CA, USA: Youth and Participatory Politics Research Network.

Kärnä, A., Voeten, M., Little, T. D., Poskiparta, E., Kaljonen, A., \& Salmivalli, C. (2011). A largescale evaluation of the KiVa antibullying program: Grades 4-6. Child Development, 82, 311-330.

Kao, G. (2001). Race and ethnic differences in peer influences on educational achievement. In D. Massey, \& E. Anderson (Eds.), The problem of the century: Racial stratification in the US at the millennium (pp. 437-460). New York, NY, USA: Russell Sage. 
Karolewski, I. P., \& Kaina, V. (2006). European identity. Theoretical perspectives and empirical insights. Berlin, Germany: LIT Verlag.

Karolewski, I. P., \& Kaina, V. (2013). EU governance and European identity. Living Reviews in European Governance, 8(1), 5-59. Retrieved from http://www.livingreviews.org/lreg-2013-1.

Keating, A., \& Janmaat, J. G. (2015). Education through citizenship at school: Do school activities have a lasting impact on youth political engagement? Parliamentary Affairs, gsv017. Retrieved from http://pa.oxfordjournals.org/content/early/2015/05/24/pa.gsv017.full.

Keating, A., \& Kerr,D. (2013). Putting participation into practice. Re-evaluating the implementation of the Citizenship curriculum in England. In R. Hedtke, \& T. Zimenkova (Eds.), Education for civic and political participation. A critical approach (pp. 117-132). New York, NY, USA: Routledge.

Keating, A., Kerr, D., Benton, T., Mundy, E., \& Lopes, J. (2010). Citizenship education in England 2001-2010: Young peoples' practices and prospects for the future, the eighth and final report from the Citizenship Education Longitudinal Study (CELS). London, UK: DfE.

Kelley, J. (2001). Attitudes towards homosexuality in 29 nations. Australian Social Monitoring, 4, 15-22.

Kennedy, K. (2006). Towards a conceptual framework for understanding active and passive citizenship. Unpublished report. Retrieved from http://www.academia.edu/1243639/ towards_a_conceptual_ framework_for_active_citizenship.

Kennedy, K. (2010). Young citizens in Hong Kong: Obedient, active and patriotic. Social Psychology of Education, 13(1), 111-127.

Kennedy, K. (2012). Global trends in civic and citizenship education: What are the lessons for nation states? Education Sciences, 2, 121-135. doi:10.3390/educsci2030121.

Kerr, D., Ireland, E., Lopes, J., \& Craig, R., with Cleaver, E. (2004). Making citizenship real: Citizenship Education Longitudinal Study. Second annual report. First longitudinal survey (DfES Research Report 531). London, UK: Department for Education and Skills (DfES).

Kerr, D., Schulz, W., Fraillon, J. (2011). The development of regional instruments. In W. Schulz, J. Ainley, \& J. Fraillon (Eds.), ICCS 2009 technical report (pp. 45-49). Amsterdam, The Netherlands: International Association for the Evaluation of Educational Achievement (IEA).

Kerr, D., Sturman, L., Schulz, W., \& Burge, B. (2010). ICCS 2009 European Report. Civic knowledge, attitudes and engagement among lower secondary school students in twenty-four European countries. Amsterdam, The Netherlands: International Association for the Evaluation of Educational Achievement (IEA).

Khoo, S. K., \& Ainley, J. (2005). Attitudes, intentions and participation. LSAY Report No. 45. Melbourne, Australia: ACER.

Knowles, R.T., \& McCafferty-Wright, J. (2015). Connecting an open classroom climate to social movement citizenship: A study of 8th graders in Europe using IEA ICCS data. The Journal of Social Studies Research, 39(4), 255-269.

Kyburz-Graber, R. (2013). Socioecological approaches to environmental education and research. A paradigmatic response to behavioral change orientations. In: R. B. Stevenson et al. (Eds.), International handbook of research on environmental education (pp. 23-32). New York, NY, USA, \& London, UK: AERA-Routledge.

L'Homme, C., \& Jerez Henríquez, C. (2010). Education, youth and development. UNESCO in Latin America and the Caribbean. Santiago, Chile: UNESCO. Retrieved from http://www.unesco.org/ santiago.

Lamont, M., \& Lareau, A. (1988). Cultural capital: allusions, gaps and glissandos in recent theoretical developments. Sociological Theory, 6, 153-168.

Latinobarometro (2009). Informe 2009. Santiago, Chile: Corporación Latinobarómetro. Retrieved from http://www.latinobarometro.org/documentos/latbd_latinobarometro_informe_2009.pdf. 
Lauglo, J. (2011). Political socialization in the home and young people's educational achievement and ambition. British Journal of Sociology of Education, 32(1), 53-74.

Lauglo, J. (2013). Do more knowledgeable adolescents have more rationally based civic attitudes? Analysis of 38 countries. Educational Psychology, 33(3), 262-282.

Lauglo, J., \& Øia, T. (2006). Education and civic engagement among Norwegian youths (NOVA report 14/06). Oslo, Norway: Norwegian Social Research.

Lehmann, R. (1996). Reading literacy among immigrant students in the United States and former West Germany. In M. Binkley, K. Rust, \& T. Williams (Eds.), Reading literacy in an international perspective (pp. 101-114). Washington, DC, USA: National Center for Education Statistics (NCES).

Lemola, S., Raikkonen, K., Mathews, K., Scheier, M., Heinonen, K., Pesonen, A., \& Lahti, J. (2010). A new measure for dispositional optimism in young children. European Journal of Personality, 24(1), 71-84.

Letki, N. (2006). Investigating the roots of civic morality: Trust, social capital, and institutional performance. Political Behavior, 28(4), 305-325.

Losito, B., \& Mintrop, H. (2001). The teaching of civic education. In J. Torney-Purta, R. Lehmann, H. Oswald, \& W. Schulz (Eds.), Citizenship and education in twenty-eight countries (pp. 157173). Amsterdam, The Netherlands: International Association for the Evaluation of Educational Achievement (IEA).

Lotz-Sisitka, H., Fien, J., \& Ketlhoilwe, M. (2013). Traditions and new niches: An overview of environmental education curriculum and learning research. In R. Stevenson, M. Brody, J. Dillon, \& A. Wals (Eds.), International handbook of research on environmental education (pp. 194-205). Washington, DC, USA: American Educational Research Association.

Lundholm, C., Hopwood, N., \& Kelsey, E. (2013). Environmental learning: Insights from research Into the student experience. In: R. B. Stevenson et al. (Eds.), International handbook of research on environmental education (pp. 243-252). New York, NY, USA and London, UK: AERA-Routledge.

Marjoribanks, K. (1997). Children of single-parent families. In L. J. Saha (Ed.), International Encyclopedia of the Sociology of Education (pp. 589-595). Oxford, UK/New York, NY, USA/Tokyo, Japan: Elsevier.

Marzano, R. J. (2003). What works in schools. Translating research into action. Alexandria, Egypt: ASCD.

Masso, A. (2009). A readiness to accept immigrants in Europe? Individual and country-level characteristics. Journal of Ethnic and Migration Studies, 35(2), 251-270.

McLanahan, S. S., \& Sandefur, G. D. (1994). Growing up with a single parent: What hurts, what helps. Cambridge, MA, USA: Harvard University Press.

Mellor, S., \& Prior, W. (2004). Citizenship education in Asia and the Pacific: Promoting social tolerance and cohesion in the Solomon Islands and Vanuatu. In W. O. Lee, D. L. Grossman, K. Kennedy, \& G. P. Fairbrother (Eds.), Citizenship education in Asia and the Pacific: Concepts and issues (pp. 175-194). Hong Kong: Comparative Education Research Centre (CERC) and Kluwer Academic Publishers.

Menezes, I., Ferreira, P. D., Carneiro, N. S., \& Cruz, J. B. (2004). Citizenship, empowerment and participation: Implications for community interventions. In A. Sánchez Vidal, A. Zambrano Constanzo, \& L. M. Palacín (Eds.), Psicologia Comunitaria Europea: Comunidad, ética y valores (European community psychology: Community, ethics and values) (pp. 301-308). Barcelona, Spain: Publicacions Universitat de Barcelona.

Merrell, K. W., Gueldner, B. A., Ross, S. W., \& Isava, D.M. (2008). How effective are school bullying intervention programs? A meta-analysis of intervention research School Psychology Quarterly, 23(1), 26-42. http://dx.doi.org/10.1037/1045-3830.23.1.26

Micheletti, M., \& Stolle D. (2015). Concept of political consumerism. In L. R. Sherrod (Ed.), Youth activisism: An international encyclopedia. Westport, CT, USA: Greenwood Publishing. 
Micheletti, M., \& Stolle, D. (Eds.). (2004). Politics, products, and markets: Exploring political consumerism past and present. Herndon, VA, USA: Transaction Publishers.

Mickelson, R. A., \& Nkomo, N. (2012). Integrated schooling, life course outcomes, and social cohesion in multiethnic democratic societies. Review of Research in Education, 36(1), 197-238.

Mihailidis, P. (2011). New civic voices and the emerging media literacy landscape. Journal of Media Literacy Education, 3(1), 4-5.

Milner, J. (2010). The internet generation: Engaged citizens or political dropouts. Medford, MA, USA: Tufts University Press.

Ministry of Education of Colombia. (2004). Estándares básicos de competencias ciudadanas. Formar para la ciudadanía ... ¡Sí es posible! Lo que necesitamos saber y saber hacer [Basic standards of citizenship ... Yes, it is possible! What we need to know and know how to do it]. Bogotá, Colombia: Author.

Morley, K. M. (2003) Fitting in by race/ethnicity: The social and academic integration of diverse students at a large predominantly white university. Journal of College Student Retention: Research, Theory and Practice, 5(2), 147-174.

Morris, S. D., \& Blake, C. H. (2010). Corruption and politics in Latin America. In S. D. Morris, \& C. H. Blake (Eds.), Corruption, and politics in Latin America (pp. 1-29). Boulder, CO, USA: Lynne Rienner.

Morris, S. D., \& Klesner, J. L. (2010). Corruption and trust: Theoretical considerations and evidence from Mexico. Comparative Political Studies, 43(10), 1258-1285.

Mosher, R., Kenny, R. A., \& Garrod, A. (1994). Preparing for citizenship: Teaching youth to live democratically. Westport, CT, USA/London, UK: Praeger.

Mullis, I. V. S., \& Martin, M. O. (Eds.). (2013). TIMSS 2015 Assessment Frameworks. Chestnut Hill, MA, USA: TIMSS, \& PIRLS International Study Center, Boston College.

Mullis, I. V. S., Martin, M. O., Gonzalez, E. J., Gregory, K. D., Garden, R. A., O’Connor, K. M., Chrostowski, S, J., \& Smith, T A. (2000). TIMSS 1999 international mathematics report: Findings from IEA's repeat of the Third International Mathematics and Science Study at the eighth grade. Chestnut Hill, MA, USA: TIMSS, \& PIRLS International Study Center, Boston College.

Mullis, I.V.S., \& Martin, M.O. Kennedy, A. M., Trong, K.L., \& Sainsbury, M. (2009). PIRLS 2011 Assessment Framework. Chestnut Hill, MA, USA: TIMSS, \& PIRLS International Study Center, Boston College.

Munn, P., Brown, J., \& Ross, H. (Eds.) (2012). Democratic citizenship in schools: Teaching controversial issues, traditions, and accountability. Edinburgh, UK: Dunedin Press.

Naval, C., Print, M., \& Veldhuis, R. (2002). Education for democratic citizenship in the new Europe: Context and reform. European Journal of Education, 37(2), 107-128.

Neal, J. W., \& Neal, Z. P. (2013). Nested or networked? Future directions for ecological systems theory. Social Development, 22(4), 722-737.

Nie, N. H., Junn, J., \& Stehlik-Barry, K. (1996). Education and democratic citizenship in America. Chicago, IL, USA: University of Chicago Press.

Niemi, R., \& Junn, J. (1998). Civic education: What makes students learn? New Haven, CT, USA: Yale University Press.

Ñopo, H., Chong, A., \& Moro, (Eds.) (2010). Discrimination in Latin America. An economic perspective. Washington, DC, USA: Inter-American Development Bank.

Norris, P. (2000). A virtuous circle: Political communication in postindustrial societies. Cambridge, UK: Cambridge University Press.

OECD. (2012). Free movement of workers and labour market adjustment. Recent experiences from OECD countries and the European Union. Paris, France: Author. 
OECD. (2005). Technical report for the OECD Programme for International Student Assessment 2003. Paris, France: OECD Publications.

OECD. (2009). Creating effective teaching and learning environments: First results from TALIS. Paris, France: Author.

OECD. (2014a). PISA 2012 results: Students and money. Financial literacy skills for the 21st century (Volume VI). Paris, France: Author.

OECD. (2014b). Talis 2013 results. An international perspective on teaching and learning. Paris, France: Author.

OECD. (2015). Skills for social progress. The power of social and emotional skills. Paris, France: Author.

Olweus, D. (1973). Hackkycklingar och översittare. Forskning om skolmobbing [Chopper chicks and bullies. Research on school bullying]. Stockholm, Sweden: Almquist, \& Wicksell.

Oscarsson, V. (1996). Pupils' views of the future in Sweden. Environmental Education Research, 2(3), 261-277.

Oser, F., \& Veugelers, W. (Eds.) (2008). Getting involved. Global citizenship and sources of moral values. Chicago, IL, USA: Sense Publishers.

Osler, A., \& Starkey, H. (2001). Citizenship education and national identities in France and England: Inclusive or exclusive? Oxford Review of Education, 27(2), 199-215.

Osler, A., \& Starkey, H. (2008). Education for cosmopolitan citizenship. In V. Georgi (Ed.), The making of citizens in Europe: New perspectives on citizenship education. Berlin, Germany: Bundeszentrale für politische Bildung (BPB) (German Federal Agency for Civic Education).

O'Sullivan, M. O., \& Pashby, K. (Eds.) (2008). Citizenship education in the era of globalization. Rotterdam, The Netherlands/Taipei, Chinese Taipei: Sense Publishers.

Paas T., \& Halapuu V. (2012). Attitudes towards immigrants and the integration of ethnically diverse societies. NORFACE Migration Discussion Paper No. 2012-23. Retrieved from http://www.norfacemigration.org/publ_uploads/NDP_23_12.pdf.

Pancer, S. M. (2015). The psychology of citizenship and civic engagement. New York, NY, USA: Oxford University Press.

Pancer, S., \& Pratt, M. (1999). Social and family determinants of community service involvement in Canadian youth. In M. Yates, \& J. Youniss (Eds.), Roots of civic identity (pp. 32-55). New York, NY, USA: Cambridge University Press.

Pasek, J., Feldman, L., Romer, D., \& Jamieson, K. (2008). Schools as incubators of democratic participation: Building long-term political efficacy with civic education. Applied Developmental Science, 12(1), 236-237.

Perks, T., \& Haan M. (2011). Youth religious involvement and adult community participation: Do levels of youth religious involvement matter? Nonprofit and Voluntary Sector Quarterly, 40(1), $107-129$.

Perliger, A., Canetti-Nisim, D., \& Pedahzur, A. (2006). Democratic attitudes among high-school pupils: The role played by perceptions of class climate. School Effectiveness and School Improvement, 17(1), 119-140.

Pew Research Center (2014). Religion in Latin America: Widespread change in a historically Catholic region. Washington, DC, USA: Author. Retrieved from http://www.pewforum.org/files/2014/11/ Religion-in-Latin-America-11-12-PM-full-PDF.pdf.

Piaget, J. (1965). The moral judgment of the child. Glencoe, IL, USA: Free Press.

Pichler, F. (2008). European identities form below: Meanings of identification with Europe. Perspectives on European Politics and Society, 9(4), 411-430.

Potter, J. (2002). Active citizenship in schools. London, UK: Kogan Page. 
Powell, J. E., Powell, A. 1., \& Petrosko, J. M. (2015). School climate as a predictor of incivility and bullying among public school employees: A multilevel analysis. Journal of School Violence, 14, 217 244.

Putnam R. D., \& Campbell D. E. (2010). American grace: How religion divides and unites us. New York, NY, USA: Simon and Schuster

Putnam, R. D. (1993). Making democracy work. Princeton, NJ, USA: Princeton University Press.

Putnam, R. D. (2000). Bowling alone: The collapse and revival of American community. New York, NY, USA: Simon and Schuster.

Rainie, L., Smith, A., Schlozman, K., Brady, H., \& Verba, S. (2012). Social media and political engagement. Washington, DC, USA: Pew Research Center’s Internet, \& American Life Project.

Ranson, S., Farrell, C., Peim, N., \& Smith, P. (2005). Does governance matter for school improvement? School Effectiveness and School Improvement, 16(3), 305-325.

Rasch, G. (1960). Studies in Mathematical Psychology: Probabilistic models for some intelligence and attainment tests, Volume 1. Copenhagen, Denmark: Danmarks Paedagogiske Institut.

Reezigt, G. J., \& Creemers, B. P. M. (2005). A comprehensive framework for effective school improvement. School Effectiveness and School Improvement, 16(4), 407-424.

Reid, A., Gill, J., \& Sears, A. (Eds.) (2010). Globalisation, the nation-state and the citizen. Dilemmas and directions for civics and citizenship education. New York, NY, USA: Routledge.

Reimers, F. (2007). Civic education when democracy is in flux: The impact of empirical research on policy and practice in Latin America. Citizenship and Teacher Education, 3(2), 5-21.

Renshon, S. A. (1975). The role of personality development in political socialization. In D. C. Schwartz, \& S. Schwartz (Eds.), New Directions in Socialization (pp. 29-68). New York, NY, USA: Free Press.

Richardson, W. (2003). Connecting political discussion to civic engagement: The role of civic knowledge, efficacy and context for adolescents. Unpublished doctoral dissertation, University of Maryland, College Park, MD, USA.

Rigby, K., \& Smith, P. K. (2011). Is school bullying really on the rise? Social Psychology of Education, 14(4), 441-455.

Robinson, M. J. (1976). Public affairs television and the growth of political malaise: The case of "the selling of the Pentagon." American Political Science Review, 70, 409-432.

Rogers, C. R. (1975). Empathic: An unappreciated way of being. Counseling Psychologist, 5, 2-10.

Rokeach, M. (1973). The nature of human values. New York, NY, USA: The Free Press.

Roland, E., \& Galloway, D. (2002). Classroom influences on bullying. Educational Research, 44(3), 299-312.

Rubin, A. (2002). Reflections upon the late-modern transition as seen in the images of the future held by young Finns, in G. Gidley, \& S. Inayatullah (Eds) Youth futures: comparative research and transformative visions (pp. 99-109), Westport, CT, USA: Praeger.

Rustenbach , E. (2010). Sources of negative attitudes toward immigrants in Europe: A multi-level analysis. International Migration Review, 44(1), 53-77.

Salmivalli, C. (2012). KiVa antibullying program: Overview of evaluation studies based on a randomized controlled trial and national rollout in Finland. International Journal of Conflict and Violence, 6(2), 294-302.

Sammons, P., Gu, Q., Day, C., \& Ko, J. (2011). Exploring the impact of school leadership on pupil outcomes: Results from a study of academically improved and effective schools in England. International Journal of Educational Management, 25(1) 83-101.

Schattle, H. (2012). Globalization and citizenship. Plymouth, UK: Rowman \& Littlefield. 
Scheerens, J. (1990). School effectiveness and the development of process indicators of school functioning. School Effectiveness and School Improvement, 1, 61-80.

Scheerens, J. (Ed.) (2009). Informal learning of active citizenship at school. An international comparative study in seven European countries. Dordrecht, The Netherlands: Springer-Verlag.

Scheerens, J. (2011). Indicators on informal learning for active citizenship at school. Educational Assessment, Evaluation and Accountability, 23(3), 201-222.

Scheerens, J., \& Bosker, R. J. (1997). The foundations of educational effectiveness. Oxford, UK: Pergamon.

Schereens J., Glas, C., \& Thomas, M. S. (2003). Educational evaluation, assessment, and monitoring. A systematic approach. London, UK/New York, NY, USA: Taylor \& Francis.

Scheufele, D. A., Nisbet, M. C., \& Brossard, D. (2003). Pathways to political participation? Religion, communication contexts, and mass media. International Journal of Public Opinion Research, 15(3), $300-324$.

Schlozman, K., Verba, S., \& Brady, H. (2012). The Unheavenly Chorus: Unequal Political Voice and the broken promise of American democracy. Princeton, NJ, USA: Princeton University Press.

Schulz, W. (2005). Political efficacy and expected political participation among lower and upper secondary students. Paper presented at the ECPR General Conference, Budapest, September 8-10, 2005. Retrieved from http://iccs.acer.edu.au/uploads/File/papers/ECPR2005_SchulzW_ EfficacyParticipation.pdf.

Schulz, W. (2004). Scaling procedures for Likert-type items on students' concepts, attitudes and actions. In W. Schulz, \& H. Sibberns (Eds.), IEA Civic Education Study: Technical report (pp. 193126). Amsterdam, The Netherlands: International Association for the Evaluation of Educational Achievement (IEA).

Schulz, W., \& Friedman, T. (2011). Scaling procedures for ICCS questionnaire items. In W. Schulz, J. Ainley, J., \& J. Fraillon (Eds.), ICCS 2009 Technical Report (pp. 157-259). Amsterdam, The Netherlands: International Association for the Evaluation of Educational Achievement (IEA).

Schulz, W., Ainley, J., \& Fraillon, J. (2015). Assessing the intended participation of young adolescents as future citizens: Comparing results from five East Asian countries. In: World Education Research Yearbook 2015 (pp. 74-93), London, UK/New York, NY, USA: Routledge.

Schulz, W., Ainley, J., Fraillon, J., Kerr, D., \& Losito, B. (2010a). Initial findings from the International Civic and Citizenship Education Study. Amsterdam, The Netherlands: International Association for the Evaluation of Educational Achievement (IEA).

Schulz, W., Ainley, J., Fraillon, J., Kerr, D., \& Losito, B. (2010b). ICCS 2009 International Report. Civic knowledge, attitudes and engagement among lower secondary school students in thirtyeight countries. Amsterdam, The Netherlands: International Association for the Evaluation of Educational Achievement (IEA).

Schulz, W., Ainley, J., Friedman, T., \& Lietz, P. (2011). ICCS 2009 Latin American Report: Civic knowledge and attitudes among lower secondary students in six Latin American countries. Amsterdam, The Netherlands: International Association for the Evaluation of Educational Achievement (IEA).

Schulz, W., Fraillon, J., \& Ainley, J. (2011). The International Civic and Citizenship Education Study (ICCS). In C. Papanastasiou, T. Plomp , \& E. C. Papanastasiou (Eds.), IEA 1958-2008: 50 years of experiences and memories Volume 1 (pp. 187-200). Nicosia, Cyprus: Cultural Center of the Kykkos Monastery.

Schulz, W., Fraillon, J., Ainley, J., Losito, B., \& Kerr, D. (2008). International Civic and Citizenship Education Study. Assessment framework. Amsterdam, The Netherlands: International Association for the Evaluation of Educational Achievement (IEA).

Schulz, W., Losito, B., \& Kerr, D. (2011). ICCS questionnaire development. In W. Schulz, J. Ainley, J., \& J. Fraillon (Eds.), ICCS 2009 Technical Report (pp. 33-43). Amsterdam, The Netherlands: International Association for the Evaluation of Educational Achievement (IEA). 
Segerberg, A., \& Bennett, W. L. (2011). Social media and the organization of collective action: Using Twitter to explore the ecologies of two climate change protests. The Communication Review, 14(3), 197-215.

Seltzer, J. (1994). Consequences of marital dissolution for children. Annual Review of Sociology, 20, 235-266.

Shahin, J., Woodward, A., \& Terzis, G. (2012). Study on the impact of the crisis on civil society organizations in the EU: Risks and opportunities. Study for the European Economic and Social Committee. Institute for European Studies, Vrije Universiteit Brussels (IES-VUB), Belgium.

Sherrod, L., Torney-Purta, J., \& Flanagan, C. (Eds.). (2010). Handbook on civic engagement in youth. Hoboken, NJ, USA: John Wiley and Sons.

Shulman, L. S. (1987). Knowledge and teaching: Foundations of the new reform. Harvard Educational Review, 57(1), 1-22.

Shulman, L. S. (1986). Those who understand: Knowledge growth in teaching. Educational Researcher, 15(2), 4-31.

Sirin, S. (2005). Socioeconomic status and academic achievement: A meta-analytic review of research. Review of Educational Research, 75(3), 417- 453.

Smidt, C. (1999). Religion and civic engagement: A comparative analysis. The Annals of the American Academy of Political and Social Science, 565(1), 176-192.

Smith, P. K. (2004). Bullying: Recent developments. Child and Adolescent Mental Health, 9(3), 98-103.

Smith, P. K., Morita, Y., Junger-Tas, J., Olweus, D., Catalano, R., \& Slee, P. (1998). The nature of school bullying: A cross-national perspective. London, UK: Routledge.

Smith, P.K., \& S. Shu (2000). What good schools can do about bullying: Findings from a survey in English schools after a decade of research and action. Childhood, 7(2), 193-212.

Soysal, Y. N. (1994). Limits of citizenship: Migrants and postnational membership in Europe. Chicago, IL, USA: Chicago University Press.

Spannring, R., Wallace, C., \& Datler, G. (2008). What leads young people to identify with Europe? An exploration of the impact of exposure to Europe and political engagement on European identity among young Europeans. Perspectives on European Politics and Society, 9(4), 480-498.

Stanat, P., \& Christensen, G. (2006). Where immigrant students succeed: A comparative review of performance and engagement in PISA 2003. Paris, France: OECD Publications.

Stoll, L. (1999). School culture: Black hole or fertile garden for school improvement? In J. Prosser (Ed.), School culture (British Educational Management series). London, UK: SAGE Publications.

Stolle, D., with Lewis, J. (2002). Social capital: An emerging concept. In B. Hobson, J. Lewis, \& B. Siim (Eds.), Contested concepts in gender and European social politics (pp. 195-229). Cheltenham, UK: Edward Elgar Press.

Stolle, D., Hooghe, M., \& Micheletti, M. (2005). Politics in the supermarket: Political consumerism as a form of political participation. International Political Science Review, 26(3), 245-269.

Stolp, S. (1994). Leadership for school culture (ERIC Document Reproduction Service No. 91). East Lansing, MI, USA: National Center for Research on Teacher Learning.

Storm, I. (2015). Civic engagement in Britain: The role of religion and inclusive values. European Sociological Review, 31(1), 14-29.

Strayer, J. (1987). Affective and cognitive perspectives on empathy. In N. Eisenberg, \& J. Strayer (Eds.), Empathy and its development (pp. 218-244). Cambridge, UK: Cambridge University Press.

Thapa, A., Cohen, J., Guffey, S., \& Higgins-D’Alessandro, A. (2013). A review of school climate research. Review of Educational Research, 83(3), 357-385.

Torgler, B., \& Valev, N. T. (2004). Corruption and age (working Paper No. 2004-24). Basel, Switzerland: Center for Research in Economics, Management and the Arts. 
Torney, J., Oppenheim, A. N., \& Farnen, R. F. (1975). Civic education in ten countries: An empirical study. New York, NY, USA: John Wiley and Sons.

Torney-Purta, J. (2009). International psychological research that matters for policy and practice. American Psychologist, 64, 822-837.

Torney-Purta, J., \& Barber, C. (2004). Democratic school participation and civic attitudes among European adolescents: Analysis of data from the IEA Civic Education Study. Strasbourg, France: Council of Europe, DGIV/EDU/CIT (2004) 40.

Torney-Purta, J., \& Schwille, J. (2011). The IEA Studies in civic education: their history. In C. Papanastasiou, T. Plomp , \& E. C. Papanastasiou (Eds.), IEA 1958-2008: 50 years of experiences and memories Volume 1 (pp. 97-113). Nicosia, Cyprus: Cultural Center of the Kykkos Monastery.

Torney-Purta, J., Lehmann, R., Oswald, H., \& Schulz, W. (2001). Citizenship and education in twenty-eight countries. Amsterdam, The Netherlands: International Association for the Evaluation of Educational Achievement (IEA).

Torney-Purta, J., Schwille, J., \& Amadeo, J. A. (1999). Civic education across countries: Twenty-four case studies from the IEA Civic Education Project. Amsterdam, The Netherlands: International Association for the Evaluation of Educational Achievement (IEA).

Torrance, D. (2013). Distributed leadership: Still in the gift of the headteacher. Scottish Educational Review 45(2), 50-63.

Torres, C. A. (2002). Globalization, education, and citizenship: Solidarity versus markets? American Educational Research Journal, 39(2), 363-378.

Trafford, B. (2003). School councils, school democracy, school improvement: Why, what, how. Leicester, UK: Secondary Heads Association.

Transparency International. (2014). Corruption perceptions index 2014. Berlin, Germany: Author.

Travers, K. J., \& Westbury, I. (1989). The IEA Study of Mathematics I: Analysis of mathematics curricula. Oxford, UK: Pergamon Press.

Travers, K. J., Garden, R. A., \& Rosier, M. (1989). Introduction to the study. In: D. A. Robitaille, \& R. A. Garden (Eds.), The IEA Study of Mathematics II: Contexts and outcomes of school mathematics curricula. Oxford, UK: Pergamon Press.

Ttofi, M., \& Farrington, D. P. (2011). Effectiveness of school-based programs to reduce bullying: A systematic and meta-analytic review. Journal of Experimental Criminology, 7, 27-56.

UNESCO (2012a). Education for sustainable development sourcebook. Paris, France: Author.

UNESCO (2012b). International standard classification of education ISCED 2011. Paris, France: UNESCO-UIS.

UNESCO (2015). Global citizenship education: Topics and learning objectives. Paris, France: Author.

United Nations (1948). The universal declaration of human rights. New York, NY, USA: Author. Retrieved from http://www.un.org/en/universal-declaration-human-rights/index.html

United Nations (2012). Resolution of the General Assembly on “Education for Democracy”. A/67/L.25. Retrieved from http://www.un.org/en/globalissues/democracy/documents.shtml.

United Nations. (2015). Transforming our world: the 2030 Agenda for Sustainable Development. Resolution adopted by the General Assembly on 25 September 2015. Retrieved from https:// sustainabledevelopment.un.org/post2015/transformingourworld.

United Nations Development Programme. (2004). La democracia en América Latina: hacia una democracia de ciudadanos y ciudadanas [Democracy in Latin America: Towards democracy for citizens]. New York, NY, USA/Buenos Aires, Argentina: Author.

Van Deth, J. W. (2014). A conceptual map of political participation. Acta Politica, 49, 349-367.

Van Deth, J. W., Maraffi, M., Newton, K., \& Whiteley, P. F. (1999). Social capital and European democracy. London, UK/New York, NY, USA: Routledge. 
Van Houtte, M. (2005). Climate or culture? A plea for conceptual clarity in school effectiveness research. School Effectiveness and School Improvement, 16(1), 71-89.

Verba, S., Schlozman, K. L., \& Brady, H. E. (1995). Voice and equality. Cambridge, MA, USA: Harvard University Press.

Verkuyten, M., \& Thijs, J. (2002). Racist victimization among children in the Netherlands: The effect of ethnic group and school. Ethnic and Racial Studies, 25(2), 310-331.

Veugelers, W. (2007). Creating critical-democratic citizenship education. Compare, 37(1), 105-119.

Veugelers, V. (2011). The moral and the political in global citizenship: appreciating differences in education. Globalisation, Societies and Education, 9(3-4), 473-485.

Vollebergh, W. A. M., Iedema, J., \& Raaijmakers, Q. A. W. (2001) Intergenerational transmission and the formation of cultural orientations in adolescence and young adulthood. Journal of Marriage and Family, 63(4): 1185-1198.

Wade, A., \& Beran, T. (2011). Cyberbullying: The new era of bullying. Canadian Journal of School Psychology, 26, 44-61.

Walker, D. A. (1976). The IEA Six Subject Study: An empirical study of education in twenty-one countries. Stockholm, Sweden/New York, NY, USA: Almqvist and Wiksell International/ John Wiley and Sons.

Wang, M.-T., \& Degol, J. L. (2015). School climate: a review of the construct, measurement and impact on student outcomes. Educational Psychology Review, 27, 1-38. doi 10.1007/s10648-0159319-1.

Webster, B. J., \& Fisher, D. L. (2000). Accounting for variation in science and mathematics achievement: A multilevel analysis of Australian data from the Trends in International Mathematics and Science Study (TIMSS). School Effectiveness and School Improvement, 11(3), 339-360.

Westheimer, J., \& Kahne, J. (2004). What kind of citizen? The politics of educating for democracy. American Educational Research Journal, 41(2), 237-269.

White, K. R. (1982).The relation between socioeconomic status and educational achievement. Psychological Bulletin, 91(3), 461-481.

Williams, J. H. (2005). Cross-national variations in rural mathematics achievement: A descriptive overview. Journal of Research in Rural Education, 20(5), 1-18.

Willms, J. D., Friesen, S., \& Milton, P. (2009). What did you do in school today? Transforming classrooms through social, academic, and intellectual engagement. (First National Report) Toronto, Canada: Canadian Education Association.

Woolcock, M. (2001). The place of social capital in understanding social and economic outcomes. ISUMA Canadian Journal of Policy Research, 2(1), 11-17.

Ziller, C. (2014). Societal implications of antidiscrimination policy in Europe, Research and Politics, 1(3), 1-9.

Zuehlke, O. (2011). Sampling design and implementation. In W. Schulz, J. Ainley, \& J. Fraillon (Eds.), ICCS 2009 Technical Report (pp. 59-68). Amsterdam, The Netherlands: International Association for the Evaluation of Educational Achievement (IEA).

Open Access This chapter is distributed under the terms of the Creative Commons AttributionNonCommercial 4.0 International License (http://creativecommons.org/licenses/by-nc/4.0/), which permits any noncommercial use, duplication, adaptation, distribution and reproduction in any medium or format, as long as you give appropriate credit to the original author(s) and the source, provide a link to the Creative Commons license and indicate if changes were made.

The images or other third party material in this chapter are included in the works Creative Commons license, unless indicated otherwise in the credit line; if such material is not included in the works Creative Commons license and the respective action is not permitted by statutory regulation, users will need to obtain permission from the license holder to duplicate, adapt or reproduce the material. 


\section{Appendices}

\subsection{Appendix A: Institutions and staff}

\section{International study center}

The international study center is located at the Australian Council for Educational Research (ACER). ACER were responsible for designing and implementing the study in close cooperation with LPS (Laboratorio di Pedagogia Sperimentale at the Roma Tre University, Rome, Italy), the IEA Data Processing and Research Center (DPC) in Hamburg, and the IEA Secretariat in Amsterdam, the Netherlands.

\section{Staff at ACER}

Wolfram Schulz, research director

Julian Fraillon, coordinator of test development

John Ainley, project researcher

Tim Friedman, project researcher

Nora Kovarcikova, project researcher

Naoko Tabata, project researcher

Judy Nixon, test development

Trisha Reimers, test development

Eveline Gebhardt, data analyst

Louise Ockwell, data analyst

Jorge Fallas, data analyst

Renee Chow, data analyst

\section{Staff at LPS}

Bruno Losito, associate research director

Gabriella Agrusti, project researcher

Elisa Caponera, project researcher

Paola Mirti, project researcher

Valeria Damiani, project researcher

Francesco Agrusti, project researcher

Alessandro Sanzo, project researcher

\section{International Association for the Evaluation of Educational Achievement (IEA)}

IEA provides overall support in coordinating ICCS. The IEA Secretariat in Amsterdam, the Netherlands, were responsible for the study membership, translation verification, and quality control monitoring, and publication. The IEA Data processing and Research Center (DPC) in Hamburg, Germany, is the International Coordinating Center for the study and were responsible for overall coordination of study activities, sampling procedures and the processing of data. 


\section{Staff at the IEA Secretariat}

Dirk Hastedt, executive director

Paulína Koršňáková, director of the IEA Secretariat

Gabriela Noveanu, senior researcher

Gillian Wilson, publications officer

Roel Burgers, financial manager

Isabelle Gemin, financial assistant

\section{Staff at the IEA Data Processing and Research Center (DPC)}

Heiko Sibberns, director

Ralph Carstens, ICCS project director

Marta Kostek, ICCS project coordinator

Falk Brese, ICCS international data manager

Hannah Köhler, ICCS deputy international data manager

Sabine Tieck, researcher (sampling)

Sabine Weber, researcher (sampling)

Diego Cortes, researcher (sampling)

Olaf Zuehlke, research analyst (sampling)

Duygu Savasci, research analyst (sampling)

Dirk Oehler, research analyst

Christine Busch, research analyst

Tim Daniel, research analyst

Michael Jung, research analyst

Alena Becker, research analyst

Parisa Aghakasiri, research analyst

Kamil Kowolik, research analyst

Svetoslav Velkov, research analyst

Ekaterina Mikheeva, research analyst

Clara Beyer, research analyst

Maike Junod, programmer

Limiao Duan, programmer

Deepti Kalamadi, programmer

Bettina Wietzorek, meeting and seminar coordinator

\section{ICCS 2016 project advisory committee (PAC)}

The ICCS 2016 PAC has, from the beginning of the project, advised the international study center and its partner institutions during regular meetings.

\section{PAC members}

Erik Amnå, Örebro University, Sweden

Cristián Cox, Diego Portales University, Chile

Babara Malak-Minkiewicz, the Netherlands

Judith Torney-Purta, University of Maryland, United States

Wiel Veugelers, The University of Humanistic Studies Utrecht, Netherlands

\section{ICCS 2016 sampling referee}

Marc Joncas from Statistics Canada in Ottawa is the sampling referee for the study. He has provided invaluable advice on all sampling-related aspects of the study. 


\section{ICCS 2016 National Research Coordinators (NRCs)}

The national research coordinators (NRCs) played a crucial role in the study's development. They provided policy- and content-oriented advice on developing the instruments and were responsible for the implementation of ICCS 2016 in the participating countries.

Belgium (Flemish)

Ellen Claes

University of Leuven, Centre for Citizenship and Democracy

\section{Bulgaria}

Svetla Petrova

Center for Control and Assessment of the Quality in School Education

Chile

Elisa Salinas Valdivieso

Education Quality Assurance Agency

Chinese Taipei

Meihui Liu

National Taiwan Normal University

\section{Colombia}

Andrés Gutiérrez

Carolina Lopera

Colombian Institute for the Assessment of Education (ICFES)

\section{Croatia}

Ines Elezović

Department for Quality Assurance in Education, National Centre for External Evaluation of Education

\section{Denmark}

Jens Bruun

Danish School of Education, Aarhus University

\section{Dominican Republic}

Massiel Cohen

Ancell Scheker

Ministry of Education

\section{Estonia}

Anu Toots

School of Governance, Law and Society, Tallinn University

\section{Finland}

Jouko Mehtäläinen

Finnish Institute for Educational Research, University of Jyväskylä

\section{Germany (North Rhine-Westphalia)}

Hermann Josef Abs

University of Duisburg-Essen 


\section{Hong Kong SAR}

Wai Man Lam

Centre for Civil Society and Governance, The University of Hong Kong

Italy

Laura Palmerio

INVALSI

\section{Latvia}

Ireta Chekse

University of Latvia

\section{Lithuania}

Justè Navickaitè

National Examination Center

Malta

Frank Fabri

Karen Grixti

Directorate for Research and Policy Development

\section{Mexico}

María Antonieta-Díaz Gutiérrez.

National Institute for the Evaluation of the Education (INEE, México)

\section{The Netherlands}

Anke Munniksma

University of Amsterdam

\section{Norway}

Lihong Huang

NOVA - Norwegian Social Research, Oslo and Akershus University College of Applied Sciences

\section{Peru}

Liliana Miranda Molina

Office of Educational Quality Measurement

\section{Republic of Korea}

Geun Young Chang

National Youth Policy Institute (NYPI)

Tae-Jun Kim

Korean Educational Development Institute (KEDI)

\section{Russian Federation}

Petr Polozhevets

Publishing House "Teachers Weekly"

\section{Slovenia}

Eva Klemencic

Educational Research Institute

\section{Sweden}

Ellen Almgren

Swedish National Agency for Education 


\subsection{Appendix B: Described proficiency levels}

\section{Level 3: 563 score points and above}

Students working at Level 3 make connections between the processes of social and political organization and influence, and the legal and institutional mechanisms used to control them. They generate accurate hypotheses on the benefits, motivations, and likely outcomes of institutional policies and citizens' actions. They integrate, justify, and evaluate given positions, policies or laws based on the principles that underpin them. Students demonstrate familiarity with broad international economic forces and the strategic nature of active participation.

Students working at Level 3, for example:

- Identify likely strategic aims of a program of ethical consumption

- Suggest mechanisms by which open public debate and communication can benefit society

- Suggest related benefits of widespread cognitive intercultural understanding in society

- Justify the separation of powers between the judiciary and the parliament

- Relate the principle of fair and equal governance to laws regarding disclosure of financial donations to political parties

- Evaluate a policy with respect to equality and inclusiveness

- Identify the main feature of free market economies and multinational company ownership.

\section{Level 2: 479 to 562 score points}

Students working at Level 2 demonstrate familiarity with the broad concept of representative democracy as a political system. They recognize ways in which institutions and laws can be used to protect and promote a society's values and principles. They recognize the potential role of citizens as voters in a representative democracy, and they generalize principles and values from specific examples of policies and laws (including human rights). Students demonstrate understanding of the influence that active citizenship can have beyond the local community. They generalize the role of the individual active citizen to broader civic societies and the world.

Students working at Level 2, for example:

- Relate the independence of a statutory authority to maintenance of public trust in decisions made by the authority

- Generalize the economic risk to developing countries of globalization from a local context

- Identify that informed citizens are better able to make decisions when voting in elections

- Relate the responsibility to vote with the representativeness of a democracy

- Describe the main role of a legislature/parliament

- Define the main role of a constitution

- Relate the responsibility for environmental protection to individual people.

Level 1: 395 to 478 score points

Students working at Level 1 demonstrate familiarity with equality, social cohesion, and freedom as principles of democracy. They relate these broad principles to everyday examples of situations in which protection of or challenge to the principles are demonstrated. Students also demonstrate familiarity with fundamental concepts of the individual as an active citizen: they recognize the necessity for individuals to obey the law; they relate individual courses of action to likely outcomes; and they relate personal characteristics to the capacity of an individual to effect civic change.

Students working at Level 1, for example:

- Relate freedom of the press to the accuracy of information provided to the public by the media

- Justify voluntary voting in the context of freedom of political expression

- Identify that democratic leaders should be aware of the needs of the people over whom they have authority

- Justifies voluntary voting in the context of freedom of political expression

- Recognize that the UN Universal Declaration of Human Rights is intended to apply to all people

- Generalize about the value of the internet as a communicative tool in civic participation

- Recognize the civic motivation behind an act of ethical consumerism. 


\subsection{Appendix C: Example test items}

This appendix contains nine examples of test items that were used in the ICCS 2009 Main Survey which cover a range of content domains. For each example item the following summary information is included:

Item ID: $\quad$ The unique item identifier used in the test and reported in the ICCS 2009 International Database.

Key: $\quad$ For multiple choice items the key is the correct response. The key is numbered 1.2. 3 or 4 to indicate the ordinal position of the correct response in the set of four response options.

Content domain: The content domain reference to the ICCS 2009 Assessment Framework ${ }^{15}$.

Content sub domain: The content sub domain reference to the ICCS 2009 Assessment Framework

Content aspect: $\quad$ The content aspect reference to the ICCS 2009 Assessment Framework (where applicable).

Cognitive domain: The cognitive domain reference to the ICCS 2009 Assessment Framework.

ICCS level: $\quad$ The proficiency level on the ICCS scale in which the item is located.

15 Schulz, W., Ainley, J., Fraillon, J., Losito, B., \& Kerr, D. (2008). International Civic and Citizenship Education Study Assessment Framework. Amsterdam, the Netherlands: International Association for the Evaluation of Educational Achievement. 


\begin{tabular}{|c|c|c|c|c|}
\hline Item ID & Cl2MLM1 & Max Score & Key & 3 \\
\hline $\begin{array}{l}\text { Content } \\
\text { domain }\end{array}$ & Civic principles & & & \\
\hline $\begin{array}{l}\text { Content sub } \\
\text { domain }\end{array}$ & Equity & Content aspect & $\mathrm{N} / \mathrm{A}$ & \\
\hline $\begin{array}{l}\text { Cognitive } \\
\text { domain }\end{array}$ & Reasoning and & analyzing & & \\
\hline ICCS Level & 1 & & & \\
\hline
\end{tabular}

In $<$ Zedland $>$, there is a minority group of people whose main language is different from the official language of the country. The group has its own schools where the children are taught and learn only in their own traditional language.

The government of $<$ Zedland $>$ decides that all schools should teach all children only in the official language of the country. The government makes this decision because it believes it will help the children of the minority group.

\section{Cl2MLM1}

Q Which of the following arguments best supports the government's decision?

It will stop the children from speaking their own traditional language at home.

It will make school more interesting to the children.

It will give the children a greater chance to participate fully in the wider community.

It will help the children learn their traditional language at home more easily. 


\begin{tabular}{|c|c|c|c|c|c|}
\hline Item ID & Cl2MLM2 & Max Score & 1 & Key & 3 \\
\hline $\begin{array}{l}\text { Content } \\
\text { domain }\end{array}$ & Civic principles & & & & \\
\hline $\begin{array}{l}\text { Content sub } \\
\text { domain }\end{array}$ & Equity & Conten & spect & N/A & \\
\hline $\begin{array}{l}\text { Cognitive } \\
\text { domain }\end{array}$ & Reasoning and & analyzing & & & \\
\hline ICCS Level & 3 & & & & \\
\hline
\end{tabular}

\section{CI2MLM2}

Q What is the best argument against the government's decision?

The subjects schools teach should not be influenced by governments.

Governments should accept the need for more than one official language.

Governments have a responsibility to protect the cultures of minority groups.

The children of the minority group may complain about learning the official language. 


\begin{tabular}{|c|c|c|c|c|c|}
\hline Item ID & $\mathrm{Cl} 2 \mathrm{RDM} 2$ & Max Score & 1 & Key & 4 \\
\hline
\end{tabular}

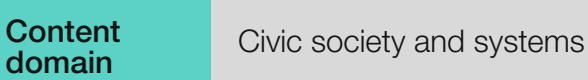

Civic society and systems

Content sub State institutions Content aspect Legislatures/parliaments
domain

domain

Reasoning and analyzing

Cognitive

domain

Reasoning and analyzing

ICCS Level

3

In most countries, one group of people makes laws in parliament. Another group of people applies the laws in the courts.

\section{Cl2RDM2}

Q What is the best reason for having this system?

It allows many people to make changes to laws.

It makes the legal system easy to understand for ordinary citizens.

It means that laws can be kept secret until they are applied in the courts.

It means that no one group has all the power over laws. 


\begin{tabular}{|l|l|l|l|}
\hline Item ID & Cl2TGM1 & Max Score & 1 \\
\hline $\begin{array}{l}\text { Content } \\
\text { domain }\end{array}$ & Civic society and systems & \\
\hline $\begin{array}{l}\text { Content sub } \\
\text { domain }\end{array}$ & Citizens & Content aspect & Rights/responsibilities \\
\hline $\begin{array}{l}\text { Cognitive } \\
\text { domain }\end{array}$ & Reasoning and analyzing \\
\hline ICCS Level & 3 \\
\hline
\end{tabular}

Governments keep records of their activities, decisions, and the information they use to make their decisions.

Some countries have laws that allow people to look at many of these government records.

\section{Cl2TGM1}

Q Why is it important in a democracy for people to be able to look at government records?

It proves to people that the government's decisions are right.

It allows people to make informed judgments about the government's decisions.

$\square$ It means that the government will only make decisions that everyone agrees with.

$\square$ It stops people from criticizing decisions made by the government. 


Item ID CI2TGM2 $\quad$ Max Score 112

\section{Content $\quad$ Civic society and systems
domain}

Content sub State institutions Content aspect Governments

domain

Cognitive
domain

ICCS Level 2

Most countries have laws that allow their government to keep some records secret.

\section{Cl2TGM2}

Q Which of the following records would a government most likely want to keep secret?

statistics showing the amount of money spent on hospitals

plans about how to defend the country from attack

the number of people allowed to immigrate into the country

the names of ambassadors from other countries 


\begin{tabular}{|c|c|c|c|c|c|}
\hline Item ID & Cl128M1 & Max Score & 1 & Key & 4 \\
\hline
\end{tabular}

Content $\quad$ Civic society and systems
domain

Content sub State institutions Content aspect Legislatures/parliaments
domain

Cognitive

domain

Knowing

ICCS Level

2

Cl128M1

Q A country's constitution contains ...

statements about current relations with neighboring countries.

$\square$ statements made by the $<$ Prime Minister $>$ to the national legislature.

$\square$ statements made by the political parties to their supporters.

$\square$ statements of principle establishing the system of government and laws. 


\begin{tabular}{l|l|l|l|l}
\hline Item ID & Cl2DCM1 & Max Score & 1 & Key
\end{tabular}

Content $\quad$ Civic identities
domain

Content sub Civic self-image Content aspect N/A
domain

Cognitive
domain

ICCS Level 1

$<$ Female Name $>$ has been asked to be the leader of her local volunteer environmental protection group.

\section{Cl2DCM1}

Q What does $<$ Female Name $>$ most need to understand about herself to decide whether the group would benefit from her leadership?

how good she is at avoiding criticism

how she can make everyone in the group like her

whether her abilities as a leader match the needs of the members of the group

$\square$ whether she can make sure that everyone in the group always agrees with her. 


\begin{tabular}{|c|c|c|c|c|}
\hline Item ID & Cl2PFM1 & Max Score & Key & 2 \\
\hline $\begin{array}{l}\text { Content } \\
\text { domain }\end{array}$ & Civic principles & & & \\
\hline $\begin{array}{l}\text { Content sub } \\
\text { domain }\end{array}$ & Equity & Content aspect & $\mathrm{N} / \mathrm{A}$ & \\
\hline $\begin{array}{l}\text { Cognitive } \\
\text { domain }\end{array}$ & Reasoning and & analyzing & & \\
\hline ICCS Level & 1 & & & \\
\hline
\end{tabular}

A new group of people, $<$ Group A $>$, have come to live in $<$ Zedtown $>$. They have different cultural traditions to the people already living in $<$ Zedtown $>$. They want to celebrate one of their traditional festivals in the town square. The majority group in $<$ Zedtown $>$ does not want the people in $<$ Group $A>$ to hold their celebration in the town square.

The democratically elected leaders of $<$ Zedtown $>$ have given the people in $<$ Group A $>$ permission to hold their celebration, even though the leaders know that this decision will be unpopular with many people in the town.

\section{Cl2PFM1}

Q Which of the following opinions best explains the $<$ Zedtown $>$ leaders' decision to allow the people of $<$ Group A $>$ to hold their celebration?

The majority group in $<$ Zedtown $>$ must be forced to accept the wishes of $<$ Group A $>$.

All cultural groups have the right to express themselves.

The rights of minority groups are more important than the rights of the majority.

The majority group does not have the right to want the celebration to be banned. 


\begin{tabular}{|c|c|c|c|c|c|}
\hline Item ID & Cl2PFM2 & Max Score & 1 & Key & 1 \\
\hline $\begin{array}{l}\text { Content } \\
\text { domain }\end{array}$ & \multicolumn{5}{|c|}{ Civic participation } \\
\hline $\begin{array}{l}\text { Content sub } \\
\text { domain }\end{array}$ & $\begin{array}{l}\text { Community } \\
\text { participation }\end{array}$ & \multicolumn{2}{|c|}{ Content aspect } & $\begin{array}{l}\text { Participati } \\
\text { and sporti }\end{array}$ & $\begin{array}{l}\text { us, cultural, } \\
\text { ations }\end{array}$ \\
\hline $\begin{array}{l}\text { Cognitive } \\
\text { domain }\end{array}$ & \multicolumn{5}{|c|}{ Reasoning and analyzing } \\
\hline ICCS Level & 2 & & & & \\
\hline
\end{tabular}

\section{CI2PFM2}

Q Which action by $<$ Group $A>$ is most likely to help the people in the majority group change their opinion of the suggested celebration?.

invite people from the majority group to discuss the suggested celebration

hold a protest march in the town square

decorate the town square with their cultural symbols

demand that the majority group accept that people in $<$ Group A $>$ have the right to hold their celebration

Open Access This chapter is distributed under the terms of the Creative Commons AttributionNonCommercial 4.0 International License (http://creativecommons.org/licenses/by-nc/4.0/), which permits any noncommercial use, duplication, adaptation, distribution and reproduction in any medium or format, as long as you give appropriate credit to the original author(s) and the source, provide a link to the Creative Commons license and indicate if changes were made.

The images or other third party material in this chapter are included in the works Creative Commons license, unless indicated otherwise in the credit line; if such material is not included in the works Creative Commons license and the respective action is not permitted by statutory regulation, users will need to obtain permission from the license holder to duplicate, adapt or reproduce the material. 
Countries use IEA's

TIMSS and eTIMSS

to measure mathematics

and science achievement

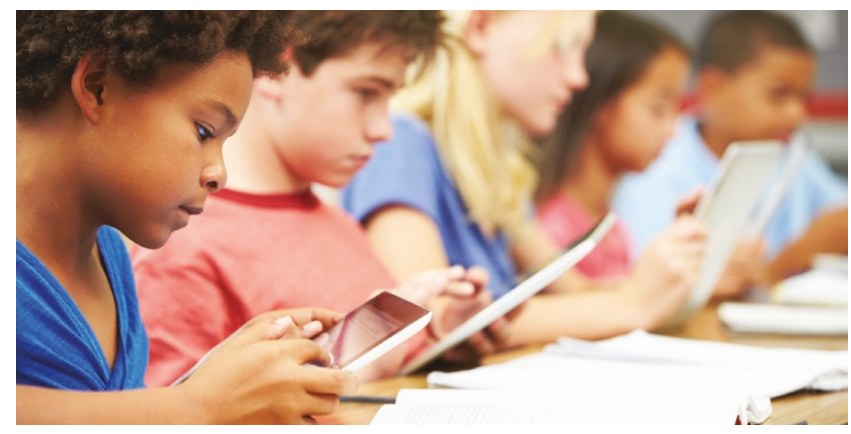

TIMSS MAKE EVIDENCE-BASED DECISIONS TO IMPROVE INSTRUCTION

TIMSS IEA's TIMSS enables countries around the world to evaluate how effective they are in

2019

teaching mathematics and science. The comparative international assessment has

been conducted every four years since 1995 at the fourth and eighth grades, and TIMSS

2019 will mark the seventh TIMSS cycle and 24 years of trend data. Countries have used

TIMSS results to identify gaps in learning resources and opportunities, and to pinpoint areas of weakness and stimulate changes in educational policy. Assessing students at the fourth grade can provide an early warning for necessary curricular reforms, and countries can further monitor the impact of these reforms at the eighth grade.

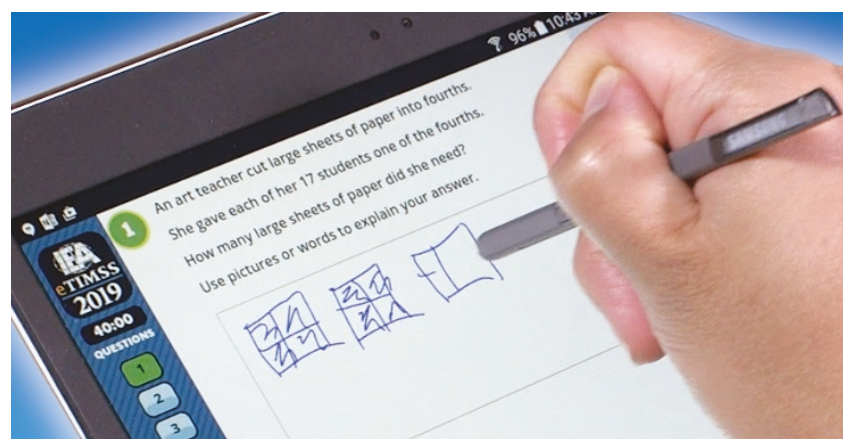

TIMSS reports include data about students' home and school contexts for learning, and the reports allow countries to explore policy relevant variables such as:
System structure and organization
Instructional practices
Technology in the classroom
Student attitudes toward learning

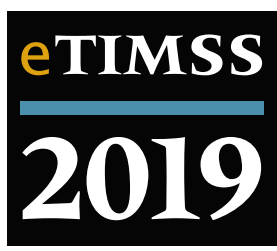

TIMSS ON A TABLET: BRINGING ASSESSMENT INTO A NEW AGE

eTIMSS continues all the benefits of TIMSS in a tablet and stylus format, replicating as much as possible the current TIMSS paper and pencil response experience. Students can use the stylus to draw, erase, and write out computations and other answers. The approach maintains continuity with TIMSS to preserve trend measurement, while keeping costs to a minimum. The format provides interactive assignments that are colorful, animated, and dynamic, delivering an engaging and visually attractive assessment experience that can motivate students.

\section{TIMSS - Trends in International Mathematics and Science Study}

D TIMSS and eTIMSS are projects of IEA (International Association for the Evaluation of Educational Achievement).

The TIMSS projects are directed by the TIMSS \& PIRLS International Study Center at Boston College.

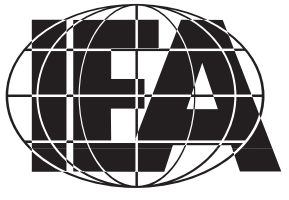

TIMSS \& PIRLS International Study Center

Lynch School of Education, Boston College

For country enrollment, contact: Dr. Paulína Koršňáková, IEA Secretariat-p.korsnakova@iea.nl (www.iea.nl) 